\title{
Overview of 2008 Pesticide Sales in Alberta
}

April 2011 
ISBN (printed): 978-0-7785-9517-5

(On-line edition): 978-0-7785-9518-2

Website Address: http://environment.alberta.ca

More information regarding the "Overview of 2008 Pesticide Sales in Alberta" may be obtained by contacting:
Alberta Environment
$10^{\text {th }}$ Floor 9820 - 106 Street
Edmonton, Alberta T5K 2J6
Phone: (780) 427-9911

This report should be cited as:

Byrtus, G. 2011. Overview of 2008 Pesticide Sales in Alberta. Alberta Environment. Edmonton. 69 pp.

Additional copies of this report may be obtained by contacting:

\author{
Information Centre \\ Alberta Environment \\ Main Floor, Oxbridge Place \\ 9820 - 106th Street \\ Edmonton, Alberta T5K 2J6 \\ Phone: (780) 422-2079 \\ Fax: (780) 427-4407 \\ Email: env.infocent@gov.ab.ca
}




\section{Overview of 2008 Pesticide Sales in Alberta}




\section{EXECUTIVE SUMMARY}

Alberta Environment undertook the collection, consolidation and analysis of pesticide sales data from pesticide vendors in Alberta for the 2008 calendar year. The objective was to document the volume and types of pesticides sold in Alberta, and to prepare a general overview of the sales data in relation to sectors of use, types of use, individual active ingredients, chemical groupings, as well as geographic breakdowns by river basin, municipality and Land Use Framework region. This project is an ongoing survey conducted every five years, with previous reporting undertaken for the years 1993, 1998 and 2003. The 1998 report followed the chemical grouping format used by Quebec in their reporting on pesticide sales in their province, and with the proposed National Pesticide Sales Database. The 2003 and 2008 reports also included individual active ingredient sales information as well as sales by chemical group.

Pesticide sales data was requested from registered wholesale and retail pesticide vendors in Alberta in early 2009, under the authority of the Environmental Protection and Enhancement Act and supporting regulations. Approximately $93 \%$ compliance with the sales data request was obtained. Sales data received was digitized or reformatted to a common database format. Six additional datasets were utilized to assist with sorting and categorizing the sales records by chemical or geographic groups. The datasets were brought into Microsoft Access, where they were linked and various queries were performed. All sales data reported on in this report is based upon pesticide active ingredient, not formulated product.

In 2008, a total of $12476095.8 \mathrm{~kg}$ of pesticide active ingredient (ai) was sold in, or shipped into, Alberta. Pesticides sold into the Agriculture sector accounted for $96.5 \%$ of all pesticides sold, with the Commercial/Industrial sector accounting for $2.7 \%$ of sales, and the Domestic sector accounting for $0.7 \%$ of sales. The types of pesticides sold were predominantly herbicides, at $82.2 \%$. Adjuvants and surfactants made up the next largest category at $12.7 \%$. Insecticides made up $1.9 \%$ of sales, while fungicides made up $3.1 \%$ of sales.

Of the chemical groups, the Phosphonic Acids, Phosphinic Acids group was the largest at 53.2\% of overall sales by active ingredient. Sales in this group were made up primarily of glyphosate. However, in the Domestic sector, the Phenoxy Acids group dominated with $41.5 \%$ of pesticide active ingredient (mainly 2,4-D) sold. 
Looking at geographic distribution of sales by outlet location related to major river drainage, sales in the Oldman River basin were highest overall at $19.6 \%$ of the total active ingredient sold, followed by sales within the Red Deer River basin at $16.6 \%$, and the Battle River basin at $14.5 \%$.

Pesticide sales were also sorted by natural regions. The Grassland Natural Region constituted over $48 \%$ of all pesticide active ingredient sales, mainly in the Dry Mixedgrass and Mixedgrass sub regions. The Parkland Natural Region contained over $36 \%$ of provincial pesticide sales, mainly in the Central Parkland sub-region. The majority of the remainder of pesticide sales was in the Dry Mixedwood sub-region of the Boreal Natural Region.

Geo-administrative regions were also summarized, for use in program planning. Land Use Framework regions (established since the 2003 report) were mapped along with reported sales. The South Saskatchewan region had over $40 \%$ of total sales by active ingredient, with the North Saskatchewan region having just over $25 \%$ of sales.

The municipalities with the highest total pesticide sales were the County of Lethbridge, the MD of Taber, Cypress County, Wheatland County and Vulcan County at over 500,000 kg of active ingredient.

Agricultural pesticide use intensities of over $2.0 \mathrm{~kg}$ ai/ha were estimated for the municipalities of Lethbridge, Taber and Cypress, based upon their cropped acreage and agricultural pesticide sales. This compares to an overall provincial estimated agricultural pesticide use intensity (based upon cultivated land acreage) of $1.02 \mathrm{~kg}$ ai/ha, considerably higher than the $0.78 \mathrm{~kg}$ ai/ha agricultural pesticide use intensity calculated for 2003. Other municipalities with over $300000 \mathrm{~kg}$ ai of agricultural pesticide sales were the Counties of Forty Mile and Vermilion River, as well as Wheatland County, Camrose County, Rocky View County, Kneehill County and Vulcan County. Estimated pesticide use intensities for these municipalities ranged from 1.12 to $1.44 \mathrm{~kg}$ ai/ha. These municipalities may also serve as regional supply centres, so the use intensity estimates may be an overestimation.

The overview of pesticide sales data for Alberta has provided Alberta Environment and other agencies with the background data to enable comparisons to other regions, and to assist in ensuring that Alberta Environment has the appropriate regulatory framework in place for pesticides. The data will also be useful in identifying monitoring priorities for ongoing and upcoming monitoring programs. 
EXECUTIVE SUMMARY i

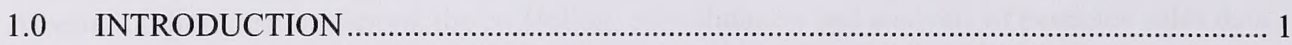

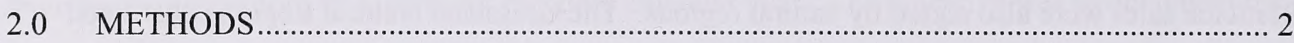

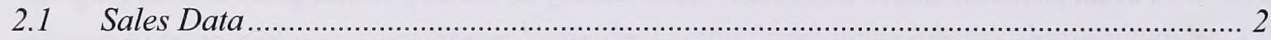

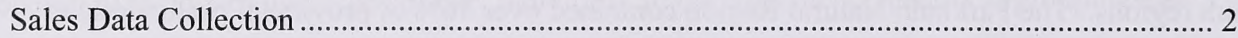

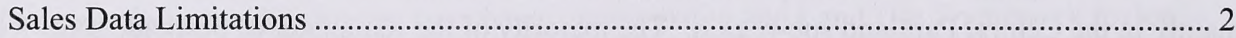

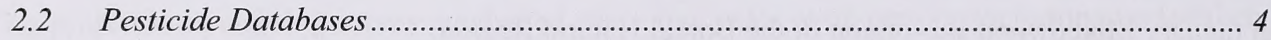

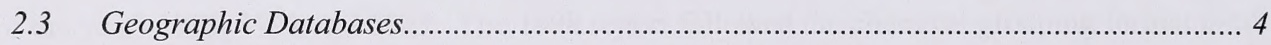

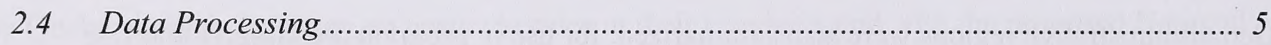

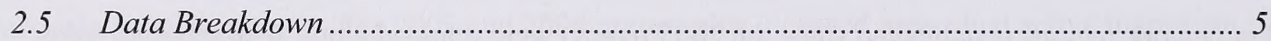

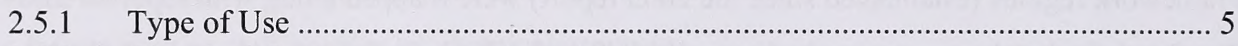

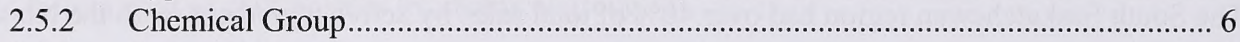

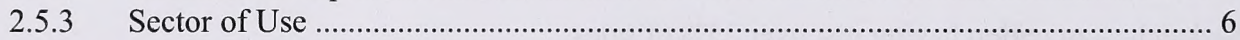

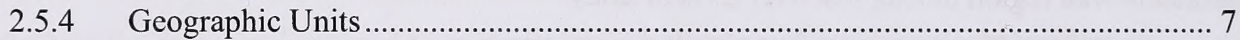

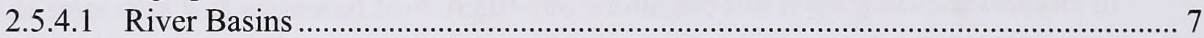

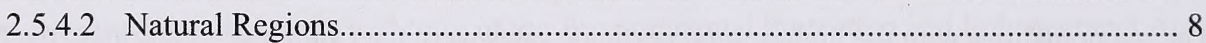

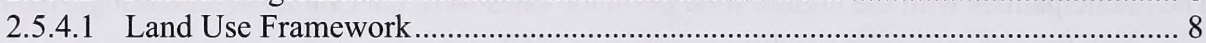

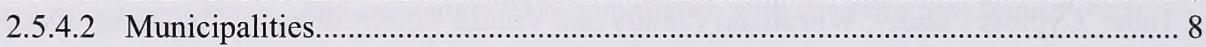

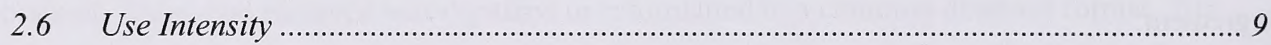

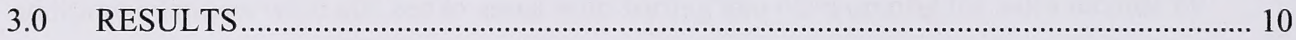

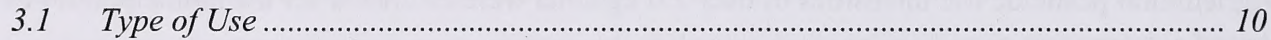

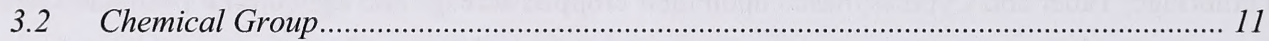

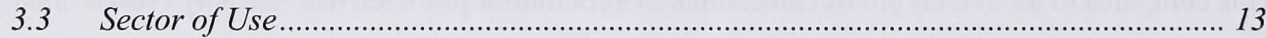

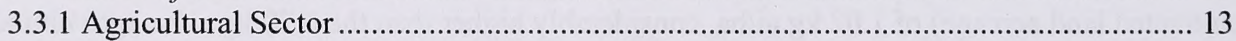

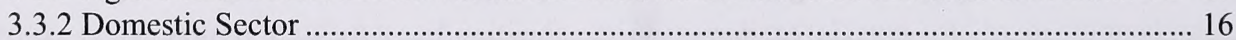

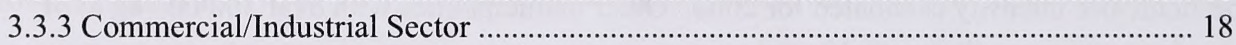

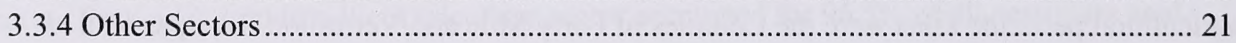

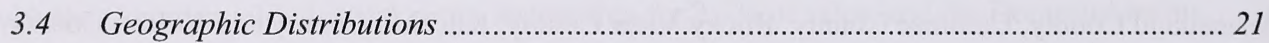

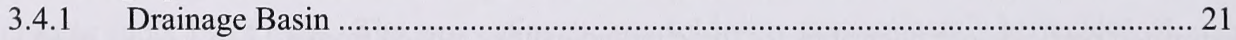

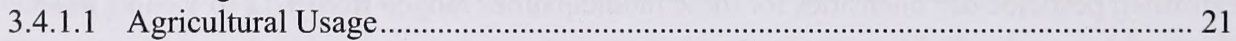

3.4.1.2 Domestic Pesticide Sales by River Basin .......................................................... 22

3.4.2 Pesticide Sales by Natural Region ....................................................................... 22

3.4.3 Pesticide Sales by Municipality .......................................................................... 24

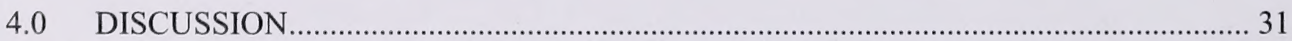

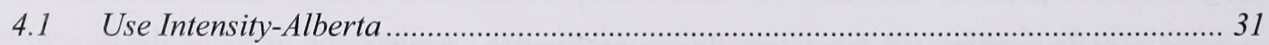

4.2 Pesticide Use - Other Regions .......................................................................... 32

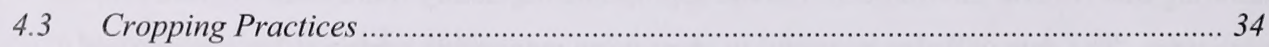

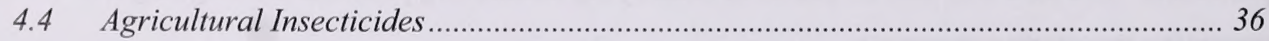

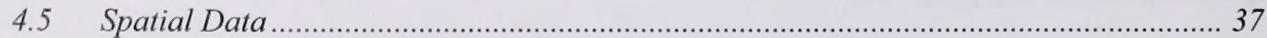




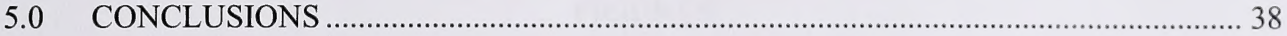

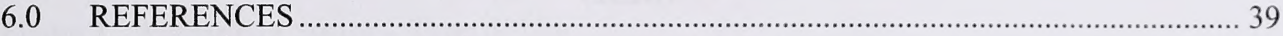

Appendix 1. Chemical Groups and Active Ingredients - 2008 .......................................................... 41

Appendix 2. Alberta (2008) and Quebec (2007) Pesticide Sales by Chemical Group ............................... 48

Appendix 3. Alberta 1998, 2003 and 2008 Pesticide Sales by Active Ingredient ................................... 50

Appendix 4. 2008 Pesticide Sales by Active Ingredient (kg) and River Basin....................................... 59 


\section{TABLES}

Table 1. Pesticide Sales by Type of Use

Table 2. Summary of Pesticide Sales by Chemical Group (all sectors) ................................... 11

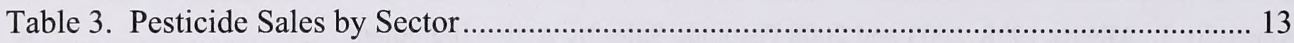

Table 4. Top 15 Agricultural Active Ingredients Sold in 2008, 2003 and 1998 ...................... 14

Table 5. Summary of Agricultural Pesticide Sales by Chemical Group .................................. 15

Table 6. Summary of Domestic Pesticide Sales by Chemical Group - 2008 ........................... 17

Table 7. Top 15 Domestic Active Ingredients Sold in 2008, 2003 and 1998_......................... 18

Table 8. Top 15 Commercial/Industrial Active Ingredients Sold in 2008, 2003 and 1998......... 19

Table 9. Summary of Commercial/Industrial Pesticide Sales by Chemical Group - 2008 ......... 20

Table 10. Agricultural Pesticide Sales (excluding adjuvants) by River Basin .......................... 21

Table 11. Total Domestic Pesticide Sales by River Basin .................................................. 22

Table 12. Total Pesticide Sales by Natural Region ............................................................ 23

Table 13. Total Pesticide Sales by Land Use Framework Region .......................................... 24

Table 14. Breakdown by Municipality of 2006 Crop (ha), Agricultural Pesticide Sales (2008 kg

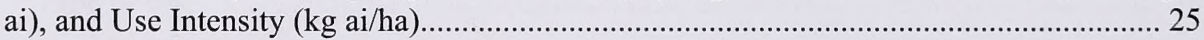

Table 15. Total Pesticide Sales by Municipality (2008) ......................................................... 26

Table 16. Pesticide use comparisons 1988-2008 (excluding adjuvants) ................................... 31

Table 17. Total Pesticide Sales by Type of Use for Alberta and Quebec .................................. 33

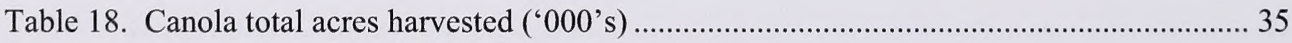




\section{FIGURES}

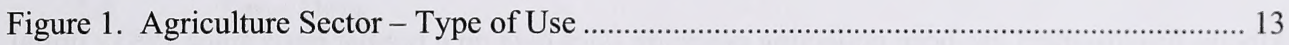

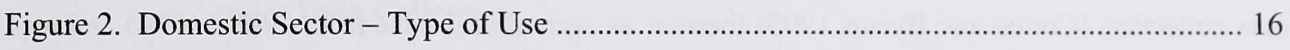

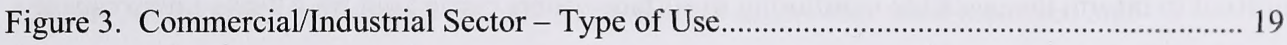

Figure 4. Total Agricultural Pesticide Sales (excluding adjuvants) By River Basin ('000 kg ai) 2008

Figure 5. Total Pesticide Sales by Natural Regions and Subregions (kg ai) - 2008 .................. 28

Figure 6. Total Pesticide Sales by Land Use Framework Region (kg ai) - 2008..................... 29

Figure 7. Total Pesticide Sales by Municipality ('000 kg ai) - 2008 ...................................... 30

Figure 8. Canadian Canola Varieties - Percentage of Seeded Acres (1995-2010) .................... 35

Figure 9. Selected Canola Herbicide Sales (1988-2008)...................................................... 36 


\subsection{INTRODUCTION}

Alberta Environment has been collecting pesticide sales data on a regular basis since 1993. Initial data collection (Cotton and Byrtus 1995) focused on agricultural sales from 1988 to 1993 and was utilized to inform the pesticide monitoring in surface waters carried out by Alberta Environment (Anderson 2005) and Alberta Agriculture and Rural Development in the early 1990's (CAESA 1998). This data was limited to about $50 \%$ of agricultural product sales, and only provided trend information and spatial perspective on certain products. Follow up surveys were done on a five year schedule (in 1998 and 2003), taking a more comprehensive look at pesticide sales in Alberta. Agricultural, domestic, commercial, livestock and structural sectors were surveyed (Byrtus 2000 and 2007). This information was used in the updating of pesticide monitoring programs conducted by Alberta Environment and Alberta Agriculture. Domestic sales data was extracted to provide extensive information on pesticide use by major urban centres in Alberta, and a separate survey of domestic sales was conducted annually following the 2003 survey to inform policy decisions related to domestic pesticide regulatory actions.

For 2008, Alberta Environment undertook its fourth provincial scale review of pesticide sales; using the same data collection and reporting process as was implemented for 1998 and 2003.

The data in this overview will assist Alberta Environment and other provincial and federal agencies in comparisons of pesticide sales/usage information. It will also help to identify monitoring priorities for ongoing monitoring programs and assist in planning for new programs. It will also assist Alberta Environment in ensuring that the appropriate regulatory framework is in place for the pesticides in current use in Alberta.

The specific objectives of this project were:

1. To assemble pesticide sales records representing pesticide use for the calendar year 2008 .

2. To categorize pesticide sales by active ingredient, chemical group, sector of use, and geographic distribution 


\subsection{METHODS}

\section{$2.1 \quad$ Sales Data}

\section{Sales Data Collection}

Alberta Environment maintains a registry of pesticide vendors that retail restricted and commercial registered pesticide products, as well as wholesale distributors of domestic class products. This registry is maintained as a component of the Environmental Management System (EMS), which tracks many of the approvals and registrations issued by Alberta Environment that fall under the Environmental Protection and Enhancement Act (EPEA). Under the authority of this Act and its supporting regulations [Pesticide (Ministerial) Regulation], Alberta Environment can request pesticide sales records from vendors.

A letter was sent out to all registered vendors in Alberta and wholesale distributors in early 2009 requesting pesticide sales in Alberta for the calendar year 2008. Sales data was received throughout 2009 in various formats (hard copy and electronic). Records were received from approximately $93 \%$ of vendors that received sales record requests.

Hard copy records were manually entered into a standardized Excel file, while digital files were converted to the standardized database format, which contains the vendor approval number, product registration number, quantity sold in litres or kilograms, and sector of use. Individual vendor data files were consolidated into a single sales database, which contains almost 83,000 records.

\section{Sales Data Limitations}

\section{Sector Representation}

The data from vendors that are primarily agricultural suppliers may have also contained sales to the landscape industry, the industrial sector, municipal governments, golf courses and other nonagricultural sectors. As a result, the agricultural sector may be slightly over-represented, while the other sectors may be slightly under-represented for those products that have cross-sector utilization. Products that were sold by agricultural retailers, but that were only registered for noncropland uses were classified as sales to the Commercial/Industrial sector. 


\section{Treated Seed}

Sales of fungicide and insecticide treated seed was not targeted in this survey, however some sales records of treated seed were received, converted to a pesticide active ingredient equivalent, and reported. The collection of treated seed sales data was beyond the scope of this project, particularly as seed distribution is often done by seed vendors or seed divisions (not specifically regulated under EPEA) rather than agricultural chemical divisions of the large agricultural input companies. Most of the products used for custom seed treatment at seed cleaning plants were captured in this survey.

\section{Vendor List}

The vendors surveyed were based upon the vendors contacted in 2003, along with an updated list of CropLife certified warehouses, supplied by the Agricultural Warehouse Standards Association. Because of regulatory reform, not all pesticide vendors are registered under EPEA or under the CropLife warehouse program. For example, many of the livestock products have been exempted from vendor registration requirements. Therefore, the livestock product information is not complete. Also, the sales of disinfectants, anti-microbial products and wood preservatives are exempted from requiring a vendor registration, so there is virtually no sales data on those products.

\section{Domestic Products}

The sales records obtained from the agricultural and industrial sectors were considered reasonably accurate in terms of product sold, as they were obtained from systems reporting the point of sale for each product. On the other hand, domestic sales records came from distributors and wholesalers, as well as retail level point of sale, so there is some retail outlet based information, and some records based on sales or shipments within the province. It was assumed that the product shipped to the various domestic retail outlets in 2008 was sold in 2008. Also, some products were shipped through regional distribution systems, and some of that information was not accessed during the 2008 survey.

In the domestic sector, pet care products, spa and pool products, and most wood preservatives (paints and stains) sold in Alberta were not identified in this survey. Some miscellaneous household (indoor) pesticides were also missed in this survey, as they are classified as Schedule 4 
products, which have been exempted from the provincial requirement of authorizations and tracking mechanisms.

\section{Geographic Non-Specific Records}

Some vendors were unable to identify retail outlets for their shipments for a variety of reasons. These sales data were identified as "Alberta", and as a result, would not be included in any geographical breakdown. These records would, however, be included in sector summaries, active ingredient listings, and chemical group summaries.

\subsection{Pesticide Databases}

In order to consolidate pesticide formulation sales information down to active ingredient and to chemical group, two separate databases were also incorporated. The first of the pesticide databases was the pesticide Product database, which was originally obtained from the Pesticide Management Regulatory Agency and updated with pesticide registrations issued up to and including 2008. Registrations for fertilizer-pesticide combinations under the Fertilizer Act were also added to this database. This database has information on the product registration number, active ingredient, guarantee, as well as product name, registration status, etc. This database currently has 17611 records. The second pesticide database used was the Active database, which included active ingredient codes, active ingredient names, chemical family and chemical group. There are a total of 700 records in this database, which also includes disinfectants, antimicrobials and a number of historical active ingredients that are no longer registered or sold in Canada.

\subsection{Geographic Databases}

Four databases were used to identify the geographic distribution of pesticide sales information. The primary database was the Vendor database, which included the vendor registration number, along with the vendor name and location (e.g., city, town, village or hamlet). As a number of sales records were received from vendors that do not require vendor registrations in Alberta (primarily domestic retail vendors), additional vendor numbers were also generated for these. Additional vendor numbers were also generated for all municipalities in Alberta to enable geographic identification of minor vendors, or sales records to end users. Another major database was the City database, which lists all the municipalities in Alberta. Associated with each municipality was the corresponding reference for rural municipality, drainage basin, ecodistrict and Land Use Framework region. Secondary databases included Basin (which cross-referenced 
drainage basin and river basins), and Natural Region (which cross-referenced ecodistrict and natural regions).

\subsection{Data Processing}

The databases and spreadsheets were imported into Microsoft Access for data processing and querying. The databases were linked by related fields to calculate active ingredient values, and subsequent data groupings by chemical group, sector of use, and geographic distribution (see Cotton and Byrtus 1995 for an example of how the calculations were done). Conversion of formulated product sales to $\mathrm{kg}$ of active ingredient (ai) is a common means of expressing pesticide sales/use in other jurisdictions (Gregoire 1997), although actual reporting is sometimes by chemical group or by sector of use instead of by quantities of individual active ingredients.

Assumptions were made with respect to pesticide formulations, such as the specific gravity of all pesticide formulations being 1.0. In 1998, Bacillus formulations were assumed to be $100 \%$ active ingredient. Information on actual percentages of active ingredient on a volume basis was obtained for products sold in 2003 and 2008, so Bacillus formulations are reported here as active ingredient instead of formulated product.

Products that contain more than one active ingredient were assigned an extension number to the PCP (Pest Control Products) number for each of the active ingredients involved in both the sales and product databases. This enabled the use of the existing registration numbers with only a minor modification, and also enabled the software used for the data processing to accurately identify each component of a formulation. However, this resulted in additional records being added to the sales database to account for each active ingredient in a formulation (approximately 20,000 records).

\subsection{Data Breakdown}

In order to simplify the analysis of the data, consolidation of the data based upon type of use, chemical group and sector of use was undertaken.

\subsubsection{Type of Use}

Under the PCP Act, pesticides are classified into 39 product types (herbicides, insecticides, fungicides, etc) of products, which reflect their type of use. For the purpose of this document, the categories have been reduced to 6 primary types of use. All of the active ingredients identified in 
sales made in Alberta in 2008 are included in one of the types of use listed here. For those active ingredients that have multiple types of uses (such as thiram, which is a fungicide and a vertebrate repellent), the product is listed under its primary usage for Alberta. A slightly more detailed breakdown was conducted for Table 16 to align with the breakdown used by Quebec.

- Herbicides and plant growth regulators

- Insecticides, acaracides, repellents,

- Fungicides

- Vertebrate control products and vertebrate repellents

- Adjuvants/surfactants

- Other: (Soil fumigants, wood preservatives, disinfectants, anti-microbials)

As the primary focus of this survey was on traditional pesticides, and not anti-microbial or disinfectant pesticides, sales data from industrial and domestic cleaning agents were not obtained or included, although these are also registered under the PCP Act. Adjuvants and surfactants are widely used in the agricultural industry in Alberta, so these records were included as a separate category.

\subsubsection{Chemical Group}

The chemical groupings used in 2008 are based upon the groups established by the Quebec Ministry of Sustainable Development, Environment and Parks (Dion 2007), in order to enable comparison between the two provincial sales reporting systems. The Alberta surveys conducted in 1998 and 2003 utilized slightly different chemical grouping of pesticides, and comparison of those two year's of data to the 2008 chemical grouping data was not possible. The chemical groupings used in the overview are listed in Appendix 1, along with the active ingredients included in each chemical group.

\subsubsection{Sector of Use}

The intent of categorizing the sales by sector of use was to attempt to differentiate between various sectors and their relative usage of pesticides in Alberta. Initially, it was thought that the sales could be differentiated by product and by the vendor. For products such as home and garden pesticides (Domestic sector), and products used on livestock (Livestock sector), this was relatively easy. However, the sales records indicated that several of the vendors who sell agricultural products primarily, also sold herbicides that were primarily for turf, non-cropland, right of way (ROW) or landscape usage (Commercial/Industrial), and would not be used for 
agricultural production purposes, except perhaps for pasture renovation. These records were categorized as Commercial/Industrial.

Some products have multiple sectoral uses such as agriculture, landscaping or ROW maintenance. As the end use for these products could not be distinguished, these purchases at agricultural vendors have been included under the Agricultural sector. The resulting breakdowns therefore, are simplified and may not accurately reflect actual sectoral usage in Alberta. Some general guidance on sectoral usage was provided by the use patterns identified in the Alberta Agriculture and Food publication "Crop Protection 2008” (AAF 2008).

The sectors of use used in this report include:

- Agricultural (products sold at agricultural outlets and that are approved for on-farm use)

- Domestic (products shipped to or sold at garden centres, hardware stores, etc)

- Commercial/Industrial (includes forestry, ROW, landscaping, golf courses, municipal \& structural)

- $\quad$ Livestock (products sold for use on cattle, horses, sheep, etc)

The structural sector was reported as a separate sector in 2003, but was included in the Commercial/Industrial sector in 2008.

\subsubsection{Geographic Units}

\subsubsection{River Basins}

There are 13 major river basins located within Alberta. Within these river basins are numerous sub-basins or drainage basins, which define the watersheds of major and minor tributaries. In order to assist the interpretation of pesticide monitoring data for Alberta, which is generally reported by major river basin, and sometimes by sub-basin, identification of overall pesticide usage by river basin was required. All of the municipalities in the City database were identified as to their respective sub-basin. The major river basins in Alberta used for this report are based upon Prairie Farm Rehabilitation Administration basins, obtained from Alberta Agriculture and Food (Spiess 2005):

- Athabasca River

- Battle River

- Beaver River

- Bow River
- Hay River

- Milk River

- North Saskatchewan River

- Oldman River 
- Peace River

- $\quad$ Red Deer River
- Sounding Creek

- South Saskatchewan River

\subsubsection{Natural Regions}

There are six major natural regions in Alberta, which contain a total of 21 subregions. To link pesticide sales to the various natural regions in Alberta, each municipality in the City database was allocated to an ecodistrict, which was then linked to the respective natural region in the Natural Region database. The detailed maps used to determine municipality location in relation to ecodistrict were obtained from Alberta Agriculture, Food and Rural Development (AAFRD 2003) and Strong and Thompson (1995). The natural regions identify different ecological zones within Alberta, which are influenced by soil type, climate, physiography, water, fauna, land use, and vegetative cover (Ecological Stratification Working Group 1995). The natural regions of Alberta (updated in 2005) are:

- Grassland

- Parkland

- Canadian Shield
- Foothills

- Rocky Mountain

- Boreal Forest

\subsubsection{Land Use Framework}

The Government of Alberta initiated a new program in 2006 to develop a provincial land use planning blueprint to better manage public and private lands and natural resources to achieve Alberta's long term goals (Land Use Secretariat 2008). The Land Use Framework is intended to balance economic, social and environmental interests competing to utilize the same land base. The provincial framework is broken down into seven regional planning areas, which are aligned by river basins at a broad scale, and by municipal boundaries at the fine scale. The seven planning areas are:

- Lower Athabasca

- Upper Athabasca

- Lower Peace

- Upper Peace
- North Saskatchewan

- Red Deer

- South Saskatchewan

\subsubsection{Municipalities}

There are about 88 municipalities (rural municipalities, cities and national parks) in Alberta. Pesticide sales were allocated to the municipality in which the vendor was located for data analysis by geo-political boundaries. In most situations, agricultural sales made at a vendor 
located in a city were consolidated to the surrounding rural municipality (e.g., Camrose) for the purposes of sub-regional assessments and mapping purposes. The cities of Calgary and Edmonton were identified as distinct municipalities for this report.

\subsection{Use Intensity}

Pesticide use intensity, ( $\mathrm{kg}$ of active ingredient used per hectare of land) is an inexact measurement, but it is often used to compare relative pesticide use between regions or countries with different land areas, or areas with different pesticide usage as a result of different crops requiring different pesticide inputs. It can also be used as a measure of relative pesticide use over time. In this report, pesticide sales by defined geographic area were considered representative of use, and the use intensity was calculated based on the land base for the defined geographic area. Use intensity was calculated based only on agricultural pesticide sales (excluding adjuvants). 


\subsection{RESULTS}

In 2008, a total of $12476095.8 \mathrm{~kg}$ of active ingredient was sold in Alberta. The sales data are broken down as follows.

\subsection{Type of Use}

Herbicides and plant growth regulators (PGR's) made up the majority of pesticides sold in Alberta, at $82.2 \%$ (Table 1). The majority of the increase in sales between 2003 and 2008 was attributed to the increase in sales of herbicides.

Fungicides made up a much smaller proportion (slightly over 3\%), while insecticides made up less than $2 \%$ of sales. In 2003 , insecticides made up a greater proportion of sales as a result of a grasshopper outbreak that year.

Table 1. Pesticide Sales by Type of Use

\begin{tabular}{|l|r|r|r|c|}
\hline Type of Use & $\mathbf{2 0 0 8} \mathbf{~ K g}$ ai & $\mathbf{2 0 0 8 ( \% )}$ & $\mathbf{2 0 0 3} \mathbf{~ k g ~ a i}$ & $\mathbf{2 0 0 3} \%$ \\
\hline \hline Herbicides, PGR's & 10257303.0 & 82.2 & 7158660.3 & 77.3 \\
\hline Insecticides, Acaracides, Repellents & 236168.7 & 1.9 & 433176.1 & 4.7 \\
\hline Fungicides & 388560.4 & 3.1 & 319464.5 & 3.4 \\
\hline $\begin{array}{l}\text { Vertebrate Control Products and } \\
\text { Vertebrate Repellents }\end{array}$ & 12458.4 & 0.1 & 1712.9 & 0.02 \\
\hline Adjuvants and Surfactants & 1580103.8 & 12.7 & 1350159.8 & 14.6 \\
\hline Other & 1501.4 & 0.01 & 1313.9 & 0.01 \\
\hline \hline Total & $\mathbf{1 2 4 7 6 \mathbf { 0 9 5 . 8 }}$ & $\mathbf{1 0 0}$ & $\mathbf{9 2 6 4 4 8 7 . 7}$ & $\mathbf{1 0 0}$ \\
\hline
\end{tabular}

Vertebrate control products and repellents made up a very small percentage of pesticide sales, at $0.1 \%$. These were predominantly products used for controlling Richardson's ground squirrel and pocket gophers.

Adjuvants and surfactants made up the second largest group, in terms of percentage of sales. These compounds are used to enhance the effectiveness of the herbicides on the target weed(s). They have been categorized as a separate type of use, but because they are virtually always used in conjunction with a herbicide, they could be considered a component of the Herbicide group.

The adjuvants used to be predominantly packaged with the herbicides, and issues with leftover adjuvant disposal led to changes in packaging to decouple the adjuvant from the herbicide. Even 
with the decoupling (implemented after the 2003 sales reporting), the adjuvant sales remained high, likely in conjunction with increased herbicide usage.

The "Other" category includes sales for products that do not fit the named categories, and for which only a limited number of sales records were received. This category includes wood preservatives, disinfectants, slimicides and soil fumigants. As the disinfectants and slimicides are exempted under the provincial pesticide regulations, and the focus of the sales survey was primarily on the traditional pesticides, very little information on these products was obtained.

\subsection{Chemical Group}

The sales records were also broken down by chemical group (Table 2), as outlined in Appendix 1. The chemical groups were aligned with the Quebec Ministry of Sustainable Development, Environment and Parks listings (Dion 2007) to enable provincial comparison of sales data (Appendix 2). The chemical group with the largest proportion of sales was the Phosphonic Acids, Phosphinic Acids group at 53.2 \% (up from 38.1\% in 2003), followed by the Phenoxy Acids at $17.1 \%$. The next groups were the Fatty Acids \& Surfactants and Hydrocarbons in the 5$7 \%$ range. These four groups consist of the major herbicides (and adjuvants/surfactants) used in Alberta. The remaining chemical groups were all under 5\%, and 47 of the 54 chemical groups were under $1 \%$ of total sales.

Table 2. Summary of Pesticide Sales by Chemical Group (all sectors)

\begin{tabular}{|l|r|c|}
\hline \hline Chemical Grouping & Kg ai & Percentage \% \\
\hline Phosphonic Acids, Phosphinic Acids & 6633567.6 & 53.2 \\
\hline Phenoxy Acids & 2130654.7 & 17.1 \\
\hline Fatty Acids \& Surfactants & 924680.7 & 7.4 \\
\hline Hydrocarbons & 659521.1 & 5.3 \\
\hline Benzonitriles & 366443.3 & 2.9 \\
\hline Cyclohexanedione oximes & 191948.1 & 1.5 \\
\hline Dinitrobenzenes & 118607.6 & 1.0 \\
\hline Thiocarbamates & 112096.2 & 0.9 \\
\hline Imidazolinones & 111806.9 & 0.9 \\
\hline Aryloxyphenoxyl Acids & 110792.2 & 0.9 \\
\hline Triazoles & 104706.9 & 0.8 \\
\hline Biscarbamates & 102813.6 & 0.8 \\
\hline \hline Benzoic Acid \& Derivatives & 94908.1 & 0.8 \\
\hline Halogenated Organic Acids & 88074.6 & 0.7 \\
\hline Acylureas & 85612.4 & 0.7 \\
\hline Thiophosphates & 85271.0 & 0.7 \\
\hline
\end{tabular}




\begin{tabular}{|l|r|r|}
\hline \hline Pyridines & 72411.4 & 0.6 \\
\hline Inorganics, Other & 64911.7 & 0.5 \\
\hline Dithiophosphates & 57202.3 & 0.5 \\
\hline Urea Derivatives & 47686.2 & 0.4 \\
\hline Azoles, Oxazoles, Thiazoles & 41280.5 & 0.3 \\
\hline Ammoniums, Quaternary & 40722.8 & 0.3 \\
\hline Sulfonylureas & 27844.2 & 0.2 \\
\hline Phthalic Acids & 27137.5 & 0.2 \\
\hline Anilides & 26918.2 & 0.2 \\
\hline Methoxyacrylates & 20532.1 & 0.2 \\
\hline Miscellaneous (Non-Classified) & 18881.7 & 0.2 \\
\hline Carbamates & 15688.9 & 0.13 \\
\hline Morpholines \& Oxathiines & 15453.0 & 0.12 \\
\hline Organic Acids & 12048.4 & 0.10 \\
\hline Chlorotriazines & 10953.3 & 0.09 \\
\hline Nitrobenzenes & 7627.0 & 0.06 \\
\hline Guanidines & 6849.5 & 0.05 \\
\hline Organohalogens & 6106.3 & 0.05 \\
\hline Triazines, Tetrazines & 5919.3 & 0.05 \\
\hline Alcohols & 5853.1 & 0.05 \\
\hline Pyrethroids, Pyrethrins & 5717.9 & 0.05 \\
\hline Inorganic Coppers & 4141.5 & 0.03 \\
\hline Oils, Mineral and Vegetable & 3925.8 & 0.03 \\
\hline Benzamides & 1694.3 & 0.01 \\
\hline Diazines & 1291.1 & 0.01 \\
\hline Pheromones & 1274.0 & 0.01 \\
\hline Phosphates & 1077.6 & 0.01 \\
\hline Organochlorines & 830.3 & 0.01 \\
\hline Phosphoramidothioates & 626.2 & 0.01 \\
\hline Aldehydes & 569.4 & 0.00 \\
\hline Microbials & 420.4 & 0.00 \\
\hline Dithiocarbamates & 392.0 & 0.00 \\
\hline Amides & 270.9 & 0.00 \\
\hline Inorganic Zincs & 179.8 & 0.00 \\
\hline Chromenones & 61.9 & 0.00 \\
\hline Oximes-Carbamates & 24.6 & 0.00 \\
\hline Indanediones & 0.00 \\
\hline Organometallics & 0.00 \\
\hline Total & 100.0 \\
\hline
\end{tabular}


Pesticide sales broken down by sector of use are listed in Table 3. As expected, agricultural use dominates pesticide sales in Alberta at 96.5\%. The next sector was the Commercial/Industrial sector at $2.7 \%$. Domestic pesticide sales made up only $0.7 \%$ of total sales by active ingredient. The Livestock sector made up less than $0.1 \%$ of all sales. The sectoral breakdowns were comparable to 2003 results.

Further breakdown of the sector sales by type of use was conducted to assess if the overall trends in type of use was consistent within each sector. Figures 1-3 show the breakdowns for each sector.

Table 3. Pesticide Sales by Sector

\begin{tabular}{|l|r|c|}
\hline Sector & Kg ai & Percentage (\%) \\
\hline \hline Agriculture & 11985047.9 & 96.1 \\
\hline Commercial/Industrial & 388537.0 & 3.1 \\
\hline Domestic & 89533.6 & 0.7 \\
\hline Livestock & 12977.3 & 0.1 \\
\hline Total & $\mathbf{1 2 4 7 6 0 9 5 . 8}$ & $\mathbf{1 0 0 . 0}$ \\
\hline
\end{tabular}

\subsubsection{Agricultural Sector}

Herbicides made up the majority of pesticide use in the agricultural sector, with $82 \%$ of all sales. Adjuvants were the next highest category, at over $13 \%$ of pesticide use. Adjuvants and surfactants are widely used to enhance the application and effectiveness of herbicides. Insecticide and fungicide use were each below $3 \%$ of agricultural pesticide sales in Alberta.

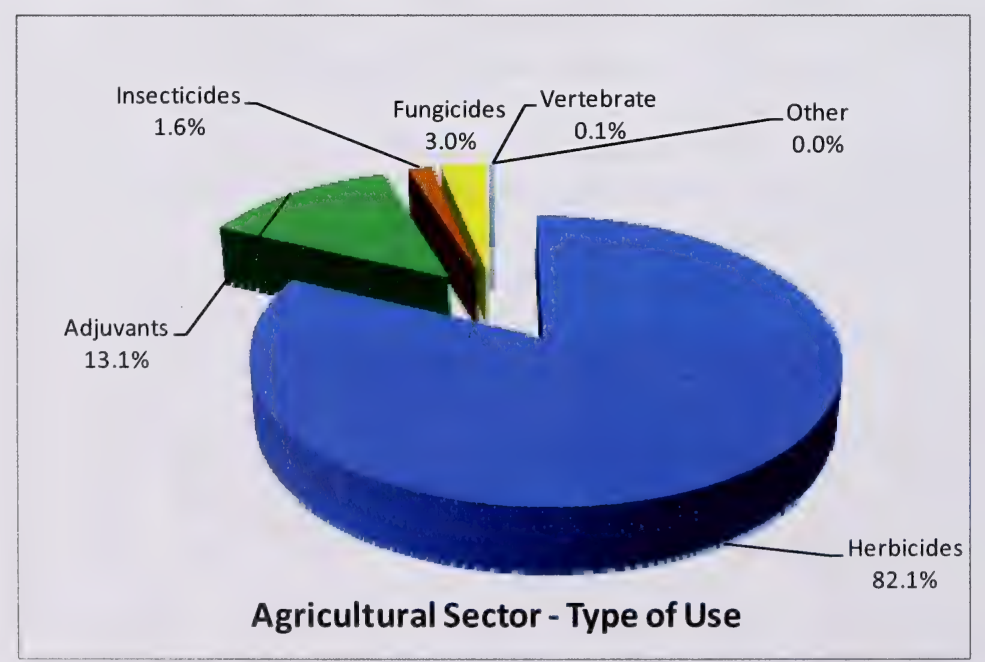

Figure 1. Agriculture Sector - Type of Use 
The top 15 active ingredients sold in the agricultural market in Alberta in 2008 are listed in Table 4, with comparisons to the agricultural sales of those active ingredients in 2003 and 1998.

Overall, there was little change in the order of the top selling products, although some changes were observed as a result of changes in agronomic practices or product replacements. Substantial increases $(>20 \%)$ were observed for glyphosate, 2,4-D and glufosinate. Glufosinate sales increased $270 \%$, while glyphosate sales increased by $85 \%$ over 2003 volumes.

Substantial reductions in sales were again observed for triallate and ethalfluralin, both of which are pre-emergent herbicides used for wild oat control. Further utilization of zero tillage across Alberta (both products require incorporation after application), and continued movement towards herbicide tolerant canola systems, is moving producers away from these products and towards products such as glyphosate and glufosinate for broad spectrum weed control.

The sales of chlorpyrifos (and other insecticides) decreased substantially compared to 2003, as the widespread grasshopper problems experienced in 2003 did not recur in 2008.

Table 4. Top 15 Agricultural Active Ingredients Sold in 2008, 2003 and 1998

\begin{tabular}{|c|c|c|c|c|c|}
\hline Active Ingredient & Usage & $\begin{array}{l}2008 \text { Sales } \\
\text { (kg ai) }\end{array}$ & $\begin{array}{c}2003 \text { Sales } \\
\text { (kg ai) }\end{array}$ & $\begin{array}{l}1998 \text { Sales } \\
\text { (kg ai) }\end{array}$ & $\begin{array}{c}\text { \% Change } \\
\text { (2003 to } \\
2008)\end{array}$ \\
\hline Glyphosate & Herbicide & 6125309.7 & 3333994.5 & 2627599.3 & $+83.7 \%$ \\
\hline MCPA & Herbicide & 1028115.8 & 1096848.9 & 884937.5 & $-6.3 \%$ \\
\hline $2,4-\mathrm{D}$ & Herbicide & 840464.6 & 685294.5 & 674902.6 & $+22.6 \%$ \\
\hline $\begin{array}{l}\text { Petroleum } \\
\text { Hydrocarbon } \\
\text { Blend }\end{array}$ & Adjuvant & 656588.2 & 559728.7 & 368704.3 & $+17.3 \%$ \\
\hline Surfactant Blend & Adjuvant & 401107.1 & 437400.5 & 496177.7 & $-8.3 \%$ \\
\hline Glufosinate & Herbicide & 394652.8 & 106689.6 & 63400.8 & $+270 \%$ \\
\hline Bromoxynil & Herbicide & 330177.1 & 354906.6 & 268105.3 & $-7.0 \%$ \\
\hline $\begin{array}{l}\text { Paraffin Base } \\
\text { Mineral Oil }\end{array}$ & Adjuvant & 188738.7 & 192634.4 & 192708.2 & $-2.0 \%$ \\
\hline $\begin{array}{l}\text { Methylated Canola } \\
\text { Oil }\end{array}$ & Adjuvant & 187385.6 & 0 & 0 & -- \\
\hline Tralkoxydim & Herbicide & 147916.9 & 141226.1 & 126323.5 & $+4.7 \%$ \\
\hline Triallate & Herbicide & 101072.2 & 197221.4 & 693269.3 & $-48.8 \%$ \\
\hline Imazamethabenz & Herbicide & 94004.3 & 138551.4 & 173679.2 & $-32.2 \%$ \\
\hline Ethalfluralin & Herbicide & 82873.7 & 168135.0 & 452294.4 & $-50.7 \%$ \\
\hline Chlorpyrifos & Insecticide & 82725.3 & 197004.7 & 215779.6 & $-58.0 \%$ \\
\hline Dicamba & Herbicide & 77852.0 & 108637.8 & 118739.8 & $-28.3 \%$ \\
\hline
\end{tabular}


In order to better compare the sector sales to sales information from Quebec, the chemical group breakdown was conducted on the agricultural pesticide sales (Table 5). The chemical group breakdown was changed significantly to align with the Quebec system (Dion 2007), and as a result, there are no comparisons for most chemical groups between 2003 and 2008.

The Phosphonic/Phosphinic Acids group dominated the agricultural sales at over $54 \%$. The Phenoxy Acids group followed this at just over 16\%. The surfactants (Fatty Acids, Surfactants and Hydrocarbons) comprised the next two groups, making up a total of $13 \%$ of total agricultural sales. The remaining groups comprised less than $3 \%$ or less individually, or slightly over $16 \%$ combined.

Table 5. Summary of Agricultural Pesticide Sales by Chemical Group

\begin{tabular}{|l|r|r|}
\hline & \multicolumn{2}{|c|}{$\mathbf{2 0 0 8}$} \\
\hline \hline \multicolumn{1}{|c|}{ Chemical Group } & \multicolumn{1}{|c|}{ Kg ai } & \% \\
\hline Phosphonic Acids, Phosphinic Acids & 6522273.7 & 54.4 \\
\hline Phenoxy Acids & 1938624.1 & 16.2 \\
\hline Fatty Acids \& Surfactants & 918522.1 & 7.7 \\
\hline Hydrocarbons & 656588.2 & 5.5 \\
\hline Benzonitriles & 362733.9 & 3.0 \\
\hline Cyclohexanedione oximes & 191948.1 & 1.6 \\
\hline Dinitrobenzenes & 118607.6 & 1.0 \\
\hline Thiocarbamates & 112096.2 & 0.9 \\
\hline Aryloxyphenoxyl Acids & 110792.2 & 0.9 \\
\hline Imidazolinones & 108067.7 & 0.9 \\
\hline Triazoles & 100015.6 & 0.8 \\
\hline Biscarbamates & 99910.8 & 0.8 \\
\hline Thiophosphates & 85072.1 & 0.7 \\
\hline Acylureas & 81590.3 & 0.7 \\
\hline Benzoic Acid \& Derivatives & 78065.3 & 0.7 \\
\hline Pyridines & 72222.2 & 0.6 \\
\hline Halogenated Organic Acids & 68986.3 & 0.6 \\
\hline Dithiophosphates & 50761.6 & 0.4 \\
\hline Inorganics, Other & 46177.8 & 0.4 \\
\hline Azoles, Oxazoles, Thiazoles & 41210.3 & 0.3 \\
\hline Ammoniums, Quaternary & 40464.0 & 0.3 \\
\hline Sulfonylureas & 27585.8 & 0.2 \\
\hline Anilides & 26870.7 & 0.2 \\
\hline Phthalic Acids & 26841.1 & 0.2 \\
\hline Methoxyacrylates & 20243.1 & 0.2 \\
\hline Urea Derivatives & 15969.3 & 0.1 \\
\hline Morpholines \& Oxathiines & 14366.9 & 0.1 \\
\hline Chlorotriazines & 10785.3 & 0.07 \\
\hline Carbamates & 8034.9 & 0.06 \\
\hline Miscellaneous (Non-Classified) & 6834.3 & 0.06 \\
\hline Guanidines & 6770.1 & 5916.6 \\
\hline Triazines, Tetrazines & & 0.05 \\
\hline
\end{tabular}




\begin{tabular}{|l|r|r|}
\hline Pyrethroids, Pyrethrins & 3479.7 & 0.03 \\
\hline Inorganic Coppers & 3407.7 & 0.03 \\
\hline Diazines & 940.1 & 0.008 \\
\hline Phosphates & 809.9 & 0.007 \\
\hline Phosphoramidothioates & 415.7 & 0.003 \\
\hline Benzamides & 397.5 & 0.003 \\
\hline Organochlorines & 256.5 & 0.002 \\
\hline Microbials & 124.1 & 0.001 \\
\hline Amides & 121.3 & 0.001 \\
\hline Nitrobenzenes & 76.6 & 0 \\
\hline Oximes-Carbamates & 24.3 & 0 \\
\hline Inorganic Zincs & 23.6 & 0 \\
\hline Aldehydes & 8.9 & 0 \\
\hline Chromenones & 6.8 & 0 \\
\hline Organic Acids & 5.0 & 0 \\
\hline Indanediones & 1.8 & 0 \\
\hline \hline Total & $\mathbf{1 1 9 5 5 0 4 7 . 9}$ & $\mathbf{1 0 0}$ \\
\hline
\end{tabular}

\subsubsection{Domestic Sector}

In the domestic sector (Figure 2), herbicides again dominated at just over 68\%, however insecticide sales made up a significant proportion of pesticide sales at over $27 \%$. Fungicide sales were proportionately similar to agricultural fungicide sales, at close to $3 \%$.

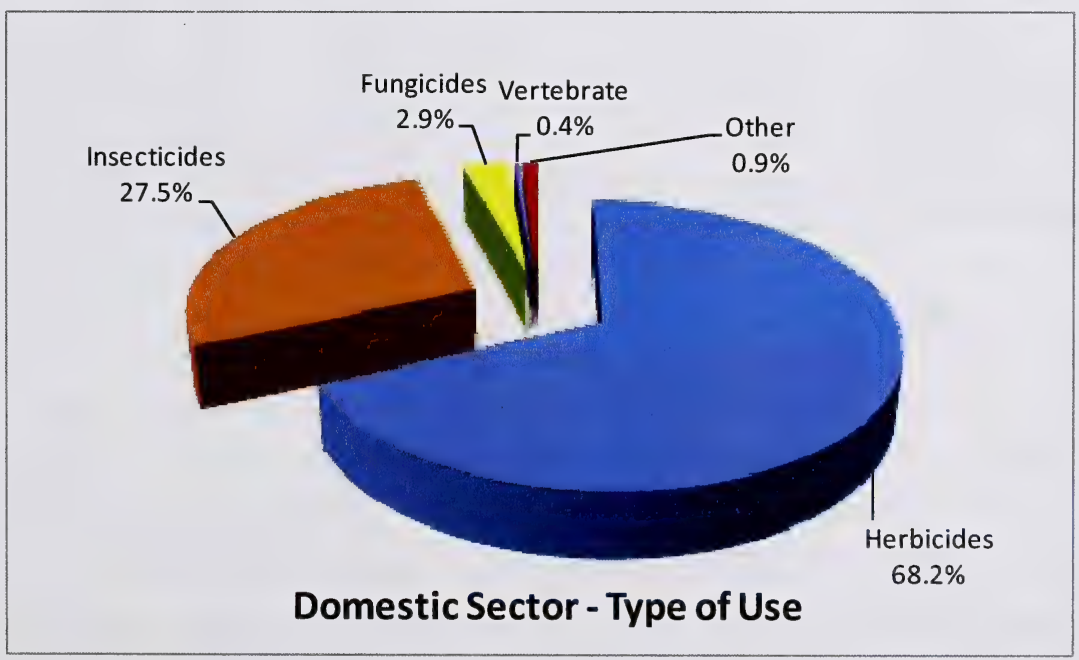

Figure 2. Domestic Sector - Type of Use

As with the agricultural products, the domestic product sales were also broken down by chemical group (Table 6). In the Domestic sector, the Phenoxy Acids dominated at over $41 \%$ of total 
pesticide sales, followed by Inorganics and Phosphonic/Phosphinic Acids. These three groups combined made up over $73 \%$ of all domestic sales.

Table 6. Summary of Domestic Pesticide Sales by Chemical Group - 2008

\begin{tabular}{|c|c|c|}
\hline Chemical Group & Kg ai & $\%$ \\
\hline Phenoxy Acids & 37194.2 & 41.5 \\
\hline Inorganics, Other & 16388.0 & 18.3 \\
\hline Phosphonic Acids, Phosphinic Acids & 12195.8 & 13.6 \\
\hline Carbamates & 5451.6 & 6.1 \\
\hline Dithiophosphates & 3138.0 & 3.5 \\
\hline Hydrocarbons & 2932.9 & 3.3 \\
\hline Fatty Acids \& Surfactants & 2241.5 & 2.5 \\
\hline Organic Acids & 1843.7 & 2.1 \\
\hline Oils, Mineral and Vegetable & 1729.5 & 1.9 \\
\hline Miscellaneous (Non-Classified) & 1604.6 & 1.8 \\
\hline Benzamides & 1201.7 & 1.3 \\
\hline Benzoic Acid \& Derivatives & 904.7 & 1.0 \\
\hline Inorganic Coppers & 593.3 & 0.7 \\
\hline Pyrethroids, Pyrethrins & 576.0 & 0.6 \\
\hline Organochlorines & 510.3 & 0.6 \\
\hline Biscarbamates & 223.7 & 0.2 \\
\hline Phthalic Acids & 211.6 & 0.2 \\
\hline Inorganic Zincs & 153.5 & 0.2 \\
\hline Chlorotriazines & 134.2 & 0.1 \\
\hline Phosphates & 112.6 & 0.1 \\
\hline Aldehydes & 104.5 & 0.1 \\
\hline Triazoles & 44.7 & 0.05 \\
\hline Chromenones & 34.9 & 0.04 \\
\hline Microbials & 3.8 & 0.0 \\
\hline Alcohols & 1.3 & 0.0 \\
\hline Amides & 1.2 & 0.0 \\
\hline Indanediones & 0.8 & 0.0 \\
\hline Diazines & 0.4 & 0.0 \\
\hline Pheromones & 0.2 & 0.0 \\
\hline Ammoniums, Quaternary & 0.15 & 0.0 \\
\hline Azoles, Oxazoles, Thiazoles & 0.03 & 0.0 \\
\hline Thiophosphates & 0.009 & 0.0 \\
\hline Total & 89533.6 & 100.0 \\
\hline
\end{tabular}


The top domestic products sold in 2008 are listed in Table 7. Turf herbicides dominated (2,4-D and mecoprop), while glyphosate sales were also high. Glyphosate (and glufosinate) sales have increased as other total vegetation control products (e.g., atrazine, bromacil, etc) have been removed from the domestic market. Ferrous sulfate (used for moss control) sales have increased significantly since 2003. Silicon dioxide (salt water fossils) sales remained high in 2008, as products containing this active ingredient are being more widely utilized for insect control in indoor situations. A new formulation of fresh water fossils was also sold in 2008. Carbaryl sales, primarily used for ant control, increased as it was being used as a replacement for some of the organophosphate products removed from the domestic market (e.g., diazinon, dimethoate).

Table 7. Top 15 Domestic Active Ingredients Sold in 2008, 2003 and 1998

\begin{tabular}{|l|r|r|r|}
\hline Domestic active ingredient & $\mathbf{2 0 0 8} \mathbf{~ K g}$ ai & $\mathbf{2 0 0 3} \mathbf{~ k g}$ ai & $\mathbf{1 9 9 8} \mathbf{~ k g}$ ai \\
\hline 2,4-D & 25107.2 & 14392.5 & 22505.1 \\
\hline Mecoprop & 12087.0 & 6273.8 & 9313.6 \\
\hline Glyphosate & 11167.6 & 10448.5 & 6099.4 \\
\hline Ferrous sulfate & 7846.4 & 1593.4 & 1818.7 \\
\hline Silicon dioxide salt water fossils & 6666.6 & 7509.2 & 2962.7 \\
\hline Carbaryl & 5433.4 & 3151.9 & 1292.2 \\
\hline Malathion & 3116.7 & 1667.8 & 2655.6 \\
\hline Naphthalene & 2318.2 & 118.5 & 1371.6 \\
\hline Acetic acid & 1815.5 & 1130.5 & 0.0 \\
\hline Mineral oil (Insecticidal or adjuvant) & 1701.4 & 838.9 & 2986.9 \\
\hline Soap & 1331.8 & 815.8 & 1211.1 \\
\hline Deet & 1201.7 & 3413.3 & 3972.2 \\
\hline Glufosinate ammonium & 1028.2 & 564.4 & 463.0 \\
\hline Sulphur (fungicide) & 943.2 & 722.8 & 957.5 \\
\hline Dicamba & 894.0 & 440.7 & 689.3 \\
\hline
\end{tabular}

\subsubsection{Commercial/Industrial Sector}

In the Commercial/Industrial Sector, herbicides again dominated at $90 \%$ of pesticide sales (Figure 3). Insecticides made up over 3\%. Fungicide sales were proportionately slightly higher in this sector at $5 \%$, a reflection of fungicide sales to the golf course industry. Table 8 provides a more detailed breakdown of the top 15 active ingredients that were classified as being sold and used in the commercial/industrial sectors, and reflects the dominance of products sold and used for industrial site and right-of-way maintenance. Methyl bromide sales were reported in 2008, and this was for a flour mill fumigation under a critical use exemption permit for this product. 


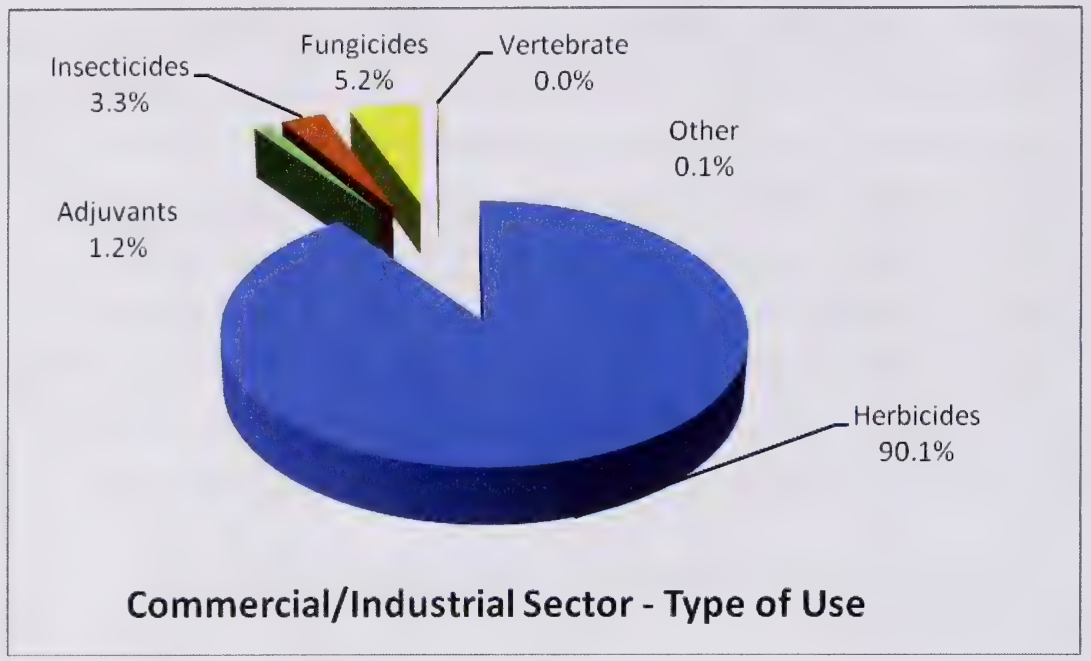

Figure 3. Commercial/Industrial Sector - Type of Use

Table 8. Top 15 Commercial/Industrial Active Ingredients Sold in 2008, 2003 and 1998

\begin{tabular}{|l|r|r|r|}
\hline $\begin{array}{l}\text { Commercial/Industrial } \\
\text { Active Ingredient }\end{array}$ & 2008 kg ai & 2003 kg ai & 1998 kg ai \\
\hline 2,4-D & 107510.5 & 63670.6 & 68412.7 \\
\hline Glyphosate & 99021.2 & 75379.1 & 49050.2 \\
\hline Diuron & 31707.3 & 28960.0 & 9627.5 \\
\hline Triclopyr & 23932.8 & 29625.6 & 29908.8 \\
\hline Mecoprop & 19933.7 & 12288.0 & 10991.2 \\
\hline Dicamba & 15931.9 & 12344.2 & 18849.5 \\
\hline Picloram & 14574.7 & 13302.3 & 14633.6 \\
\hline Acetic acid & 10095.0 & 425.0 & 0.0 \\
\hline Acrolein & 9051.0 & 16981.4 & 17520.5 \\
\hline Quintozene & 7528.8 & 6829.0 & 9808.8 \\
\hline Methyl bromide & 6106.3 & 0.0 & 0.0 \\
\hline Amitrole & 3929.3 & 2.3 & 0.0 \\
\hline Imazapyr & 3739.2 & 1675.8 & 200.6 \\
\hline Chlorothalonil & 3605.0 & 4363.5 & 6768.3 \\
\hline Aminopyralid & 3539.6 & 0.0 & 0.0 \\
\hline
\end{tabular}

The Commercial/Industrial sector sales were also broken down by chemical group (Table 9). In this sector, the Phenoxy Acids were the largest group by sales, with the Phosphonic/Phosphinic Acids following. These two groups of herbicides made up over $65 \%$ of total sales in this sector, reflecting the predominance of the industrial facility maintenance and commercial landscape industries in this sector. 
Table 9. Summary of Commercial/Industrial Pesticide Sales by Chemical Group - 2008

\begin{tabular}{|c|c|c|}
\hline Chemical Group & Kg ai & $\%$ \\
\hline Phenoxy Acids & 154836.4 & 39.9 \\
\hline Phosphonic Acids, Phosphinic Acids & 99098.0 & 25.5 \\
\hline Urea Derivatives & 31716.9 & 8.2 \\
\hline Halogenated Organic Acids & 19088.3 & 4.9 \\
\hline Benzoic Acid \& Derivatives & 15938.2 & 4.1 \\
\hline Organic Acids & 10199.7 & 2.6 \\
\hline Miscellaneous (Non-Classified) & 9139.3 & 2.4 \\
\hline Nitrobenzenes & 7550.4 & 1.9 \\
\hline Organohalogens & 6106.3 & 1.6 \\
\hline Triazoles & 4646.5 & 1.2 \\
\hline Acylureas & 4022.2 & 1.0 \\
\hline Fatty Acids \& Surfactants & 3917.1 & 1.0 \\
\hline Imidazolinones & 3739.2 & 1.0 \\
\hline Benzonitriles & 3709.4 & 1.0 \\
\hline Biscarbamates & 2679.0 & 0.7 \\
\hline Oils, Mineral and Vegetable & 2196.3 & 0.6 \\
\hline Alcohols & 1690.2 & 0.4 \\
\hline Carbamates & 1399.8 & 0.4 \\
\hline Morpholines \& Oxathiines & 1086.1 & 0.3 \\
\hline Inorganics, Other & 1031.9 & 0.3 \\
\hline Pyrethroids, Pyrethrins & 456.2 & 0.1 \\
\hline Aldehydes & 456.0 & 0.1 \\
\hline Dithiophosphates & 421.9 & 0.1 \\
\hline Dithiocarbamates & 392.0 & 0.1 \\
\hline Diazines & 350.6 & 0.1 \\
\hline Microbials & 292.5 & 0.1 \\
\hline Methoxyacrylates & 289.0 & 0.1 \\
\hline Ammoniums, Quaternary & 258.7 & 0.1 \\
\hline Sulfonylureas & 258.3 & 0.1 \\
\hline Phosphoramidothioates & 210.5 & 0.1 \\
\hline Thiophosphates & 195.4 & 0.1 \\
\hline Pheremones & 176.5 & 0.05 \\
\hline Phosphates & 155.1 & 0.04 \\
\hline Amides & 148.4 & 0.04 \\
\hline Inorganic Coppers & 140.5 & 0.04 \\
\hline Benzamides & 94.9 & 0.02 \\
\hline Guanidines & 79.3 & 0.02 \\
\hline Phthalic Acids & 72.0 & 0.02 \\
\hline Azoles, Oxazoles, Thiazoles & 70.1 & 0.02 \\
\hline Organochlorines & 63.5 & 0.02 \\
\hline Anilides & 47.5 & 0.01 \\
\hline Pyridines & 44.3 & 0.01 \\
\hline Chlorotriazines & 33.8 & 0.01 \\
\hline Indanediones & 22.1 & 0.01 \\
\hline Organometallics & 8.6 & 0.0 \\
\hline
\end{tabular}




\begin{tabular}{|l|r|r|}
\hline Triazines, Tetrazines & 2.7 & 0.0 \\
\hline Inorganic Zincs & 2.7 & 0.0 \\
\hline Oximes-Carbamates & 2.4 & 0.0 \\
\hline Chromenones & 0.5 & 0.0 \\
\hline Dinitrobenzenes & 0.00004 & 0.0 \\
\hline Total & $\mathbf{3 8 8 5 3 7 . 0}$ & $\mathbf{1 0 0 . 0}$ \\
\hline
\end{tabular}

\subsubsection{Other Sectors}

Pesticide sales in the Livestock sector consisted of primarily repellents or insecticides, used for direct application to livestock or as space controls or repellents in the buildings used for sheltering livestock. The top four products by sales (with sector sales percentages and specific uses) were butoxypropylene glycol (32\% - repellent), malathion ( $22 \%$ - insecticide), sulphur $(10 \%$ - insecticide used in combination with rotenone) and piperonyl butoxide ( $10 \%$ - synergist used with pyrethrins).

\subsection{Geographic Distributions}

\subsubsection{Drainage Basin}

\subsubsection{Agricultural Usage}

Sales of all agricultural products (excluding adjuvants) were broken down by drainage basin (Table 10 and Figure 4). The Oldman River basin had the highest proportion of agricultural pesticide sales, at almost $20 \%$, followed by the Red Deer River basin, the Battle River and the North Saskatchewan River basin. The Peace River basin also had over $11 \%$ of total agricultural pesticide sales, while the remaining basins were all below $10 \%$.

Table 10. Agricultural Pesticide Sales (excluding adjuvants) by River Basin

\begin{tabular}{|l|r|r|r|r|}
\hline & \multicolumn{2}{|c|}{$\mathbf{2 0 0 8}$} & \multicolumn{2}{c|}{$\mathbf{2 0 0 3}$} \\
\hline River Basin & \multicolumn{1}{|c|}{ Kg ai } & \multicolumn{1}{c|}{ Ko) } & \multicolumn{1}{c|}{ Kg } & (\%) \\
\hline Oldman River & 2068309.6 & 19.9 & 1615182.5 & 21.4 \\
\hline Red Deer River & 1770580.7 & 17.0 & 1334005.1 & 17.6 \\
\hline Battle River & 1544739.9 & 14.8 & 1108136.4 & 14.6 \\
\hline North Saskatchewan River & 1393229.6 & 13.4 & 1137851.8 & 15.0 \\
\hline Peace River & 1202936.2 & 11.6 & 731480.1 & 9.7 \\
\hline South Saskatchewan River & 872798.3 & 8.4 & 647561.2 & 8.6 \\
\hline Bow River & 825266.5 & 7.9 & 536221.4 & 7.1 \\
\hline Athabasca River & 360375.6 & 3.5 & 234328.2 & 3.1 \\
\hline Sounding Creek & 213163.7 & 2.0 & 113392.8 & 1.5 \\
\hline Milk River & 79640.0 & 0.8 & 34858.4 & 0.5 \\
\hline Beaver River & 77237.5 & 0.7 & 64767.2 & 0.9 \\
\hline Non-specific basin & 1368.5 & 0.0 & 4069.1 & 0.05 \\
\hline Total & $\mathbf{1 0 4 0 9 6 4 6 . 5}$ & $\mathbf{1 0 0}$ & $\mathbf{7 5 6 1 8 5 3 . 9}$ & $\mathbf{1 0 0}$ \\
\hline
\end{tabular}




\subsubsection{Domestic Pesticide Sales by River Basin}

Sales of domestic products were also broken down by river basin (Table 11). In this category, sales by river are influenced by the two major population centres in Alberta and their metropolitan areas: Calgary and Edmonton. The North Saskatchewan and Bow River basins had the largest sales by basin, followed by the Battle and Red Deer River basins. All basins (except for the Sounding Creek, Milk River and Hay River basins) increased in sales volumes from 2003, with the largest proportional sales volume increase observed in the Battle River. Some of the increase could be attributed to better spatial resolution in the sales data provided, as the sales volumes not assigned to a river basin dropped by over $11000 \mathrm{~kg}$ in 2008 even though overall sales went up.

Table 11. Total Domestic Pesticide Sales by River Basin

\begin{tabular}{|l|r|r|}
\hline River Basin & 2008 Kg ai & \multicolumn{1}{c|}{$\mathbf{2 0 0 3} \mathbf{~ K g}$ ai } \\
\hline \hline North Saskatchewan & 26095.2 & 10248.9 \\
\hline Bow River & 20276.6 & 10652.4 \\
\hline Battle River & 9785.4 & 2370.5 \\
\hline Red Deer River & 7208.1 & 3710.2 \\
\hline Oldman River & 5106.9 & 2638.9 \\
\hline Athabasca River & 4015.1 & 2777.8 \\
\hline Peace River & 3532.3 & 2244.5 \\
\hline South Saskatchewan River & 2816.8 & 1602.0 \\
\hline Beaver River & 912.1 & 368.9 \\
\hline Sounding Creek & 88.8 & 157.3 \\
\hline Milk River & 42.5 & 45.0 \\
\hline Hay River & 2.5 & 0.5 \\
\hline Non-specific basin & 9651.3 & 21894.9 \\
\hline Total & $\mathbf{8 9 5 3 3 . 6}$ & $\mathbf{5 8 7 1 1 . 7}$ \\
\hline
\end{tabular}

\subsubsection{Pesticide Sales by Natural Region}

Pesticide sales were also broken down by natural region to assess pesticide sales/usage in relation to the natural regions in Alberta, which represent areas of comparable soils, climate and vegetation (Table 12). This information is of interest in relation to cropping practices that are often comparable within these regions.

Pesticide sales were concentrated in three natural regions in Alberta (Table 12) (Boreal, Grassland and Parkland). The largest amount of pesticide sold, at over $32 \%$ of provincial sales, 
was in the Central Parkland sub-region. The Dry Mixedgrass sub-region was next at $18.3 \%$, followed by the Mixedgrass sub-region at $17.1 \%$, and the Dry Mixedwood sub-region at $13.3 \%$. Overall, the Grassland and Parkland natural regions comprised the bulk of sales within the province.

Mapping of the sales by natural region was also conducted, with Figure 5 displaying the geographical locations of the natural regions and sub-regions.

Table 12. Total Pesticide Sales by Natural Region

\begin{tabular}{|c|c|c|c|c|}
\hline Natural Region & Sub Region & $2008 \mathrm{~kg}$ ai & $\begin{array}{l}2008 \\
\%\end{array}$ & $2003 \mathrm{~kg}$ ai \\
\hline Alberta (non-specific region) & & 217799.0 & 1.7 & 213905.0 \\
\hline \multirow{3}{*}{ Boreal } & Central Mixedwood & 21549.7 & 0.2 & 31486.3 \\
\hline & Dry Mixedwood & 1664332.9 & 13.3 & 1126572.7 \\
\hline & Lower Boreal Highlands & 2.4 & 0.0 & 0.5 \\
\hline Boreal Total & & 1685885.0 & 13.5 & 1158059.5 \\
\hline \multirow[t]{2}{*}{ Foothills } & Lower Foothills & 5652.2 & 0.04 & 10557.4 \\
\hline & Upper Foothills & 15.0 & 0.0 & 29.1 \\
\hline Foothills Total & & 5667.1 & 0.04 & 10586.5 \\
\hline \multirow[t]{4}{*}{ Grassland } & Dry Mixedgrass & 2284841.7 & 18.3 & 1831323.8 \\
\hline & Foothills Fescue & 1061066.0 & 8.5 & 711924.8 \\
\hline & Mixedgrass & 2128080.6 & 17.1 & 1414122.2 \\
\hline & Northern Fescue & 584808.0 & 4.7 & 328584.0 \\
\hline Grassland Total & & 6058796.4 & 48.6 & 4285954.8 \\
\hline \multirow[t]{3}{*}{ Parkland } & Central Parkland & 3986293.9 & 32.0 & 3258822.0 \\
\hline & Foothills Parkland & 8898.9 & 0.1 & 2113.7 \\
\hline & Peace River Parkland & 510644.9 & 4.1 & 334291.9 \\
\hline Parkland Total & & 4505837.6 & 36.1 & 3595227.6 \\
\hline Rocky Mountain & Montane & 2110.7 & 0.02 & 754.3 \\
\hline Total & & 12476095.8 & 100 & 9264487.7 \\
\hline
\end{tabular}

\subsubsection{Total Pesticide Sales by Land Use Framework Region}

The Government of Alberta initiated a new program in 2006 to develop a provincial land use planning blueprint to better manage public and private lands and natural resources to achieve Alberta's long term goals (Land Use Secretariat 2008). The Land Use Framework is intended to balance economic, social and environmental interests competing to utilize the same land base. The provincial framework is broken down into seven regional planning areas, which are aligned by river basins at a broad scale, and by municipal boundaries at the fine scale. 
Because the Land Use Framework (LUF) boundaries roughly align with river basins, there is some alignment in Table 13 with Table 10 (agricultural sales by basin) and Table 11 (domestic sales by basin). However, the northern basins (Peace and Athabasca) are broken into two LUF regions (Upper and Lower), while the Bow, Oldman and South Saskatchewan basins are combined into one LUF region (South Saskatchewan). The Battle River is incorporated into the North Saskatchewan region, while the Beaver River is encompassed into the Lower Athabasca region (Figure 6).

The consolidation of three river basins into the South Saskatchewan region results in this region having the largest volume of sales, at over $40 \%$ of the provincial total. The bisection of the two largest river basins in Alberta (Athabasca and Peace) into Upper and Lower regions limits the relative sales for these four regional planning areas.

Table 13. Total Pesticide Sales by Land Use Framework Region

\begin{tabular}{|l|r|r|}
\hline Land Use Framework Region & \multicolumn{1}{|l|}{ Kg ai } & \multicolumn{1}{l|}{$\%$} \\
\hline Alberta & 217799.0 & 1.8 \\
\hline Lower Athabasca & 70997.7 & 0.6 \\
\hline Upper Athabasca & 434667.3 & 3.5 \\
\hline Lower Peace & 355240.3 & 2.9 \\
\hline Upper Peace & 1049653.6 & 8.4 \\
\hline North Saskatchewan & 3139318.3 & 25.2 \\
\hline Red Deer & 2136500.6 & 17.1 \\
\hline South Saskatchewan & 5071919.0 & 40.6 \\
\hline \hline Total & $\mathbf{1 2 4 7 6 0 9 5 . 8}$ & $\mathbf{1 0 0}$ \\
\hline
\end{tabular}

\subsubsection{Pesticide Sales by Municipality}

Agricultural pesticide sales were broken out by rural municipality to provide a detailed geoadministrative overview of sales, using Alberta rural municipal boundaries. The largest volume of sales (agricultural products excluding adjuvants) occurred in the County of Lethbridge and the Wheatland County ( $>500,000 \mathrm{~kg}$ ai), which are major supply and distribution centres for southern Alberta. Municipalities with greater than $300000 \mathrm{~kg}$ ai of sales were the MD of Taber, Cypress, Vulcan, Vermilion River, Forty Mile, Camrose, Rocky View and Kneehill Counties. These are large municipalities with the highest proportion of total crop area in Alberta (AARD 2009). Data on primary crops grown in 2006 in the five municipalities with the highest use intensity $(>1.5$ $\mathrm{kg} / \mathrm{ha}$ ) was derived from the 2006 Census of Agriculture (AARD 2009)(Table 14). Acreages for major crop groups varied among municipality, however cereals (primarily wheat) dominated in 
each municipality. Oilseeds (primarily canola) did not have relatively high acreage in comparison to wheat except in Camrose County. Potatoes and sugar beets accounted for most of the Other Field Crops grown in Taber and Lethbridge, while field peas and dry beans were extensively grown in the other municipalities. Vegetable production was predominately in the irrigated municipalities of Taber and Lethbridge, while Hay and Forage acreage was largest in Cypress County. Statistics Canada included more data on chemfallow acreage in 2006, so this data was included in the summary table, as chemfallow represents a significant usage of herbicide products.

The range of crop types in various municipalities influences the type of pesticides used, as well as the use intensity (rate and frequency of application). Potatoes and sugar beets use very different products than cereals and oilseeds, and pesticide use is often more intensive on these types of crops for disease suppression, weed control and insect control. This is reflected in the use intensities for Taber and Lethbridge, which are again the top two municipalities for use intensity. These municipalities may also serve as regional supply centres, so the use intensities for these two municipalities may be a slight overestimation.

Table 14. Breakdown by Municipality of 2006 Crop (ha), Agricultural Pesticide Sales (2008 $\mathrm{kg}$ ai), and Use Intensity (kg ai/ha)

\begin{tabular}{|l|r|r|r|r|r|r|}
\hline Crop Group & \multicolumn{1}{|c|}{ Alberta } & \multicolumn{1}{c|}{ Lethbridge } & \multicolumn{1}{l|}{ Taber } & \multicolumn{1}{c|}{ Cypress } & Wheatland & Camrose \\
\hline Cereals (acres) & 4788061 & 130824 & 100999 & 100999 & 204355 & 113919 \\
\hline Mixed Grains (acres) & 150950 & 1536 & 641 & 2261 & 811 & 3802 \\
\hline $\begin{array}{l}\text { Oilseeds (Canola, flax, } \\
\text { soy - acres) }\end{array}$ & 1671984 & 17345 & 18507 & 11392 & 53999 & 72509 \\
\hline $\begin{array}{l}\text { Other Field crops } \\
\text { (acres) }\end{array}$ & 520330 & 21991 & 50982 & 12268 & 8159 & 10808 \\
\hline Vegetables (acres) & 5339 & 448 & 2836 & 0 & 17 & 0 \\
\hline Hay \& Forage (acres) & 2426493 & 31016 & 18896 & 48098 & 33249 & 30852 \\
\hline $\begin{array}{l}\text { Summerfallow(chem.- } \\
\text { fallow) (acres) }\end{array}$ & 658862 & 15575 & 17222 & 42048 & 24543 & 2242 \\
\hline $\begin{array}{l}\text { Total Crop \& } \\
\text { Chemfallow (ha) }\end{array}$ & 10222020 & 218736 & 210082 & 217065 & 325132 & 234131 \\
\hline $\begin{array}{l}\text { Agric Sales (excl Adj) } \\
\text { (kg) }\end{array}$ & 10409647 & 837185 & 487640 & 446481 & 516887 & 362337 \\
\hline Use Intensity (kg/ha) & 1.02 & 3.83 & 2.32 & 2.06 & 1.59 & 1.55 \\
\hline
\end{tabular}

Total sales (all sectors and all products) for all of the municipalities in Alberta are summarized in Table 15. Sales by municipality data are biased slightly by the location and distribution of vendors. Some municipalities have extensive agricultural operations with a limited number of outlets, while other municipalities serve as regional supply outlets, and their sales may be slightly 
over represented in the breakdown (e.g., Lethbridge). Sales data not allocated to a specific municipality was included in the "Alberta" total.

As in previous years, the large and predominantly agricultural municipalities had the highest sales, with Lethbridge, Wheatland, Taber, Cypress, and Vulcan Counties having the highest sales. At the other end of the spectrum, pesticides sold in the National Parks were primarily domestic lawn and garden products. A graphical depiction of pesticide sales by municipality is given in Figure 7.

Table 15. Total Pesticide Sales by Municipality (2008)

\begin{tabular}{|c|c|c|c|c|c|}
\hline Municipality & Kg ai & Municipality & Kg ai & Municipality & Kg ai \\
\hline Lethbridge & 1000177.4 & Ponoka & 173175.1 & Bonnyville & 67722.9 \\
\hline Wheatland & 576455.2 & Westlock & 170261.1 & Athabasca & 64142.0 \\
\hline Taber & 573195.3 & Spirit River & 163199.5 & Pincher Creek & 59062.5 \\
\hline Cypress & 525765.1 & Paintearth & 142829.4 & Big Lakes & 54976.3 \\
\hline Vulcan & 506652.4 & Stettler & 142129.1 & City of Calgary & 43133.5 \\
\hline Vermilion River & 475171.6 & Leduc & 139019.5 & Special Area 2 & 35122.5 \\
\hline Forty Mile & 474253.5 & Lamont & 138689.6 & City of Edmonton & 26741.1 \\
\hline Camrose & 414750.3 & Northern Sunrise & 138409.0 & Lac Ste. Anne & 25888.9 \\
\hline Kneehill & 384403.1 & Lacombe & 137560.6 & Thorhild & 21432.3 \\
\hline Rocky View & 369716.9 & Cardston & 136783.3 & Clear Hills & 19775.2 \\
\hline Flagstaff & 335358.9 & Mountain View & 133737.4 & Greenview & 11257.1 \\
\hline Grande Prairie & 303074.9 & Strathcona & 132515.6 & Brazeau & 9600.9 \\
\hline Minburn & 258766.5 & Sturgeon & 132461.2 & Lesser Slave River & 7266.8 \\
\hline Red Deer & 255499.4 & Mackenzie & 116367.3 & Yellowhead & 5493.9 \\
\hline Drumheller & 249104.6 & Wetaskiwin & 111578.7 & Clearwater & 3816.6 \\
\hline Newell & 226747.2 & Barrhead & 104770.9 & Saddle Hills & 1972.6 \\
\hline Wainwright & 219899.3 & Northern Lights & 100319.3 & Wood Buffalo & 1857.3 \\
\hline Alberta & 217799.0 & Special Area 4 & 98725.0 & Woodlands & 1853.8 \\
\hline Special Area 3 & 214551.0 & Two Hills & 92553.7 & Ranchland & 1505.1 \\
\hline Provost & 209716.4 & Starland & 90242.9 & Lac La Biche & 1417.4 \\
\hline Smoky River & 205250.9 & Peace & 88005.5 & Opportunity & 144.6 \\
\hline Foothills & 200168.5 & Parkland & 80845.7 & Bighorn & 68.4 \\
\hline Warner & 196982.6 & Acadia & 79420.5 & Jasper Nat. Park & 13.6 \\
\hline Beaver & 186403.8 & St. Paul & 75922.0 & Banff Nat. Park & 13.1 \\
\hline Fairview & 184409.6 & Smoky Lake & 74074.6 & & \\
\hline \multirow[t]{2}{*}{ Willow Creek } & 181238.9 & Birch Hills & 72708.3 & & \\
\hline & & & & Total & 12476095.8 \\
\hline
\end{tabular}




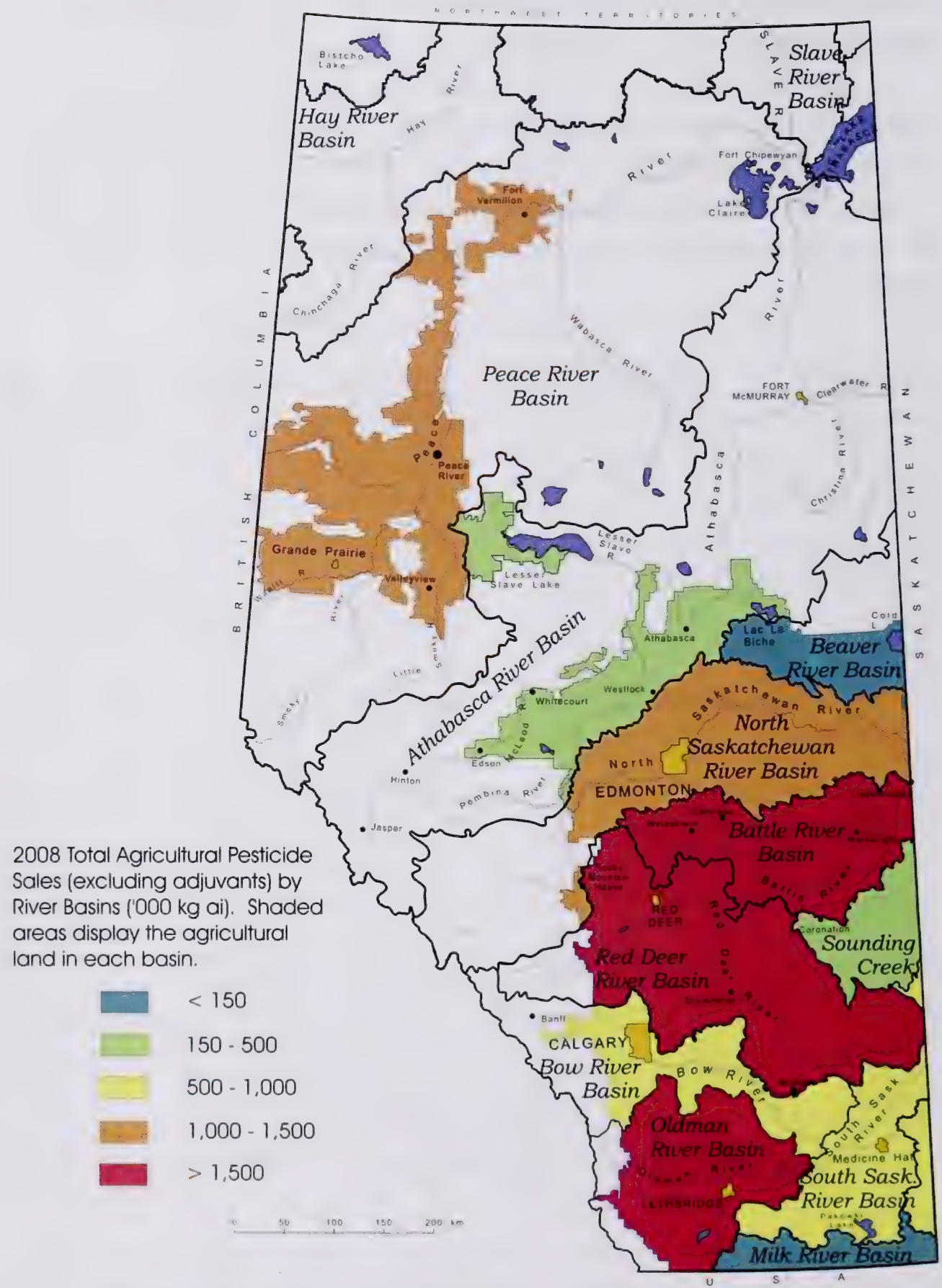

Figure 4. Total Agricultural Pesticide Sales (excluding adjuvants) By River Basin ('000 kg ai) - 2008 


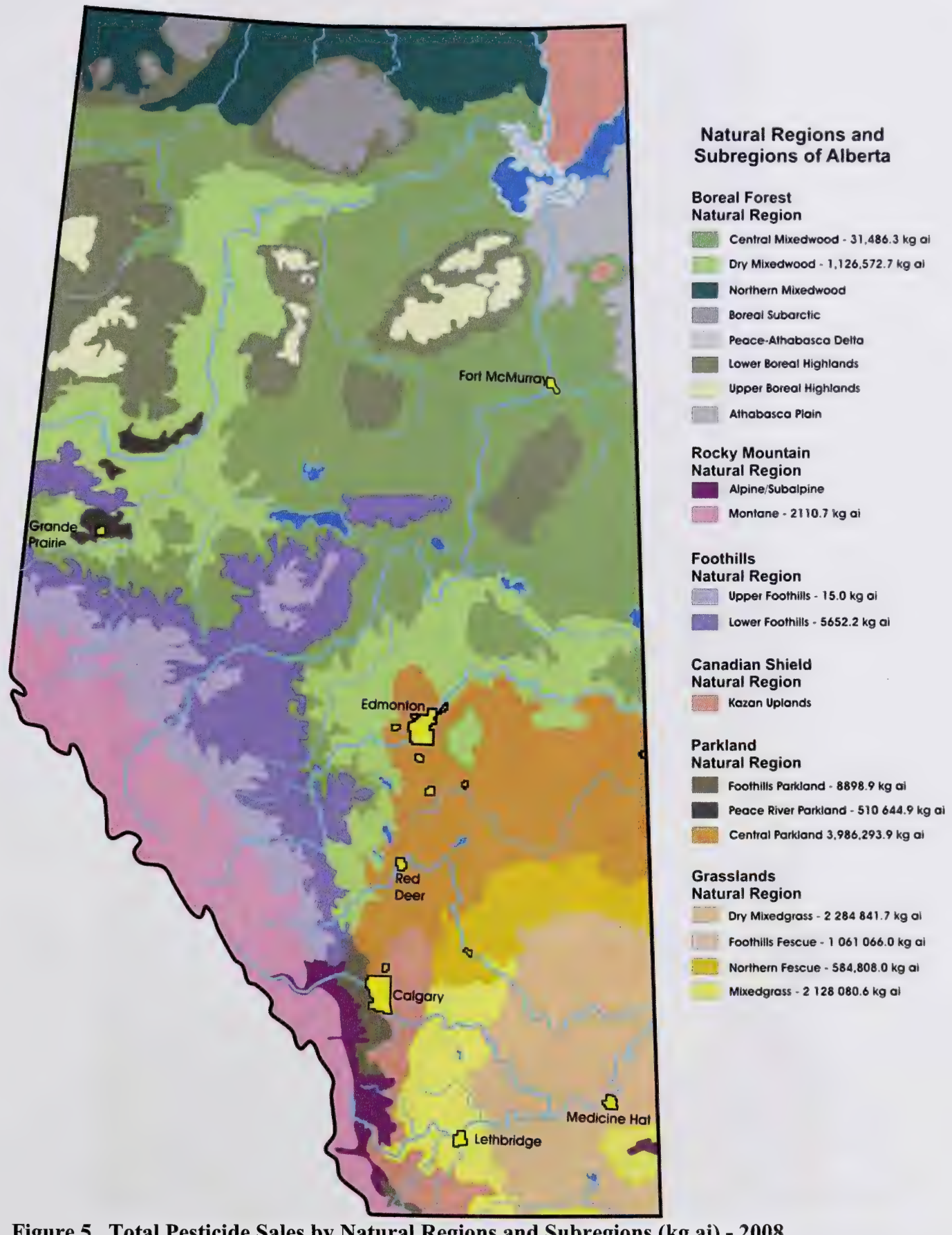

Figure 5. Total Pesticide Sales by Natural Regions and Subregions (kg ai) - 2008 


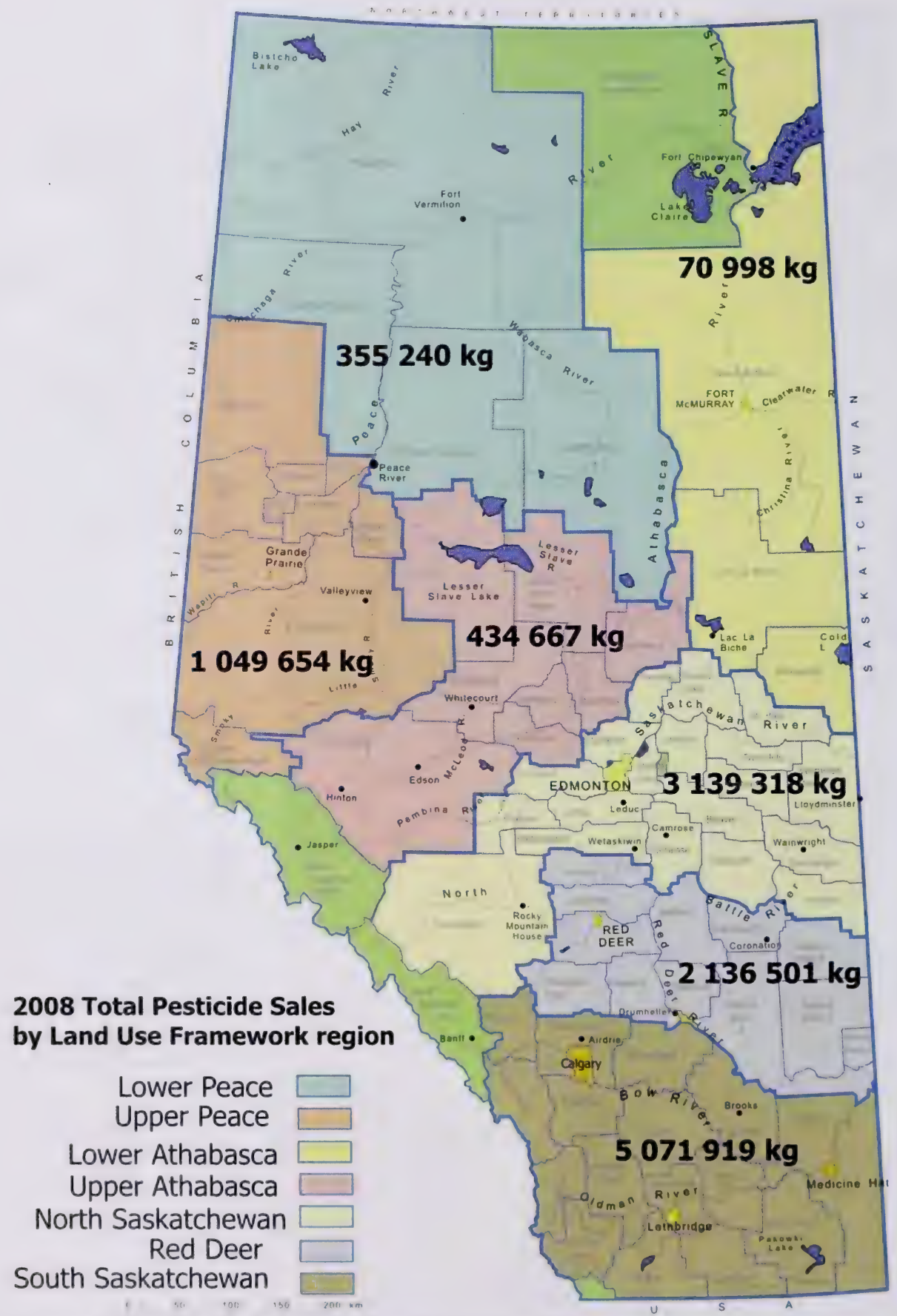

Figure 6. Total Pesticide Sales by Land Use Framework Region (kg ai) - 2008 


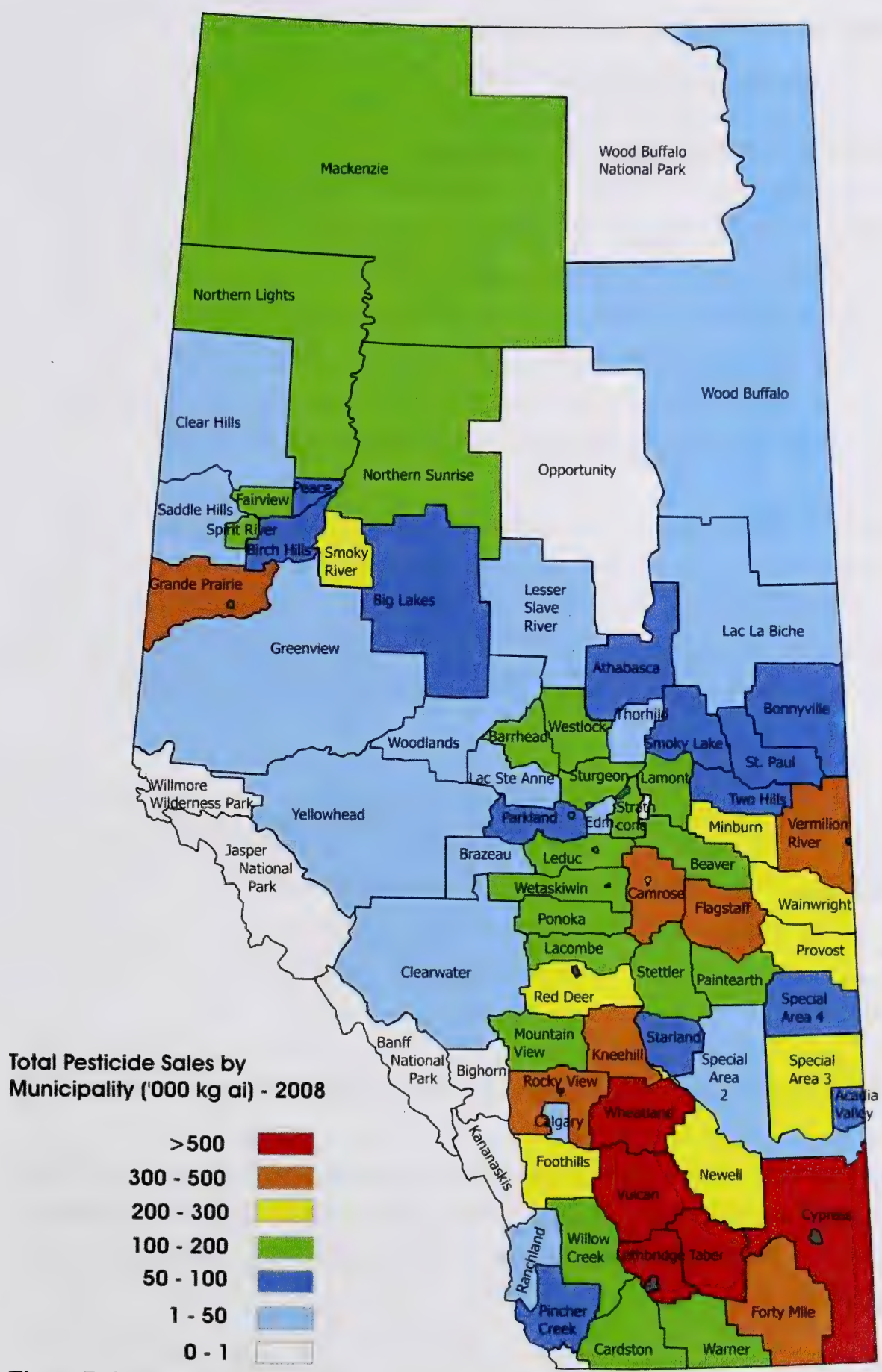

Figure 7. Total Pesticide Sales by Municipality ('000 kg ai) - 2008 


\subsection{DISCUSSION}

\subsection{Use Intensity-Alberta}

The first pesticide sales survey was conducted in Alberta for the 1988 to 1993 period for agricultural products only. It was followed by a comprehensive multi-sector survey in 1998 and again in 2003. The 1988 to 1993 sales data were based upon data obtained from the major line companies operating in Alberta at the time (e.g., grain handling companies). It did not include the sales data from independent dealers, which was estimated to make up approximately half of the market at the time. In order to make the 1988 and 1993 data consistent with more recent reporting, the sales totals obtained for those two years were doubled. The 1998, 2003 and 2008 surveys include data from the line companies and independent dealers, and are more comprehensive.

Total agricultural sales for those years were determined, and correlated to cropland information obtained from the Census of Agriculture, also carried out every 5 years (Pekalski 1995, AAFRD 2002; AARD 2009) (Table 16). The timing of the Census of Agriculture (years ending in 1 and 6) and the pesticide sales survey (years ending in 3 and 8 ) do not match, but the closest time periods are used for comparing and calculating overall agricultural pesticide use intensity for Alberta.

Table 16. Pesticide use comparisons 1988-2008 (excluding adjuvants)

\begin{tabular}{|l|l|l|l|l|l|}
\hline & $\mathbf{1 9 8 8}$ & $\mathbf{1 9 9 3}$ & $\mathbf{1 9 9 8}$ & $\mathbf{2 0 0 3}$ & $\mathbf{2 0 0 8}$ \\
\hline $\begin{array}{l}\text { Ag Pesticide Sales } \\
\text { (kg ai) }\end{array}$ & $6956950^{*}$ & $7491440^{*}$ & 7588662 & 7561854 & 10409646.5 \\
\hline $\begin{array}{l}\text { Cropland area } \\
\text { (ha)(census survey } \\
\text { year in brackets) }\end{array}$ & $\begin{array}{l}9162850 \\
(1986)\end{array}$ & $\begin{array}{l}9292374 \\
(1991)\end{array}$ & $\begin{array}{l}9,546,886 \\
(1996)\end{array}$ & $\begin{array}{l}9728527 \\
(2001)\end{array}$ & $\begin{array}{l}10222234 \\
(2006)\end{array}$ \\
\hline $\begin{array}{l}\text { Pesticide use } \\
\text { intensity (kg/ha) }\end{array}$ & 0.76 & 0.81 & 0.79 & 0.78 & 1.02 \\
\hline
\end{tabular}

*Reported sales in 1988 and 1993 were adjusted to provide an estimated total that could be compared to other years.

Overall agricultural pesticide use intensity was relatively consistent in Alberta between 1988 and 2003, fluctuating around $0.8 \mathrm{~kg} / \mathrm{ha}$. By 2008 however, overall pesticide use intensity increased to over $1 \mathrm{~kg} / \mathrm{ha}$, an increase of over $28 \%$ from 2003 , mainly a result of increased sales of glyphosate products (Table 4).

Cropland acreage used for the use intensity calculation also increased in 2008, mainly as result of including 660,000 ha of chemfallow in the total. The Statistics Canada agricultural census was 
changed between 2001 and 2006 to distinguish summerfallow practices between tillage and chemfallow, or a combination of both. The chemfallow and combined tillage/chemfallow acreages were summed to arrive at the additional acreage used in 2008. This acreage was included to reflect the increased use of glyphosate as a tool for controlling weeds on fallow land.

More detailed breakdown of pesticide sales by municipality (Figure 7) and calculated use intensity (Table 14) shows that high sales areas correspond to high use areas because of cropping practices in the area. For example, higher regional pesticide use intensity occurs in municipalities where irrigation farming is important, and where crop production and crop inputs for crops such as potatoes, sugar beets, and corn are higher than most dryland agricultural areas of the province. These municipalities are also characterized by proportionally large areas of productive farmland.

\subsection{Pesticide Use - Other Regions}

The most recent comprehensive report on pesticide sales in Canada was compiled by Environment Canada in 2005, based on 2001-2003 sales for most provinces (Brimble et al. 2005). That information was summarized in the 2003 Alberta sales report (Byrtus 2007).

\section{Quebec}

More recent information on 2007 pesticide sales in Quebec was recently released (Gorse and Dion 2010). Quebec pesticide sales in that year amounted to 3.9 million $\mathrm{kg}$ of active ingredient, and the sales have been fairly consistent since reporting started in 1992 (fluctuating in the range between 3.5 and 4.1 million $\mathrm{kg}$ ). Alberta's total pesticide sales in 2008 was 12.5 million $\mathrm{kg}$ of active ingredient, approximately three times that of Quebec's.

The distribution in type of use is markedly different between the two provinces (Table 17). Herbicide sales in Quebec made up only $51.1 \%$ of total sales, while Alberta's herbicide sales made up over $82 \%$. In Alberta, sales of adjuvants associated with the high proportion of herbicide sales were also proportionately high compared to Quebec. On the other hand, sales of fungicides and insecticides were both proportionately and numerically higher in Quebec than Alberta, reflecting different pest pressures in that region of the country. 
Table 17. Total Pesticide Sales by Type of Use for Alberta and Quebec

\begin{tabular}{|l|r|r|r|c|}
\hline & \multicolumn{2}{|c|}{ Alberta } & \multicolumn{2}{c|}{ Quebec } \\
\hline \hline Type of Use & $\mathbf{2 0 0 8} \mathbf{~ K g} \mathbf{~ a i}$ & $\mathbf{2 0 0 8} \mathbf{( \% )}$ & $\mathbf{2 0 0 7} \mathbf{~ k g}$ ai & $\mathbf{2 0 0 7} \%$ \\
\hline \hline Herbicides & 10253854 & 82.2 & 1993480 & 51.1 \\
\hline Fungicides & 388560 & 3.1 & 860417 & 22.1 \\
\hline Insecticides, Acaracides, Repellents & 236169 & 1.9 & 629946 & 16.2 \\
\hline Adjuvants and Surfactants & 1580104 & 12.7 & 128430 & 3.3 \\
\hline $\begin{array}{l}\text { Vertebrate Control Products and } \\
\text { Vertebrate Repellents }\end{array}$ & 12458 & 0.1 & 8871 & 0.2 \\
\hline Biocides & 275 & 0.00 & 204321 & 5.2 \\
\hline Soil Sterilants & 392 & 0.00 & 59755 & 1.5 \\
\hline Plant Growth Regulators & 3449 & 0.03 & 14569 & 0.4 \\
\hline Other & 834 & 0.01 & 155 & 0.0 \\
\hline \hline Total & $\mathbf{1 2 4 7 6 \mathbf { 0 9 6 }}$ & $\mathbf{1 0 0}$ & $\mathbf{3 8 9 9} \mathbf{9 4 4}$ & $\mathbf{1 0 0}$ \\
\hline
\end{tabular}

Quebec uses chemical groups to report on pesticide sales instead of individual active ingredients. Their top five groups are the Phosphonic/Phosphinic acids (26.3\%), Biscarbamates (14.3\%), Chlorotriazines (5.9\%), Phenoxy acids (5.5\%), and Dithiocarbamates (4.4\%). In Alberta, the top five chemical groups in sales are the Phosphonic/Phosphinic Acids (53.2\%), Phenoxy acids (17.1\%) Fatty Acids and Surfactants (7.4\%) Hydrocarbons (5.3\%) and Benzonitriles (2.9\%) (Appendix 2). This comparison illustrates that the makeup of products sold in Quebec and Alberta is dominated by the Phosphonic/Phosphinic acids (primarily glyphosate). Phenoxy acids (mainly 2,4-D \& MCPA) are also heavily used in both provinces. However, other than these two groups, the remaining high volume chemical groups were considerably different. Alberta's other major groups are dominated by adjuvants and surfactants, while Quebec's are dominated by fungicides (Biscarbamates) and the Chlorotriazines (e.g., atrazine), reflecting the different crops and pest pressures.

\section{U.S.A.}

Data from the U.S. for 2007 on total pesticide active ingredient usage (Grube et. al 2011) showed that herbicides made up only $47 \%$ of the U.S. pesticide market, with insecticides at $8 \%$, fungicides at $6 \%$, and Other products making up the remaining 39\%. This report also looked at the world pesticide market breakdown for 2007, which showed herbicides making up only $40 \%$, insecticides at $17 \%$, fungicides at $10 \%$, and Other products making up the remaining $33 \%$. From this information, it is apparent that Alberta's predominately herbicide based usage is a reflection of the relatively low insect and disease pressures that Alberta experiences compared to other regions of the world. 
The U.S report also provided a breakdown of pesticide use by sector. In 2007, Agriculture made up $80 \%$ of total pesticide use, Commercial and Industrial made up $12 \%$, and Home and Garden made up $8 \%$ of total use. Alberta's usage (Table 3 ) is weighted more towards the Agricultural sector (96.7\%), with limited usage in the Commercial/Industrial sector, and a very small proportion $(<1 \%)$ in the Domestic (Home and Garden) sector. The American data reflects a broader usage in their Commercial/Industrial sector, and their relatively higher Home and Garden usage is reflective of the large population base and a broader range of pest organisms. To put the American data in context, the total pesticide active ingredient used there in 2007 was a reported 857 million pounds ( 389 million $\mathrm{kg}$ ) of active ingredient, compared to just over 12 million $\mathrm{kg}$ ai for Alberta.

\subsection{Cropping Practices}

Seeding of herbicide tolerant canola in Alberta has influenced pesticide use and pesticide use changes over the past 15 years. Prior to herbicide tolerant canola coming onto the market, a wide spectrum of herbicides was required to control various broadleaf and grassy weeds in canola. Herbicide tolerant canola allowed full spectrum weed control with a single product (primarily glyphosate, although glufosinate and the imidazolinones such as imazethapyr, imazamox, and imazapyr have found niches). The Canola Council of Canada has compiled data from 1995 to 2010 to compare the Canadian cropping information on canola varieties from a number of sources (Canola Council 2010). It is assumed to be representative of Alberta cropping trends. The start date of 1995 reflects the period before herbicide tolerant varieties came onto the market, and the subsequent shifts towards Roundup Ready (glyphosate tolerant - transgenic), Liberty (glufosinate tolerant - transgenic) and Clearfield (imidazolinone tolerant - not transgenic) up to and including 2010 .

In 1995 conventional canola accounted for $100 \%$ of total seeded canola acres (Figure 8) in Canada. By 1998 it accounted for only $49 \%$, whereas by 2003 it accounted for only $12 \%$ of seeded acres. The Clearfield varieties started coming onto the market in 1996, peaking in 2000 at $25 \%$ and dropping to $13 \%$ by 2008 . Glyphosate and glufosinate tolerant varieties also came onto the market in 1996, and both types have increased in use over the years. By 2008, conventional varieties of canola had virtually dropped out of the marketplace $(1 \%)$, while glyphosate tolerant varieties made up $45 \%$ of the acreage seed, and glufosinate tolerant varieties made up $41 \%$. Total canola acreage harvested in Alberta fluctuated from year to year between 1996 and 2008, from 
1.7 million acres to almost 5.2 million acres (Table 18)(Alberta Canola Producers Commission 2003 and 2009).

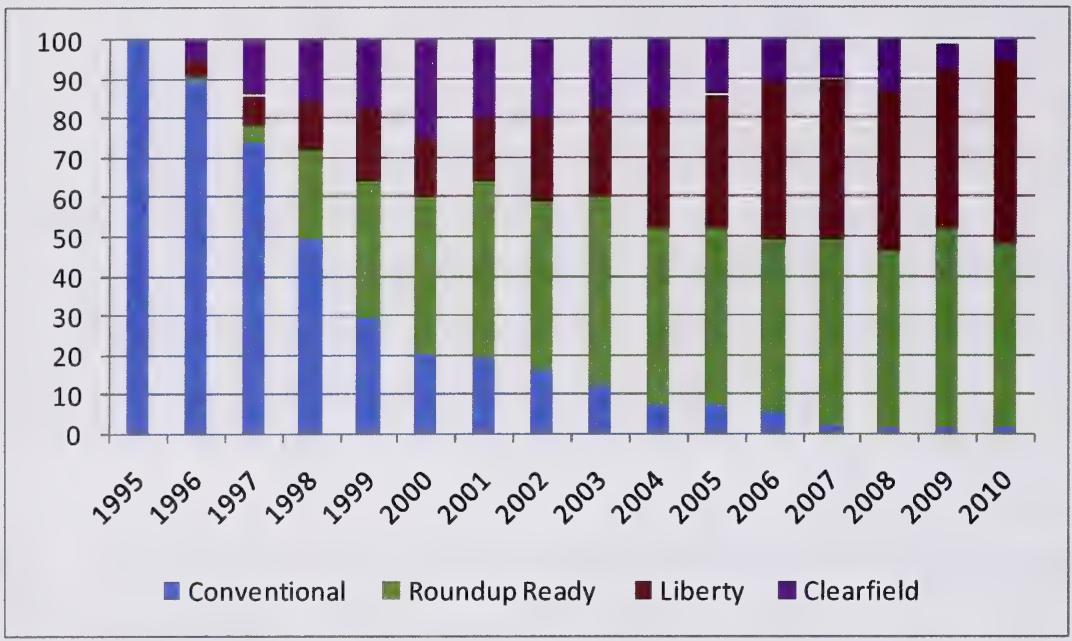

Figure 8. Canadian Canola Varieties - Percentage of Seeded Acres (1995-2010)

Table 18. Canola total acres harvested ('000's)

\begin{tabular}{|l|l|}
\hline & $\begin{array}{l}\text { Acres harvested } \\
\text { ('000 acres) }\end{array}$ \\
\hline 1996 & 3000 \\
\hline 1997 & 3950 \\
\hline 1998 & 4300 \\
\hline 1999 & 4520 \\
\hline 2000 & 3800 \\
\hline 2001 & 2850 \\
\hline 2002 & 1700 \\
\hline 2003 & 3300 \\
\hline 2004 & 3800 \\
\hline 2005 & 4250 \\
\hline 2006 & 4480 \\
\hline 2007 & 4460 \\
\hline 2008 & 5170 \\
\hline
\end{tabular}

Agricultural pesticide sales data reflect the changes in products used on herbicide tolerant canola (Figure 9). Pre-emergent herbicides used primarily on conventional canola, but also on other crops (i.e., triallate, ethalfluralin and trifluralin) have dropped in sales volume over the past 20 years, related in large part to the shift in herbicide tolerant canola varieties being seeded.

Triallate dropped from $693178 \mathrm{~kg}$ ai in 1998 to $101072 \mathrm{~kg}$ ai by 2008 , with ethalfluralin and 
trifluralin showing similar reductions. On the other hand, glyphosate increased significantly each reporting period, going from 2.7 million $\mathrm{kg}$ ai in 1998 to 6.1 million $\mathrm{kg}$ ai by 2008 (Appendix 2).

While not all of the glyphosate sales can be directly attributed to changes in canola cropping practices, the shift to glyphosate tolerant canola has had a major influence on glyphosate usage. In addition to glyphosate tolerant canola influencing glyphosate sales, producers also adopted zero-tillage practices throughout the 1990's and 2000's, using glyphosate for pre-seeding weed control instead of tillage. Additionally, some of the increase in glyphosate use can be attributed to other changes in farming practices such as the decline in tillage in favour of 'chemfallow', and the use of glyphosate for in-crop weed control prior to harvest.

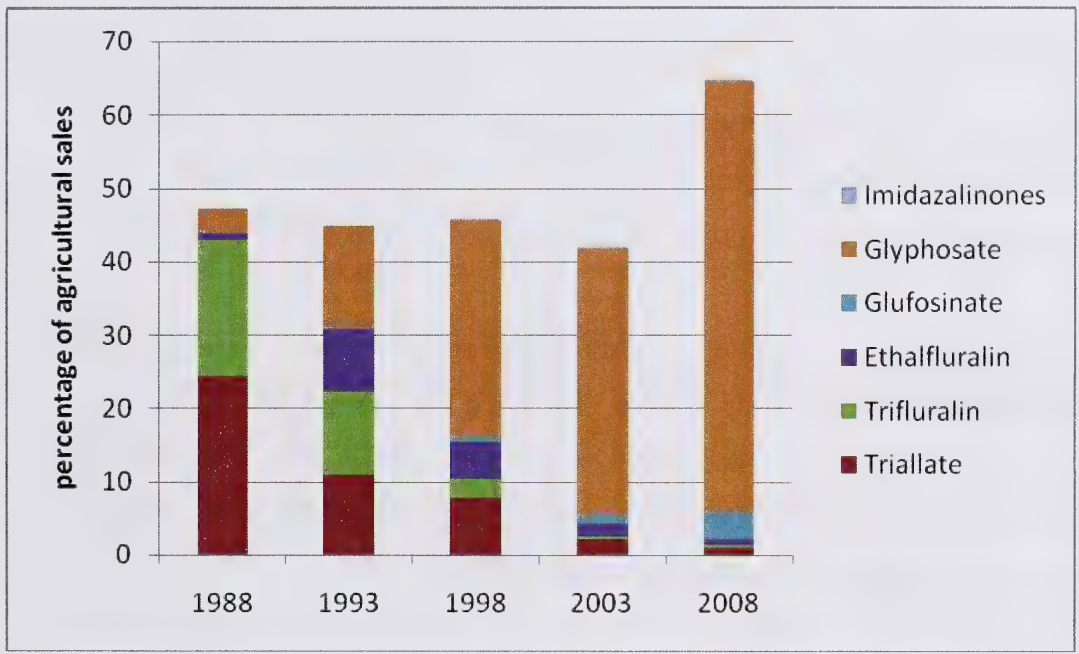

Figure 9. Selected Canola Herbicide Sales (1988-2008)

\subsection{Agricultural Insecticides}

Agricultural insecticide use fluctuates considerably from year to year. Insect outbreaks characterized 1998 (Lygus bug) and 2003 (grasshopper) insecticide sales. Insect pest pressures were considerably less in 2008.

In 2008, insecticides accounted for only $1.6 \% \%$ of all agricultural use, and chlorpyrifos made up $44 \%$ of that volume. Chlorpyrifos and carbaryl were the two insecticides with the largest sales in 2003. However, chlorpyrifos sales dropped from $197765 \mathrm{~kg}$ ai in 2003 to $82729 \mathrm{~kg}$ ai in 2008 . Carbaryl sales dropped from $104430 \mathrm{~kg}$ ai in 2003 to $9787 \mathrm{~kg}$ ai in 2008. 
In 1998, high sales volumes of chlorpyrifos (217 $397 \mathrm{~kg}$ ai) were also reported because of an outbreak of Lygus bug which required spraying of 1.4 M acres for this pest species (Byrtus 2000).

\subsection{Spatial Data}

The pesticide sales data was sorted in a number of ways to provide some spatial perspective. The spatial sorts were done by municipality, by natural region, by Land Use Framework region, and by drainage basin. The municipality level was the highest level of resolution attempted, with over 60 polygons involved. Problems in interpreting data at this scale are that vendors are not evenly distributed amongst municipalities, with some major distribution centres (e.g., Lethbridge, Medicine Hat) influencing some of the spatial interpretation of the data.

At the river basin scale, there are fewer polygons involved, resulting in slightly better confidence in the spatial assessment. For water quality monitoring purposes, the breakdown of pesticide sales by river basin is a useful tool in determining monitoring priorities. A detailed breakdown on pesticide sales by active ingredient and river basin is outlined in Appendix 4

Changes in pesticide sales were consistent over most of the geographical areas between 2003 and 2008, with most comparable areas going up in sales. The Land Use Framework regions are a new regional context to assess pesticide sales, and with $82 \%$ of total pesticide sales in three of the seven regions (North Saskatchewan, Red Deer, and South Saskatchewan), this reflects on the large amount of agricultural inputs used in this part of the province. 


\subsection{CONCLUSIONS}

The overview of 2008 pesticide sales data provides a general background for assessing pesticide management programs and pesticide monitoring programs. Product breakdowns and regional distributions are comparable to results observed in 2003, although increasing utilization of the active ingredient glyphosate was again observed, similar to the observation made in 2003.

Key results of the 2008 survey are:

- Total sales volume was almost $\mathbf{1 2 . 5}$ million $\mathrm{kg}$ of active ingredient.

- Herbicides and plant growth regulators made up $\mathbf{8 2 . 2 \%}$ of the total volume sold.

- Of the chemical groups, the Phosphonic/Phosphinic Acid group had the highest sales, comprising $\mathbf{5 3 . 2} \%$ of total pesticide sales.

- From this chemical group, glyphosate sales accounted for 6.2 million $\mathrm{kg}$ ai, $50 \%$ of total sales and an $84 \%$ increase over 2003 .

- The Agriculture sector accounted for $\mathbf{9 6 . 5 \%}$ of all pesticides sold in Alberta, with $82 \%$ of that being herbicides, and $3 \%$ being fungicides.

- The Commercial/Industrial sector accounted for 3.1\% of all pesticides sold in Alberta, with herbicides making up $90 \%$ and fungicides $5 \%$.

- The Domestic sector accounted for $\mathbf{0 . 7 \%}$ of total pesticide sales, with herbicides making up $68 \%$ and insecticides $27.5 \%$.

- Spatially, the Oldman, Red Deer, North Saskatchewan, Battle and Peace River basins each had over 1 million $\mathrm{kg}$ ai of pesticide sales.

- The South Saskatchewan River Land Use Framework region had the highest proportion of pesticide sales at over $\mathbf{4 0 \%}$. The Lower Athabasca region had the lowest proportion of sales at $\mathbf{0 . 6 \%}$ of pesticide sales.

- The Central Parkland natural region had the largest volume of sales by natural region, at just under 4 million $\mathrm{kg}$ ai.

- Average agricultural pesticide use intensity for Alberta was estimated at $\mathbf{1 . 0 2} \mathrm{kg}$ ai/ha. 
AARD. 2009. 2006 Census of Agriculture for Alberta. I.D., M.D., and County Data by Region. Alberta Agriculture and Rural Development, Statistics and Data Development, Agdex 852-1. Edmonton. 165 pp.

AAF. 2008. Crop Protection 2008. Agdex 606-1. Alberta Agriculture and Food. Edmonton. 532 pp.

AAFRD. 2003. Canada-Alberta Environmentally Sustainable Agriculture Agreement (CAESA): Soil Inventory Project Procedures Manual - Data Dictionary. Alberta Agriculture, Food and Rural Development. Published online February 2003 (wwwl.agric.gov.ab.ca)

Alberta Canola Producers Commission. 2003. ACPC Annual Report 2002-03. Edmonton, 56 pp

Alberta Canola Producers Commission, 2009. ACPC Annual Report 2008-2009. Edmonton, 48 pp.

Anderson, A-M. 2005. Overview of Pesticide Data in Alberta Surface Waters Since 1995. Alberta Environment, Monitoring and Evaluation Branch, Edmonton, 172 pp.

Brimble, S., P. Bacchus and P.-Y. Caux. 2005. Pesticide Utilization in Canada: A Compilation of Current Sales and Use Data. Environment Canada. Ottawa. 144 pp.

Byrtus, G. 2000. Overview of 1998 Pesticide Sales in Alberta. Alberta Environment. Edmonton. $58 \mathrm{pp}$.

Byrtus, G. 2007. Overview of 2003 Pesticide Sales in Alberta. Alberta Environment. Edmonton. $60 \mathrm{pp}$.

Canola Council of Canada. 2010. Canadian Canola Supply and Acreage-Herbicide Tolerant and Conventional Canola- accessed February 19, 2011. http://www.canolacouncil.org/ht_conventional_estimates.aspx

Cotton, M.M. and G. Byrtus. 1995. Pesticide Sales Trends in Alberta. Appendix A2. 66 pp in Cross, P. et al. Phase 2. Selection of Soil Landscape Units and Study Design Considerations for the Surface Water Quality Monitoring Program. Prepared for CAESA Water Quality Monitoring Committee. Edmonton.

CAESA. 1998. Agricultural Impact on Water Quality in Alberta: An Initial Assessment. Prepared for Canada-Alberta Environmentally sustainable Agriculture Water Quality Committee. Alberta Agriculture, Food and Rural Development. Lethbridge. 95 pp.

Dion, S. 2007. Guide de classement des ingredients actifs par groups chimiques, Quebec ministere du Developpement durable, de l'Environnement et des Parcs, 35 pp.

Ecological Stratification Working Group. 1995. A National Ecological Framework for Canada. Agriculture and Agri-Food Canada, Research Branch, Centre for Land and Biological Resources Research and Environment Canada, State of the Environment Directorate, 
Ecozone Analysis Branch, Ottawa/Hull. 121 pp report and national map at 1:7 500000 scale.

Gregoire, F. 1997. Overview of 1995 Pesticide Sales in Quebec. Quebec Department of Environment and Wildlife, Pesticides Division. $19 \mathrm{pp}$.

Gorse, I. and S. Dion. 2010. Bilan des ventes de pesticides au Quebec pour l'annee 2007. Ministere du Developpement durable, de l'Environnement et des Parcs, $81 \mathrm{pp}$.

Grube, A., D. Donaldson, T. Kiely and L. Wu 2011. Pesticides Industry Sales and Usage. 2006 and 2007 Market Estimates. United States Environmental Protection Agency. Office of Pesticide Programs. Report 733-R-11-001. Washington, D.C. 33 pp.

Hartmann, M. 2005. Alberta Agriculture and Food. Personal communication.

Land Use Secretariat. 2008. Land-Use Framework. Government of Alberta. Edmonton. 54 pp.

Pekalski, B. 1995. A Historical Series of Agricultural Statistics for Alberta: Selected Statistics from the Census of Agriculture. Alberta Agriculture, Food and Rural Development, Market Analysis and Statistics Branch. Edmonton, AB 33 pp.

Spiess, D. 2005. Alberta Agriculture and Food, Resource Data Management Unit. Personal communication.

Strong, W.L. and J.M. Thompson. 1995. Ecodistricts of Alberta: Summary of Biophysical Attributes. Prepared for Alberta Environmental Protection, Edmonton. 92 pp. + maps. 
Appendix 1. Chemical Groups and Active Ingredients - 2008

\begin{tabular}{|c|c|c|}
\hline CHEMICAL GROUP & ACTIVE INGREDIENT NAME & $\begin{array}{l}\text { TYPE OF } \\
\text { USE }\end{array}$ \\
\hline \multirow[t]{6}{*}{ Acylureas } & BENTAZON & Herbicide \\
\hline & BROMACIL & Herbicide \\
\hline & DIFLUBENZURON & Insecticide \\
\hline & HEXAZINONE & Herbicide \\
\hline & IPRODIONE & Fungicide \\
\hline & TERBACIL & Herbicide \\
\hline \multirow[t]{4}{*}{ Alcohols } & BUTOXYPOLYPROPYLENE GLYCOL & Insecticide \\
\hline & CHOLECALCIFEROL & Vertebrate \\
\hline & P-MENTHANE-3, 8-DIOL & Insecticide \\
\hline & SILOXYLATED POLYETHER & Adjuvant \\
\hline \multirow{2}{*}{ Aldehydes } & FORMALDEHYDE & Fungicide \\
\hline & METALDEHYDE & Insecticide \\
\hline \multirow[t]{4}{*}{ Amides } & CAPSAICIN (OLEORESIN CAPSICUM) & Vertebrate \\
\hline & DAMINOZIDE & $\begin{array}{l}\text { Plant Growth } \\
\text { Regulator }\end{array}$ \\
\hline & NAPROPAMIDE & Herbicide \\
\hline & PIPERINE & Vertebrate \\
\hline \multirow[t]{7}{*}{ Ammoniums, Quaternary } & CHLORMEQUAT & $\begin{array}{l}\text { Plant Growth } \\
\text { Regulator }\end{array}$ \\
\hline & DENATONIUM BENZOATE & Vertebrate \\
\hline & $\begin{array}{l}\text { DIDECYL DIMETHYL AMMONIUM } \\
\text { CHLORIDE }\end{array}$ & Disinfectant \\
\hline & DIFENZOQUAT & Herbicide \\
\hline & DIQUAT & Herbicide \\
\hline & $\begin{array}{l}\text { N-ALKYL DIMETHYL BENZYL AMMONIUM } \\
\text { CHLORIDE }\end{array}$ & Disinfectant \\
\hline & PARAQUAT & Herbicide \\
\hline \multirow[t]{6}{*}{ Anilides } & BOSCALID & Fungicide \\
\hline & FENHEXAMID & Fungicide \\
\hline & METALAXYL & Fungicide \\
\hline & METALAXYL-M & Fungicide \\
\hline & PROPANIL & Herbicide \\
\hline & S-METOLACHLOR & Herbicide \\
\hline \multirow[t]{6}{*}{ Aryloxyphenoxyl Acids } & CLODINAFOP-PROPARGYL & Herbicide \\
\hline & DICLOFOP-METHYL & Herbicide \\
\hline & FENOXAPROP-P-ETHYL (ISOMER) & Herbicide \\
\hline & FLUAZIFOP-P-BUTYL & Herbicide \\
\hline & QUIZALOFOP P-ETHYL & Herbicide \\
\hline & QUIZALOFOP-ETHYL & Herbicide \\
\hline \multirow[t]{7}{*}{ Azoles, Oxazoles, Thiazoles } & ETRIDIAZOLE & Fungicide \\
\hline & FLUDIOXONIL & Fungicide \\
\hline & PINOXADEN & Herbicide \\
\hline & PYRASULFOTOLE & Herbicide \\
\hline & SPIROTETRAMAT & Insecticide \\
\hline & STRYCHNINE & Vertebrate \\
\hline & THIABENDAZOLE & Fungicide \\
\hline
\end{tabular}




\begin{tabular}{|c|c|c|}
\hline CHEMICAL GROUP & ACTIVE INGREDIENT NAME & $\begin{array}{l}\text { TYPE OF } \\
\text { USE }\end{array}$ \\
\hline \multirow{4}{*}{ Benzamides } & DEET & Insecticide \\
\hline & ISOXABEN & Herbicide \\
\hline & PROPYZAMIDE & Herbicide \\
\hline & TEBUFENOZIDE & Insecticide \\
\hline \multirow{3}{*}{$\begin{array}{l}\text { Benzoic Acid \& } \\
\text { Derivatives }\end{array}$} & DICAMBA & Herbicide \\
\hline & OXINE BENZOATE & Fungicide \\
\hline & QUINCLORAC & Herbicide \\
\hline \multirow{3}{*}{ Benzonitriles } & BROMOXYNIL & Herbicide \\
\hline & CHLOROTHALONIL & Fungicide \\
\hline & DICHLOBENIL & Herbicide \\
\hline \multirow[t]{9}{*}{ Biscarbamates } & DESMEDIPHAM & Herbicide \\
\hline & FERBAM & Fungicide \\
\hline & MANCOZEB & Fungicide \\
\hline & MANEB & Fungicide \\
\hline & METIRAM & Fungicide \\
\hline & PHENMEDIPHAM & Herbicide \\
\hline & THIOPHANATE-METHYL & Fungicide \\
\hline & THIRAM & Fungicide \\
\hline & ZINEB & Fungicide \\
\hline \multirow[t]{9}{*}{ Carbamates } & BENDIOCARB & Insecticide \\
\hline & BIFENAZATE & Insecticide \\
\hline & CARBARYL & Insecticide \\
\hline & CARBOFURAN & Insecticide \\
\hline & CHLORPROPHAM & Herbicide \\
\hline & OXADIAZON & Herbicide \\
\hline & PROPAMOCARB HYDROCHLORIDE & Fungicide \\
\hline & PROPOXUR & Insecticide \\
\hline & VINCLOZOLIN & Fungicide \\
\hline \multirow[t]{3}{*}{ Chlorotriazines } & ATRAZINE & Herbicide \\
\hline & PYMETROZINE & Insecticide \\
\hline & SIMAZINE & Herbicide \\
\hline \multirow[t]{5}{*}{ Chromenones } & BRODIFACOUM & Vertebrate \\
\hline & BROMADIOLONE & Vertebrate \\
\hline & DIFETHIALONE & Vertebrate \\
\hline & ROTENONE & Insecticide \\
\hline & WARFARIN & Vertebrate \\
\hline \multirow[t]{4}{*}{ Cyclohexanedione oximes } & CLETHODIM & Herbicide \\
\hline & SETHOXYDIM & Herbicide \\
\hline & TEPRALOXYDIM & Herbicide \\
\hline & TRALKOXYDIM & Herbicide \\
\hline \multirow[t]{5}{*}{ Diazines } & ANCYMIDOL & $\begin{array}{l}\text { Plant Growth } \\
\text { Regulator }\end{array}$ \\
\hline & MALEIC HYDRAZIDE & $\begin{array}{l}\text { Plant Growth } \\
\text { Regulator }\end{array}$ \\
\hline & PYRAZON & Herbicide \\
\hline & PYRIDABEN & Insecticide \\
\hline & SULFAQUINOXALINE & Vertebrate \\
\hline
\end{tabular}




\begin{tabular}{|c|c|c|}
\hline CHEMICAL GROUP & ACTIVE INGREDIENT NAME & $\begin{array}{l}\text { TYPE OF } \\
\text { USE }\end{array}$ \\
\hline \multirow[t]{4}{*}{ Dinitrobenzenes } & BROMETHALIN & Vertebrate \\
\hline & ETHALFLURALIN & Herbicide \\
\hline & PENDIMETHALIN & Herbicide \\
\hline & TRIFLURALIN & Herbicide \\
\hline Dithiocarbamates & DAZOMET & Soil \\
\hline \multirow[t]{7}{*}{ Dithiophosphates } & AZINPHOS-METHYL & Insecticide \\
\hline & DIMETHOATE & Insecticide \\
\hline & MALATHION & Insecticide \\
\hline & PHORATE & Insecticide \\
\hline & PHOSALONE & Insecticide \\
\hline & PHOSMET & Insecticide \\
\hline & TERBUFOS & Insecticide \\
\hline \multirow[t]{13}{*}{ Fatty Acids \& Surfactants } & FATTY ACID & Herbicide \\
\hline & METHYLATED CANOLA OIL & Adjuvant \\
\hline & NONYLPHENOXYPOLYETHOXYETHANOL & Adjuvant \\
\hline & OCTYLPHENOXYPOLYETHOXYETHANOL & Adjuvant \\
\hline & $\begin{array}{l}\text { PARAFFIN BASE MINERAL OIL } \\
\text { (ADJUVANT) }\end{array}$ & Adjuvant \\
\hline & PARAFFIN BASE PETROLEUM OIL & Adjuvant \\
\hline & $\begin{array}{l}\text { POLYOXYALKYLATED ALKYL PHOSPHATE } \\
\text { ESTER }\end{array}$ & Adjuvant \\
\hline & POTASSIUM SALTS OF FATTY ACIDS & Insecticide \\
\hline & SAFER'S INSECTICIDAL SOAP & Insecticide \\
\hline & SOAP (INSECTICIDAL) & Insecticide \\
\hline & SOAP (HERBICIDAL) & Herbicide \\
\hline & SURFACTANT BLEND & Adjuvant \\
\hline & SURFACTANT MIXTURE & Adjuvant \\
\hline \multirow[t]{5}{*}{ Guanidines } & CLOTHIANIDIN & Insecticide \\
\hline & CYPRODINIL & Fungicide \\
\hline & HYDRAMETHYLNON & Insecticide \\
\hline & IMIDACLOPRID & Insecticide \\
\hline & THIAMETHOXAM & Insecticide \\
\hline \multirow{3}{*}{$\begin{array}{l}\text { Halogenated Organic } \\
\text { Acids }\end{array}$} & AMINOPYRALID & Herbicide \\
\hline & CLOPYRALID & Herbicide \\
\hline & PICLORAM & Herbicide \\
\hline \multirow[t]{3}{*}{ Hydrocarbons } & ASPHALT SOLIDS & Fungicide \\
\hline & NAPHTHALENE & Insecticide \\
\hline & PETROLEUM HYDROCARBON BLEND & Adjuvant \\
\hline \multirow[t]{5}{*}{ Imidazolinones } & FENAMIDONE & Fungicide \\
\hline & IMAZAMETHABENZ & Herbicide \\
\hline & IMAZAMOX & Herbicide \\
\hline & IMAZETHAPYR & Herbicide \\
\hline & IMAZAPYR & Herbicide \\
\hline \multirow[t]{2}{*}{ Indanediones } & CHLOROPHACINONE & Vertebrate \\
\hline & DIPHACINONE & Vertebrate \\
\hline \multirow[t]{2}{*}{ Inorganic Coppers } & COPPER (CUPRIC) HYDROXIDE & Fungicide \\
\hline & COPPER NAPHTHENATE & Wood \\
\hline
\end{tabular}




\begin{tabular}{|c|c|c|}
\hline CHEMICAL GROUP & ACTIVE INGREDIENT NAME & $\begin{array}{l}\text { TYPE OF } \\
\text { USE }\end{array}$ \\
\hline & COPPER OXYCHLORIDE & Fungicide \\
\hline & COPPER SULPHATE & Fungicide \\
\hline & COPPER SULPHATE TRIBASIC & Fungicide \\
\hline \multirow[t]{2}{*}{ Inorganic Zincs } & ZINC NAPHTHENATE & Wood \\
\hline & ZINC PHOSPHIDE & Vertebrate \\
\hline \multirow[t]{15}{*}{ Inorganics, Other } & ALUMINUM PHOSPHIDE & Insecticide \\
\hline & AMMONIA & Vertebrate \\
\hline & BORACIC ACID & Insecticide \\
\hline & BORAX & Insecticide \\
\hline & FERRIC PHOSPHATE & Insecticide \\
\hline & FERROUS SULFATE & Herbicide \\
\hline & FOSETYL-AL & Fungicide \\
\hline & LIME SULPHUR & Fungicide \\
\hline & POTASSIUM MONOPERSULPHATE & Disinfectant \\
\hline & SILICA AEROGEL & Insecticide \\
\hline & SILICON DIOXIDE FRESH WATER FOSSILS & Insecticide \\
\hline & SILICON DIOXIDE SALT WATER FOSSILS & Insecticide \\
\hline & SULPHUR (FUNGICIDE) & Fungicide \\
\hline & SULPHUR (INSECTICIDE) & Insecticide \\
\hline & SULPHUR (VERTEBRATE CONTROL) & Vertebrate \\
\hline \multirow[t]{3}{*}{ Methoxyacrylates } & AZOXYSTROBIN & Fungicide \\
\hline & PYRACLOSTROBIN & Fungicide \\
\hline & TRIFLOXYSTROBIN & Fungicide \\
\hline \multirow[t]{7}{*}{ Microbials } & BACILLUS SPHAERICUS & Insecticide \\
\hline & BACILLUS SUBTILIS & Insecticide \\
\hline & BACILLUS THURINGIENSIS SSP KURSTAKI & Insecticide \\
\hline & BACILLUS THURINGIENSIS, SEROTYPE H-14 & Insecticide \\
\hline & GLIOCLADIUM CATENULATUM & Fungicide \\
\hline & STREPTOMYCES GRISEOVIRIDIS & Fungicide \\
\hline & STREPTOMYCES LYDICUS & Fungicide \\
\hline \multirow{13}{*}{$\begin{array}{l}\text { Miscellaneous (Non- } \\
\text { Classified) }\end{array}$} & 1-OCTEN-3-OL & Insecticide \\
\hline & ACROLEIN & Herbicide \\
\hline & BISPYRIBAC & Herbicide \\
\hline & BRONOPOL & Preservative \\
\hline & CORN GLUTEN MEAL & Herbicide \\
\hline & DRIED BLOOD & Vertebrate \\
\hline & ETHOFUMESATE & Herbicide \\
\hline & METHYL NONYL KETONE & Vertebrate \\
\hline & NATURAL GUM RESINS & Insecticide \\
\hline & PIPERONYL BUTOXIDE & Insecticide \\
\hline & PUTRESCENT WHOLE EGG SOLIDS & Vertebrate \\
\hline & SODIUM ALPHA-OLEFIN SULFONATE & Adjuvant \\
\hline & WATER SOLUBLE DYES & Herbicide \\
\hline \multirow[t]{3}{*}{ Morpholines \& Oxathiines } & CARBATHIIN & Fungicide \\
\hline & DIMETHOMORPH & Fungicide \\
\hline & DODEMORPH-ACETATE & Fungicide \\
\hline
\end{tabular}




\begin{tabular}{|c|c|c|}
\hline CHEMICAL GROUP & ACTIVE INGREDIENT NAME & $\begin{array}{l}\text { TYPE OF } \\
\text { USE }\end{array}$ \\
\hline & OXYCARBOXIN & Fungicide \\
\hline \multirow[t]{3}{*}{ Nitrobenzenes } & MESOTRIONE & Fungicide \\
\hline & OXYFLUORFEN & Herbicide \\
\hline & QUINTOZENE & Fungicide \\
\hline \multirow{3}{*}{$\begin{array}{l}\text { Oils, Mineral and } \\
\text { Vegetable }\end{array}$} & ARTIFICIAL ESSENTIAL OIL BLEND & Insecticide \\
\hline & $\begin{array}{l}\text { MINERAL OIL (INSECTICIDAL OR } \\
\text { ADJUVANT) }\end{array}$ & Insecticide \\
\hline & OIL OF BLACK PEPPER & Vertebrate \\
\hline \multirow[t]{9}{*}{ Organic Acids } & ABAMECTIN & Insecticide \\
\hline & ACEQUINOCYL & Insecticide \\
\hline & ACETIC ACID & Herbicide \\
\hline & FERRIC SODIUM EDTA & Insecticide \\
\hline & GIBBERELLIC ACID & $\begin{array}{l}\text { Plant Growth } \\
\text { Regulator }\end{array}$ \\
\hline & SPINETORAM & Insecticide \\
\hline & SPINOSAD FACTOR A PLUS & Insecticide \\
\hline & SPIROMESIFEN & Insecticide \\
\hline & TRINEXAPAC-ETHYL & $\begin{array}{l}\text { Plant Growth } \\
\text { Regulator }\end{array}$ \\
\hline \multirow{3}{*}{ Organochlorines } & DICOFOL & Insecticide \\
\hline & ENDOSULFAN & Insecticide \\
\hline & PARADICHLOROBENZENE & Insecticide \\
\hline Organohalogens & METHYL BROMIDE & Insecticide \\
\hline Organometallics & FENBUTATIN OXIDE & Insecticide \\
\hline \multirow[t]{2}{*}{ Oximes-Carbamates } & METHOMYL & Insecticide \\
\hline & OXAMYL & Insecticide \\
\hline \multirow[t]{9}{*}{ Phenoxy Acids } & $2,4-\mathrm{D}$ & Herbicide \\
\hline & 2,4-DB & Herbicide \\
\hline & 4-CPA & $\begin{array}{l}\text { Plant Growth } \\
\text { Regulator }\end{array}$ \\
\hline & DICHLORPROP (2,4-DP) & Herbicide \\
\hline & MCPA & Herbicide \\
\hline & MCPB & Herbicide \\
\hline & MECOPROP (D-ISOMER) & Herbicide \\
\hline & MECOPROP-P & Herbicide \\
\hline & TRICLOPYR & Herbicide \\
\hline \multirow[t]{4}{*}{ Pheromones } & GERMAN COCKROACH EXTRACT & Insecticide \\
\hline & KINOPRENE & Insecticide \\
\hline & METHOPRENE & Insecticide \\
\hline & Z-9-TRICOSENE & Insecticide \\
\hline \multirow[t]{2}{*}{ Phosphates } & DICHLORVOS & Insecticide \\
\hline & NALED & Insecticide \\
\hline \multirow{3}{*}{$\begin{array}{l}\text { Phosphonic Acids, } \\
\text { Phosphinic Acids }\end{array}$} & ETHEPHON & $\begin{array}{l}\text { Plant Growth } \\
\text { Regulator }\end{array}$ \\
\hline & GLUFOSINATE AMMONIUM & Herbicide \\
\hline & GLYPHOSATE & Herbicide \\
\hline \multirow[t]{2}{*}{ Phosphoramidothioates } & ACEPHATE & Insecticide \\
\hline & METHAMIDOPHOS & Insecticide \\
\hline
\end{tabular}




\begin{tabular}{|c|c|c|}
\hline CHEMICAL GROUP & ACTIVE INGREDIENT NAME & $\begin{array}{l}\text { TYPE OF } \\
\text { USE }\end{array}$ \\
\hline & PROPETAMPHOS & Insecticide \\
\hline \multirow[t]{4}{*}{ Phthalic Acids } & CAPTAN & Fungicide \\
\hline & FOLPET & Fungicide \\
\hline & $\begin{array}{l}\text { N-OCTYL BICYCLOHEPTENE } \\
\text { DICARBOXIMIDE }\end{array}$ & Insecticide \\
\hline & PROTHIOCONAZOLE & Fungicide \\
\hline \multirow[t]{12}{*}{ Pyrethroids, Pyrethrins } & CYFLUTHRIN & Insecticide \\
\hline & CYHALOTHRIN-LAMBDA & Insecticide \\
\hline & CYPERMETHRIN & Insecticide \\
\hline & D-CIS ALLETHRIN & Insecticide \\
\hline & D-CIS, TRANS ALLETHRIN & Insecticide \\
\hline & DELTAMETHRIN & Insecticide \\
\hline & D-PHENOTHRIN & Insecticide \\
\hline & D-TRANS ALLETHRIN & Insecticide \\
\hline & PERMETHRIN & Insecticide \\
\hline & PYRETHRINS & Insecticide \\
\hline & RESMETHRIN & Insecticide \\
\hline & TETRAMETHRIN & Insecticide \\
\hline \multirow[t]{6}{*}{ Pyridines } & 4-AMINOPYRIDINE & Vertebrate \\
\hline & ACETAMIPRID & Insecticide \\
\hline & DI-N-PROPYL ISOCINCHOMERONATE & Insecticide \\
\hline & FLUROXYPYR 1-METHYLHEPTYL ESTER & Herbicide \\
\hline & NICOTINE & Insecticide \\
\hline & PYRIPROXYFEN & Insecticide \\
\hline \multirow[t]{11}{*}{ Sulfonylureas } & CHLORSULFURON & Herbicide \\
\hline & ETHAMETSULFURON-METHYL & Herbicide \\
\hline & FLUCARBAZONE SODIUM & Herbicide \\
\hline & METSULFURON-METHYL & Herbicide \\
\hline & NICOSULFURON & Herbicide \\
\hline & RIMSULFURON & Herbicide \\
\hline & SULFOSULFURON & Herbicide \\
\hline & THIFENSULFURON METHYL & Herbicide \\
\hline & TRIASULFURON & Herbicide \\
\hline & TRIBENURON METHYL & Herbicide \\
\hline & TRIFLUSULFURON METHYL & Herbicide \\
\hline \multirow[t]{2}{*}{ Thiocarbamates } & EPTC & Herbicide \\
\hline & TRIALLATE & Herbicide \\
\hline \multirow[t]{3}{*}{ Thiophosphates } & CHLORPYRIFOS & Insecticide \\
\hline & DIAZINON & Insecticide \\
\hline & FENTHION & Insecticide \\
\hline \multirow[t]{3}{*}{ Triazines, Tetrazines } & CYROMAZINE & Insecticide \\
\hline & METRIBUZIN & Herbicide \\
\hline & PROMETRYNE & Herbicide \\
\hline \multirow[t]{4}{*}{ Triazoles } & AMITROLE & Herbicide \\
\hline & DIFENOCONAZOLE & Fungicide \\
\hline & FLORASULAM & Herbicide \\
\hline & MYCLOBUTANIL & Fungicide \\
\hline
\end{tabular}




\begin{tabular}{|l|l|l|}
\hline \multirow{4}{*}{ CHEMICAL GROUP } & ACTIVE INGREDIENT NAME & $\begin{array}{l}\text { TYPE OF } \\
\text { USE }\end{array}$ \\
\hline \multirow{5}{*}{ PACLOBUTRAZOL } & $\begin{array}{l}\text { Plant Growth } \\
\text { Regulator }\end{array}$ \\
\cline { 2 - 3 } & PROPICONAZOLE & Fungicide \\
\cline { 2 - 3 } & PYROXSULAM & Herbicide \\
\cline { 2 - 3 } & TEBUCONAZOLE & Fungicide \\
\cline { 2 - 3 } & TRITICONAZOLE & Fungicide \\
\cline { 2 - 3 } & UNICONAZOLE-P & $\begin{array}{l}\text { Plant Growth } \\
\text { Regulator }\end{array}$ \\
\hline Urea Derivatives & CARFENTRAZONE-ETHYL & Herbicide \\
\cline { 2 - 3 } & DIURON & Herbicide \\
\cline { 2 - 3 } & LINURON & Herbicide \\
\hline
\end{tabular}




\section{Appendix 2. Alberta (2008) and Quebec (2007) Pesticide Sales by Chemical Group}

\begin{tabular}{|c|c|c|c|c|}
\hline Active Ingredient & Alberta kg ai & $\%$ & Quebec kg ai & $\%$ \\
\hline Phosphonic Acids, Phosphinic Acids & 6633567.6 & 53.2 & 1025632 & 26.3 \\
\hline Phenoxy Acids & 2130654.7 & 17.1 & 212920 & 5.5 \\
\hline Fatty Acids \& Surfactants & 924680.7 & 7.4 & 147748 & 3.8 \\
\hline Hydrocarbons & 659521.1 & 5.3 & 168565 & 4.3 \\
\hline Benzonitriles & 366443.3 & 2.9 & 107246 & 2.7 \\
\hline Cyclohexanedione oximes & 191948.1 & 1.5 & 2702 & 0.1 \\
\hline Dinitrobenzenes & 118607.6 & 1.0 & 34270 & 0.9 \\
\hline Thiocarbamates & 112096.2 & 0.9 & 9848 & 0.3 \\
\hline Imidazolinones & 111806.9 & 0.9 & 5862 & 0.2 \\
\hline Aryloxyphenoxyl Acids & 110792.2 & 0.9 & 5512 & 0.1 \\
\hline Triazoles & 104706.9 & 0.8 & 4557 & 0.1 \\
\hline Biscarbamates & 102813.6 & 0.8 & 557420 & 14.3 \\
\hline Benzoic Acid \& Derivatives & 94908.1 & 0.8 & 36970 & 0.9 \\
\hline Halogenated Organic Acids & 88074.6 & 0.7 & 14739 & 0.4 \\
\hline Acylureas & 85612.4 & 0.7 & 58336 & 1.5 \\
\hline Thiophosphates & 85271.0 & 0.7 & 27638 & 0.7 \\
\hline Pyridines & 72411.4 & 0.6 & 999 & 0.0 \\
\hline Inorganics, Other & 64911.7 & 0.5 & 137419 & 3.5 \\
\hline Dithiophosphates & 57202.3 & 0.5 & 38225 & 1.0 \\
\hline Urea Derivatives & 47686.2 & 0.4 & 29489 & 0.8 \\
\hline Azoles, Oxazoles, Thiazoles & 41280.5 & 0.3 & 51580 & 1.3 \\
\hline Ammoniums, Quaternary & 40722.8 & 0.3 & 39826 & 1.0 \\
\hline Sulfonylureas & 27844.2 & 0.2 & 9030 & 0.2 \\
\hline Phthalic Acids & 27137.5 & 0.2 & 80919 & 2.1 \\
\hline Anilides & 26918.2 & 0.2 & 152662 & 3.9 \\
\hline Methoxyacrylates & 20532.1 & 0.2 & 4409 & 0.1 \\
\hline Miscellaneous (Non-Classified) & 18881.7 & 0.2 & 118743 & 3.0 \\
\hline Carbamates & 15688.9 & 0.13 & 31246 & 0.8 \\
\hline Morpholines \& Oxathiines & 15453.0 & 0.12 & 7735 & 0.2 \\
\hline Organic Acids & 12048.4 & 0.10 & 3887 & 0.1 \\
\hline Chlorotriazines & 10953.3 & 0.09 & 230358 & 5.9 \\
\hline Nitrobenzenes & 7627.0 & 0.06 & 31391 & 0.8 \\
\hline Guanidines & 6849.5 & 0.05 & 9446 & 0.2 \\
\hline Organohalogens & 6106.3 & 0.05 & 2294 & 0.1 \\
\hline Triazines, Tetrazines & 5919.3 & 0.05 & 9571 & 0.2 \\
\hline Alcohols & 5853.1 & 0.05 & 5471 & 0.1 \\
\hline Pyrethroids, Pyrethrins & 5717.9 & 0.05 & 9552 & 0.2 \\
\hline Inorganic Coppers & 4141.5 & 0.03 & & \\
\hline Oils, Mineral and Vegetable & 3925.8 & 0.03 & 156784 & 4.0 \\
\hline Benzamides & 1694.3 & 0.01 & 77649 & 2.0 \\
\hline Diazines & 1291.1 & 0.01 & 11730 & 0.3 \\
\hline Pheremones & 1274.0 & 0.01 & 8 & 0.00 \\
\hline Phosphates & 1077.6 & 0.01 & 5266 & 0.1 \\
\hline Organochlorines & 830.3 & 0.01 & 23183 & 0.6 \\
\hline
\end{tabular}




\begin{tabular}{|l|r|r|r|r|}
\hline Phosphoramidothioates & 626.2 & 0.01 & 5110 & 0.1 \\
\hline Aldehydes & 569.4 & 0.00 & 7955 & 0.2 \\
\hline Microbials & 420.4 & 0.00 & 2914 & 0.1 \\
\hline Dithiocarbamates & 392.0 & 0.00 & 171526 & 4.4 \\
\hline Amides & 270.9 & 0.00 & 7956 & 0.2 \\
\hline Inorganic Zincs & 179.8 & 0.00 & & \\
\hline Chromenones & 61.9 & 0.00 & 163 & 0.00 \\
\hline Oximes-Carbamates & 57.2 & 0.00 & 4955 & 0.1 \\
\hline Indanediones & 24.6 & 0.00 & 6 & 0.00 \\
\hline Organometallics & 8.6 & 0.00 & 17 & 0.00 \\
\hline Anilines & 0.0 & 0.00 & 499 & 0.01 \\
\hline Total & $\mathbf{1 2 4 7 6 \mathbf { 0 9 5 . 8 }}$ & $\mathbf{1 0 0 . 0}$ & $\mathbf{3 8 9 9 9 4 4}$ & $\mathbf{1 0 0 . 0}$ \\
\hline
\end{tabular}


Appendix 3. Alberta 1998, 2003 and 2008 Pesticide Sales by Active Ingredient

\begin{tabular}{|c|c|c|c|c|c|c|}
\hline $\begin{array}{l}\text { ACTIVE INGREDIENT } \\
\text { NAME }\end{array}$ & Type of use & $\begin{array}{l}2008 \text { total } \\
\text { (kg ai) }\end{array}$ & $\begin{array}{c}2008 \\
\%\end{array}$ & $\begin{array}{l}2003 \text { total } \\
\text { (kg ai) }\end{array}$ & $\begin{array}{c}2003 \\
\%\end{array}$ & $\begin{array}{l}1998 \text { total } \\
\text { (kg ai) }\end{array}$ \\
\hline GLYPHOSATE & Herbicide & 6235498.5 & 50.0 & 3419822.1 & 36.9 & 2682748.9 \\
\hline MCPA & Herbicide & 1028995.8 & 8.2 & 1097359.0 & 11.8 & 885239.1 \\
\hline $2,4-\mathrm{D}$ & Herbicide & 973082.3 & 7.8 & 763357.7 & 8.2 & 765820.4 \\
\hline $\begin{array}{l}\text { PETROLEUM HYDROCARBON } \\
\text { BLEND }\end{array}$ & Adjuvant & 656588.2 & 5.3 & 559728.7 & 6 & 368704.3 \\
\hline SURFACTANT BLEND & Adjuvant & 403438.3 & 3.2 & 438235.7 & 4.7 & 496561.7 \\
\hline GLUFOSINATE AMMONIUM & Herbicide & 395681.1 & 3.2 & 107255.5 & 1.2 & 63863.8 \\
\hline BROMOXYNIL & Herbicide & 330177.1 & 2.6 & 354906.6 & 3.8 & 268105.3 \\
\hline $\begin{array}{l}\text { PARAFFIN BASE MINERAL OIL } \\
\text { (ADJUVANT) }\end{array}$ & Adjuvant & 188738.7 & 1.5 & 192634.4 & 2.1 & 193162.6 \\
\hline METHYLATED CANOLA OIL & Adjuvant & 187385.6 & 1.5 & & & \\
\hline TRALKOXYDIM & Herbicide & 147916.9 & 1.2 & 141226.1 & 1.5 & 126323.5 \\
\hline TRIALLATE & Herbicide & 101072.2 & 0.8 & 197221.4 & 2.1 & 693178.5 \\
\hline DICAMBA & Herbicide & 94677.9 & 0.8 & 121422.7 & 1.3 & 138278.6 \\
\hline IMAZAMETHABENZ & Herbicide & 94004.3 & 0.8 & 138551.4 & 1.5 & 173679.2 \\
\hline ETHALFLURALIN & Herbicide & 82873.7 & 0.7 & 168135.0 & 1.8 & 452294.4 \\
\hline CHLORPYRIFOS & Insecticide & 82728.7 & 0.7 & 197765.5 & 2.1 & 217397.5 \\
\hline THIRAM & Fungicide & 76081.8 & 0.6 & 27136.3 & 0.29 & 22791.7 \\
\hline FLUROXYPYR & Herbicide & 71814.1 & 0.6 & 43166.7 & 0.47 & 23700.8 \\
\hline $\begin{array}{l}\text { NONYLPHENOXYPOLYETHOX } \\
\text { YETHANOL }\end{array}$ & Adjuvant & 58634.2 & 0.5 & 59558.8 & 0.64 & 94247.3 \\
\hline FENOXAPROP-P-ETHYL & Herbicide & 58399.7 & 0.5 & 64212.1 & 0.69 & 59919.0 \\
\hline CLOPYRALID & Herbicide & 58339.1 & 0.5 & 56618.0 & 0.61 & 59019.7 \\
\hline IPRODIONE & Fungicide & 57374.1 & 0.5 & 21014.3 & 0.23 & 9592.7 \\
\hline $\begin{array}{l}\text { POLYOXYALKYLATED ALKYL } \\
\text { PHOSPHATE ESTER }\end{array}$ & Adjuvant & 55943.9 & 0.4 & 13727.9 & 0.15 & 9340.0 \\
\hline DICHLORPROP & Herbicide & 52271.6 & 0.4 & 57450.1 & 0.62 & 40942.4 \\
\hline PROPICONAZOLE & Fungicide & 50387.5 & 0.4 & 13183.4 & 0.14 & 5664.4 \\
\hline CLODINAFOP-PROPARGYL & Herbicide & 46882.3 & 0.4 & 49520.8 & 0.53 & 34408.9 \\
\hline MECOPROP-P & Herbicide & 43319.9 & 0.3 & & & \\
\hline PHORATE & Insecticide & 40375.5 & 0.3 & 41417.3 & 0.45 & 19209.0 \\
\hline DIURON & Herbicide & 37674.4 & 0.3 & 31096.3 & 0.34 & 9919.3 \\
\hline CHLOROTHALONIL & Fungicide & 35693.8 & 0.3 & 43208.6 & 0.47 & 37334.0 \\
\hline DIQUAT & Herbicide & 34893.9 & 0.3 & 25524.4 & 0.28 & 21765.0 \\
\hline TRIFLURALIN & Herbicide & 34730.5 & 0.3 & 40654.3 & 0.44 & 230028.2 \\
\hline PINOXADEN & Herbicide & 32783.2 & 0.3 & & & \\
\hline PROTHIOCONAZOLE & Fungicide & 26517.0 & 0.2 & & & \\
\hline TRICLOPYR & Herbicide & 25678.1 & 0.2 & 33116.2 & 0.36 & 30311.8 \\
\hline SILICA AEROGEL & Insecticide & 25090.8 & 0.2 & 7785.0 & 0.08 & 11052.5 \\
\hline
\end{tabular}




\begin{tabular}{|c|c|c|c|c|c|c|}
\hline $\begin{array}{l}\text { ACTIVE INGREDIENT } \\
\text { NAME }\end{array}$ & Type of use & $\begin{array}{l}2008 \text { total } \\
\text { (kg ai) }\end{array}$ & $\begin{array}{c}2008 \\
\%\end{array}$ & $\begin{array}{l}2003 \text { total } \\
\text { (kg ai) }\end{array}$ & $\begin{array}{c}2003 \\
\%\end{array}$ & $\begin{array}{l}1998 \text { total } \\
\text { (kg ai) }\end{array}$ \\
\hline $\begin{array}{l}\text { PARAFFIN BASE PETROLEUM } \\
\text { OIL }\end{array}$ & Adjuvant & 22939.3 & 0.2 & 27958.4 & 0.3 & 77427.2 \\
\hline MANCOZEB & Fungicide & 22355.4 & 0.2 & 36127.2 & 0.39 & 45813.9 \\
\hline BOSCALID & Fungicide & 20519.8 & 0.2 & & & \\
\hline BENTAZON & Herbicide & 20481.0 & 0.2 & 21986.9 & 0.24 & 12066.2 \\
\hline CLETHODIM & Herbicide & 19955.8 & 0.2 & 3694.9 & 0.04 & 2490.7 \\
\hline SETHOXYDIM & Herbicide & 19194.1 & 0.2 & 30993.1 & 0.33 & 58678.5 \\
\hline PICLORAM & Herbicide & 25377.1 & 0.2 & 17897.0 & 0.19 & 15109.4 \\
\hline FLORASULAM & Herbicide & 15760.4 & 0.1 & 6090.5 & 0.07 & \\
\hline $\begin{array}{l}\text { SILICON DIOXIDE SALT } \\
\text { WATER FOSSILS }\end{array}$ & Insecticide & 15624.1 & 0.1 & 15588.2 & 0.17 & 47025.2 \\
\hline TEBUCONAZOLE & Fungicide & 15549.0 & 0.1 & 5922.4 & 0.06 & \\
\hline CARBATHIIN & Fungicide & 15231.1 & 0.1 & 45228.3 & 0.49 & 122292.0 \\
\hline DIFENOCONAZOLE & Fungicide & 13599.3 & 0.1 & 11067.6 & 0.12 & \\
\hline MALATHION & Insecticide & 13477.1 & 0.1 & 17413.8 & 0.19 & 22316.5 \\
\hline ACETIC ACID & Herbicide & 11915.6 & 0.10 & 1555.5 & 0.02 & \\
\hline $\begin{array}{l}\text { SULPHUR (VERTEBRATE } \\
\text { CONTROL) }\end{array}$ & Rodenticide & 11404.8 & 0.09 & 185.4 & 0 & 1045.3 \\
\hline EPTC & Herbicide & 11024.0 & 0.09 & 11944.0 & 0.13 & 38574.2 \\
\hline TRIBENURON METHYL & Herbicide & 9956.1 & 0.08 & 5404.8 & 0.06 & 6763.6 \\
\hline CARBARYL & Insecticide & 9787.3 & 0.08 & 104430.6 & 1.1 & 3142.8 \\
\hline ACROLEIN & Herbicide & 9051.0 & 0.07 & 16981.4 & 0.18 & 17520.5 \\
\hline THIFENSULFURON METHYL & Herbicide & 8344.1 & 0.07 & 8572.3 & 0.09 & 13697.5 \\
\hline FLUCARBAZONE SODIUM & Herbicide & 8333.0 & 0.07 & 2292.2 & 0.02 & \\
\hline TRIFLOXYSTROBIN & Fungicide & 7982.0 & 0.06 & & & \\
\hline FERROUS SULFATE & Herbicide & 7846.5 & 0.06 & 1593.4 & 0.02 & 1818.7 \\
\hline IMAZAMOX & Herbicide & 7773.9 & 0.06 & 3122.0 & 0.03 & 4231.8 \\
\hline PYRACLOSTROBIN & Fungicide & 7650.5 & 0.06 & 1263.6 & 0.01 & \\
\hline QUINTOZENE & Fungicide & 7528.8 & 0.06 & 7166.5 & 0.08 & 9808.9 \\
\hline LINURON & Herbicide & 7317.5 & 0.06 & 8991.4 & 0.1 & 8754 \\
\hline ETHOFUMESATE & Herbicide & 6518.4 & 0.05 & 7742.4 & 0.08 & 12559.4 \\
\hline PYRASULFOTOLE & Herbicide & 6323.6 & 0.05 & & & \\
\hline IMAZETHAPYR & Herbicide & 6195.7 & 0.05 & 5063.2 & 0.05 & 10528.6 \\
\hline ATRAZINE & Herbicide & 6172.7 & 0.05 & 4654.5 & 0.05 & 5753.8 \\
\hline METHYL BROMIDE & Insecticide & 6106.3 & 0.05 & & & \\
\hline THIAMETHOXAM & Insecticide & 5513.7 & 0.04 & 1176.2 & 0.01 & \\
\hline METRIBUZIN & Herbicide & 5061.1 & 0.04 & 6306.3 & 0.07 & 7601.4 \\
\hline VINCLOZOLIN & Fungicide & 4995.0 & 0.04 & 24324.3 & 0.26 & 25823.1 \\
\hline AMITROLE & Herbicide & 4994.4 & 0.04 & 2107.0 & 0.02 & 2026.5 \\
\hline AZOXYSTROBIN & Fungicide & 4899.6 & 0.04 & 1961.1 & 0.02 & \\
\hline TEPRALOXYDIM & Herbicide & 4881.3 & 0.04 & & & \\
\hline SIMAZINE & Herbicide & 4725.1 & 0.04 & 1160.4 & 0.01 & 3688.1 \\
\hline
\end{tabular}




\begin{tabular}{|c|c|c|c|c|c|c|}
\hline $\begin{array}{l}\text { ACTIVE INGREDIENT } \\
\text { NAME }\end{array}$ & Type of use & $\begin{array}{l}2008 \text { total } \\
\text { (kg ai) }\end{array}$ & $\begin{array}{c}2008 \\
\%\end{array}$ & $\begin{array}{l}2003 \text { total } \\
\text { (kg ai) }\end{array}$ & $\begin{array}{c}2003 \\
\%\end{array}$ & $\begin{array}{l}1998 \text { total } \\
\text { (kg ai) }\end{array}$ \\
\hline AMINOPYRALID & Herbicide & 4358.4 & 0.03 & & & \\
\hline METALAXYL-M & Fungicide & 4357.1 & 0.03 & 29813.1 & 0.32 & \\
\hline $\begin{array}{l}\text { BUTOXYPOLYPROPYLENE } \\
\text { GLYCOL }\end{array}$ & Insecticide & 4161.6 & 0.03 & 370.2 & 0 & 2.3 \\
\hline $\begin{array}{l}\text { OCTYLPHENOXYPOLYETHOX } \\
\text { YETHANOL }\end{array}$ & Adjuvant & 3920.6 & 0.03 & 5144.7 & 0.06 & 9219.0 \\
\hline $\begin{array}{l}\text { MINERAL OIL (INSECTICIDAL } \\
\text { OR ADJUVANT) }\end{array}$ & Insecticide & 3897.7 & 0.03 & 2233.7 & 0.02 & 3477.4 \\
\hline IMAZAPYR & Herbicide & 3828.1 & 0.03 & 1710.0 & 0.02 & 200.6 \\
\hline DIFENZOQUAT & Herbicide & 3792.0 & 0.03 & 4464.0 & 0.05 & 9585.5 \\
\hline QUIZALOFOP P-ETHYL & Herbicide & 3673.0 & 0.03 & 4461.0 & 0.05 & 2669.7 \\
\hline $2,4-\mathrm{DB}$ & Herbicide & 3640.0 & 0.03 & 11501.4 & 0.12 & 20950.3 \\
\hline HEXAZINONE & Herbicide & 3540.2 & 0.03 & 940.9 & 0.01 & 2428.1 \\
\hline MECOPROP-D & Herbicide & 3271.0 & 0.03 & 26080.4 & 0.28 & 27264.1 \\
\hline COPPER (CUPRIC) HYDROXIDE & Fungicide & 3192.6 & 0.03 & 6885.0 & 0.07 & 252.5 \\
\hline TRITICONAZOLE & Fungicide & 3145.2 & 0.03 & 2080.4 & 0.02 & \\
\hline CYHALOTHRIN-LAMBDA & Insecticide & 2947.5 & 0.02 & 5124.4 & 0.06 & 1097.9 \\
\hline CARFENTRAZONE-ETHYL & Herbicide & 2694.4 & 0.02 & & & \\
\hline DIAZINON & Insecticide & 2541.5 & 0.02 & 5149.9 & 0.06 & 4087.3 \\
\hline BROMACIL & Herbicide & 2486.9 & 0.02 & 4770.3 & 0.05 & 3106.9 \\
\hline ETHEPHON & Fungicide & 2388.0 & 0.02 & 115.2 & 0 & 31.2 \\
\hline NAPHTHALENE & Insecticide & 2318.2 & 0.02 & 118.5 & 0 & 1371.6 \\
\hline FLUAZIFOP-P-BUTYL & Herbicide & 1830.8 & 0.01 & 5808.5 & 0.06 & 12914.0 \\
\hline TERBUFOS & Insecticide & 1797.0 & 0.01 & 2893.0 & 0.03 & 6697.8 \\
\hline TERBACIL & Herbicide & 1728.0 & 0.01 & 332.8 & 0 & 891.2 \\
\hline PARAQUAT & Herbicide & 1727.6 & 0.01 & 1591.6 & 0.02 & 4820.4 \\
\hline SILOXYLATED POLYETHER & Adjuvant & 1690.2 & 0.01 & 1130.9 & 0.01 & \\
\hline PIPERONYL BUTOXIDE & Insecticide & 1607.3 & 0.01 & 405.1 & 0 & 591.6 \\
\hline SULPHUR (FUNGICIDE) & Fungicide & 1523.2 & 0.01 & 2968.1 & 0.03 & 7315.4 \\
\hline MANEB & Fungicide & 1521.5 & 0.01 & 3346.4 & 0.04 & 8462.0 \\
\hline DIMETHOATE & Insecticide & 1456.5 & 0.01 & 1691.1 & 0.02 & 4883.4 \\
\hline PERMETHRIN & Insecticide & 1402.7 & 0.01 & 315.8 & 0 & 397.2 \\
\hline SOAP & Insecticide & 1331.8 & 0.01 & 947.2 & 0.01 & \\
\hline SULPHUR (INSECTICIDE) & Insecticide & 1314.0 & 0.01 & 96.6 & 0 & 280.7 \\
\hline PYROXSULAM & Herbicide & 1251.4 & 0.01 & & & \\
\hline DEET & Insecticide & 1201.9 & 0.01 & 3413.3 & 0.04 & 4167.9 \\
\hline METALAXYL & Fungicide & 1164.1 & 0.009 & 302.2 & 0 & 3796.2 \\
\hline FLUDIOXONIL & Fungicide & 1100.6 & 0.009 & 24377.7 & 0.26 & \\
\hline Z-9-TRICOSENE & Insecticide & 1097.3 & 0.009 & 0.16 & 0 & 0.6 \\
\hline THIOPHANATE-METHYL & Fungicide & 1024.9 & 0.008 & 454.7 & 0 & 859.4 \\
\hline PENDIMETHALIN & Herbicide & 1003.2 & 0.008 & 782.8 & 0.01 & 1061.1 \\
\hline SAFER'S INSECTICIDAL SOAP & Insecticide & 902.0 & 0.007 & 1040.2 & 0.01 & 1641.6 \\
\hline
\end{tabular}




\begin{tabular}{|c|c|c|c|c|c|c|}
\hline $\begin{array}{l}\text { ACTIVE INGREDIENT } \\
\text { NAME }\end{array}$ & Type of use & $\begin{array}{l}2008 \text { total } \\
\text { (kg ai) }\end{array}$ & $\begin{array}{c}2008 \\
\%\end{array}$ & $\begin{array}{l}2003 \text { total } \\
\text { (kg ai) }\end{array}$ & $\begin{array}{c}2003 \\
\%\end{array}$ & $\begin{array}{l}1998 \text { total } \\
\text { (kg ai) }\end{array}$ \\
\hline MALEIC HYDRAZIDE & $\begin{array}{l}\text { Growth } \\
\text { Regulator }\end{array}$ & 867.8 & 0.007 & 1952.7 & 0.02 & 551.7 \\
\hline PROMETRYNE & Herbicide & 855.5 & 0.007 & 586.3 & 0.01 & \\
\hline S-METOLACHLOR & Herbicide & 830.9 & 0.007 & 3278.9 & 0.04 & \\
\hline NALED & Insecticide & 823.0 & 0.007 & 972.6 & 0.01 & 1257.9 \\
\hline CORN GLUTEN MEAL & Herbicide & 705.6 & 0.006 & & & \\
\hline $\begin{array}{l}\text { POTASSIUM SALTS OF FATTY } \\
\text { ACIDS }\end{array}$ & Insecticide & 687.3 & 0.006 & & & \\
\hline CLOTHIANIDIN & Insecticide & 686.8 & 0.006 & & & \\
\hline IMIDACLOPRID & Insecticide & 647.1 & 0.005 & 978 & 0.01 & 9.5 \\
\hline DESMEDIPHAM & Herbicide & 645.2 & 0.005 & 1348.5 & 0.01 & 2334.8 \\
\hline METIRAM & Fungicide & 619.2 & 0.005 & 2068.8 & 0.02 & 14862.4 \\
\hline ASPHALT SOLIDS & Fungicide & 614.7 & 0.005 & 591.9 & 0.01 & 1387.5 \\
\hline STRYCHNINE & Rodenticide & 595.5 & 0.005 & 244.8 & 0 & 163.2 \\
\hline DICHLOBENIL & Herbicide & 572.3 & 0.005 & 684.7 & 0.01 & 728.2 \\
\hline ALUMINUM PHOSPHIDE & Insecticide & 569.3 & 0.005 & 269.6 & 0 & 2215.7 \\
\hline LIME SULPHUR & Fungicide & 564.6 & 0.005 & 364.8 & 0 & 224 \\
\hline $\begin{array}{l}\text { PROPAMOCARB } \\
\text { HYDROCHLORIDE }\end{array}$ & Fungicide & 540.1 & 0.004 & 411.9 & 0 & 1271.3 \\
\hline DELTAMETHRIN & Insecticide & 537.6 & 0.004 & 2735.1 & 0.03 & 775.1 \\
\hline SURFACTANT MIXTURE & Adjuvant & 533.8 & 0.004 & & & \\
\hline PARADICHLOROBENZENE & Insecticide & 508.5 & 0.004 & 13.9 & 0 & 65.3 \\
\hline PROPYZAMIDE & Herbicide & 475.7 & 0.004 & 179.4 & 0 & 272 \\
\hline FOSETYL-AL & Fungicide & 466.5 & 0.004 & 351.8 & 0 & 166.3 \\
\hline FORMALDEHYDE & Fungicide & 464.0 & 0.004 & 17.8 & 0 & 96.2 \\
\hline PHENMEDIPHAM & Herbicide & 434.1 & 0.003 & 1348.5 & 0.01 & 2330.3 \\
\hline CAPTAN & Insecticide & 429.8 & 0.003 & 439.4 & 0 & 286.8 \\
\hline ACETAMIPRID & Insecticide & 414.6 & 0.003 & & & \\
\hline THIABENDAZOLE & Fungicide & 412.5 & 0.003 & 1388.8 & 0.01 & 3187.2 \\
\hline COPPER NAPHTHENATE & $\begin{array}{l}\text { Anti- } \\
\text { microbial }\end{array}$ & 404.6 & 0.003 & 59.8 & 0 & 123.2 \\
\hline $\mathrm{MCPB}$ & Herbicide & 396.0 & 0.003 & 1717.5 & 0.02 & 3271.5 \\
\hline DAZOMET & $\begin{array}{l}\text { Soil } \\
\text { fumigant }\end{array}$ & 392.0 & 0.003 & 78.4 & 0 & 627.2 \\
\hline ACEPHATE & Insecticide & 376.9 & 0.003 & 383.6 & 0 & 257.6 \\
\hline TRIBASIC COPPER SULPHATE & Fungicide & 375.9 & 0.003 & 130.9 & 0 & 159.6 \\
\hline CYFLUTHRIN & Insecticide & 351.6 & 0.003 & 92.3 & 0 & 1.3 \\
\hline PYRIDABEN & Insecticide & 350.6 & 0.003 & 23.5 & 0 & 17.1 \\
\hline DRIED BLOOD & Vertebrate & 327.0 & 0.003 & & & \\
\hline ENDOSULFAN & Insecticide & 294.9 & 0.002 & 5229.7 & 0.05 & 761.1 \\
\hline BORAX & Insecticide & 291.8 & 0.002 & 168.2 & 0 & 218.8 \\
\hline $\begin{array}{l}\text { SODIUM ALPHA-OLEFIN } \\
\text { SULFONATE }\end{array}$ & Adjuvant & 291.0 & 0.002 & 299.1 & 0 & \\
\hline
\end{tabular}




\begin{tabular}{|c|c|c|c|c|c|c|}
\hline $\begin{array}{l}\text { ACTIVE INGREDIENT } \\
\text { NAME }\end{array}$ & Type of use & $\begin{array}{l}2008 \text { total } \\
\text { (kg ai) }\end{array}$ & $\begin{array}{c}2008 \\
\%\end{array}$ & $\begin{array}{l}2003 \text { total } \\
\text { (kg ai) }\end{array}$ & $\begin{array}{c}2003 \\
\%\end{array}$ & $\begin{array}{l}1998 \text { total } \\
\text { (kg ai) }\end{array}$ \\
\hline METSULFURON-METHYL & Herbicide & 286.3 & 0.002 & 360.9 & 0 & 938.6 \\
\hline BRONOPOL & Preservative & 276.4 & 0.002 & 192.1 & 0 & \\
\hline CARBOFURAN & Insecticide & 265.0 & 0.002 & 676.1 & 0.01 & 6413.4 \\
\hline DICHLORVOS & Insecticide & 254.6 & 0.002 & 193.5 & 0 & 335.2 \\
\hline PYRETHRINS & Insecticide & 240.0 & 0.002 & 220.9 & 0 & 178.2 \\
\hline ETHAMETSULFURON-METHYL & Herbicide & 238.0 & 0.002 & 844.4 & 0.01 & 4636.4 \\
\hline METHAMIDOPHOS & Insecticide & 230.4 & 0.002 & 1008.0 & 0.01 & 19.2 \\
\hline CHLORSULFURON & Herbicide & 225.8 & 0.002 & 98.6 & 0 & 66.7 \\
\hline OXYCARBOXIN & Fungicide & 216.5 & 0.002 & 185.3 & 0 & 154.1 \\
\hline QUINCLORAC & Herbicide & 213.2 & 0.002 & 878.1 & 0.01 & 1459.4 \\
\hline NAPROPAMIDE & Herbicide & 211.9 & 0.002 & 159.1 & 0 & 294.6 \\
\hline RIMSULFURON & Herbicide & 208.4 & 0.002 & 219.1 & 0 & 63.2 \\
\hline SOAP (HERBICIDAL) & Herbicide & 188.4 & 0.002 & 42.4 & 0 & 1221.5 \\
\hline $\begin{array}{l}\text { BACILLUS THURINGIENSIS SSP } \\
\text { KURSTAKI }\end{array}$ & Insecticide & 184.5 & 0.001 & 35.8 & 0 & $28273.5^{*}$ \\
\hline METHOPRENE & Insecticide & 174.1 & 0.001 & 6.7 & 0 & \\
\hline $\begin{array}{l}\text { N-OCTYL BICYCLOHEPTENE } \\
\text { DICARBOXIMIDE }\end{array}$ & Insecticide & 154.8 & 0.001 & 33.4 & 0 & 144.5 \\
\hline ZINC NAPHTHENATE & $\begin{array}{l}\text { Anti- } \\
\text { microbial }\end{array}$ & 153.5 & 0.001 & 23.6 & 0 & 40 \\
\hline BACILLUS SPHAERICUS & Insecticide & 152.4 & 0.001 & & & \\
\hline $\begin{array}{l}\text { N-ALKYL DIMETHYL BENZYL } \\
\text { AMMONIUM CHLORIDE }\end{array}$ & Disinfectant & 148.0 & 0.001 & 163.4 & 0 & 63.7 \\
\hline $\begin{array}{l}\text { DI-N-PROPYL } \\
\text { ISOCINCHOMERONATE }\end{array}$ & Insecticide & 144.9 & 0.001 & 5.8 & 0 & 6.4 \\
\hline COPPER OXYCHLORIDE & Fungicide & 144.7 & 0.001 & 649.5 & 0.01 & 220.2 \\
\hline BORACIC ACID & Insecticide & 135.8 & 0.001 & 41.6 & 0 & 322.7 \\
\hline RESMETHRIN & Insecticide & 134.0 & 0.001 & 17.5 & 0 & 2.4 \\
\hline NICOSULFURON & Herbicide & 126.7 & 0.001 & 140.1 & 0 & \\
\hline $\begin{array}{l}\text { DIDECYL DIMETHYL } \\
\text { AMMONIUM CHLORIDE }\end{array}$ & $\begin{array}{l}\text { Anti- } \\
\text { microbial }\end{array}$ & 106.5 & 0.001 & 167.4 & 0 & 120.6 \\
\hline METALDEHYDE & Insecticide & 105.5 & 0.001 & 101.3 & 0 & 476.5 \\
\hline OXYFLUORFEN & Herbicide & 89.0 & 0.001 & 46 & 0 & 27.4 \\
\hline FERBAM & Herbicide & 80.1 & 0.001 & 95.1 & 0 & 77.6 \\
\hline TRINEXAPAC-ETHYL & $\begin{array}{l}\text { Growth } \\
\text { Regulator }\end{array}$ & 77.7 & 0.001 & 44.8 & 0 & \\
\hline TRIFLUSULFURON METHYL & Herbicide & 75.1 & 0.001 & 81.8 & 0 & \\
\hline PYRAZON & Herbicide & 72.2 & 0.001 & 338 & 0 & 1204.9 \\
\hline AZINPHOS-METHYL & Insecticide & 69.2 & 0.001 & 304 & 0 & 260.6 \\
\hline $\begin{array}{l}\text { BACILLUS THURINGIENSIS SSP } \\
\text { ISRAELENSIS }\end{array}$ & Insecticide & 62.2 & 0 & 34.4 & 0 & $11079.8^{*}$ \\
\hline DAMINOZIDE & $\begin{array}{l}\text { Growth } \\
\text { Regulator }\end{array}$ & 57.8 & 0 & 119.9 & 0 & 147.5 \\
\hline
\end{tabular}




\begin{tabular}{|c|c|c|c|c|c|c|}
\hline $\begin{array}{l}\text { ACTIVE INGREDIENT } \\
\text { NAME }\end{array}$ & Type of use & $\begin{array}{l}2008 \text { total } \\
\text { (kg ai) }\end{array}$ & $\begin{array}{c}2008 \\
\%\end{array}$ & $\begin{array}{l}2003 \text { total } \\
\text { (kg ai) }\end{array}$ & $\begin{array}{c}2003 \\
\%\end{array}$ & $\begin{array}{l}1998 \text { total } \\
\text { (kg ai) }\end{array}$ \\
\hline PYMETROZINE & Insecticide & 55.5 & 0 & 95 & 0 & \\
\hline ETRIDIAZOLE & Herbicide & 54.9 & 0 & 122.1 & 0 & 210.6 \\
\hline METHOMYL & Insecticide & 54.8 & 0 & 436.8 & 0 & 434.5 \\
\hline CHLORMEQUAT & $\begin{array}{l}\text { Growth } \\
\text { Regulator }\end{array}$ & 54.3 & 0 & 89.7 & 0 & 62.3 \\
\hline ZINEB & Fungicide & 51.5 & 0 & 99.5 & 0 & 491.7 \\
\hline ROTENONE & Herbicide & 49.7 & 0 & 61.7 & 0 & 180 \\
\hline TRIASULFURON & Herbicide & 45.5 & 0 & 190.3 & 0 & 505 \\
\hline PROPOXUR & Insecticide & 41.3 & 0 & 107.2 & 0 & 170 \\
\hline FATTY ACID & $\begin{array}{l}\text { Growth } \\
\text { Regulator }\end{array}$ & 36.9 & 0 & 88.9 & 0 & 34.6 \\
\hline NICOTINE & Insecticide & 36.4 & 0 & 27.2 & 0 & 27.5 \\
\hline FOLPET & Insecticide & 35.9 & 0 & 55.4 & 0 & 54.8 \\
\hline WATER SOLUBLE DYES & Herbicide & 35.1 & 0 & 48.7 & 0 & 5.1 \\
\hline NATURAL GUM RESINS & Insecticide & 32.3 & 0 & 0.67 & 0 & 9 \\
\hline PROPANIL & Herbicide & 32.0 & 0 & 96 & 0 & 1616 \\
\hline CYPERMETHRIN & Insecticide & 30.9 & 0 & 26.1 & 0 & 439.6 \\
\hline $\begin{array}{l}\text { SILICON DIOXIDE FRESH } \\
\text { WATER FOSSILS }\end{array}$ & Insecticide & 29.0 & 0 & & & \\
\hline FERRIC PHOSPHATE & Insecticide & 28.8 & 0 & 11.3 & 0 & \\
\hline FERIC SODIUM EDTA & Insecticide & 28.1 & 0 & & & \\
\hline OIL OF BLACK PEPPER & Vertebrate & 27.7 & 0 & 16.5 & 0 & 12 \\
\hline OXADIAZON & Herbicide & 27.2 & 0 & 19.9 & 0 & 41.2 \\
\hline DICOFOL & Insecticide & 27.0 & 0 & 84 & 0 & 423.6 \\
\hline ZINC PHOSPHIDE & Rodenticide & 26.3 & 0 & 435.3 & 0 & 49.2 \\
\hline D-TRANS ALLETHRIN & Insecticide & 25.2 & 0 & 320.6 & 0 & 20.7 \\
\hline METHYL NONYL KETONE & Vertebrate & 24.1 & 0 & 27.5 & 0 & 50 \\
\hline COPPER SULPHATE & Fungicide & 23.7 & 0 & 672.1 & 0.01 & 316.1 \\
\hline CHLORPHACINONE & Rodenticide & 23.7 & 0 & 1.7 & 0 & 1.8 \\
\hline PHOSALONE & Insecticide & 21.4 & 0 & 23.5 & 0 & 5.6 \\
\hline $\begin{array}{l}\text { POTASSIUM } \\
\text { MONOPERSULPHATE }\end{array}$ & Disinfectant & 20.3 & 0 & 59.9 & 0 & 15 \\
\hline CHLORPROPHAM & Herbicide & 20.2 & 0 & 120.4 & 0 & 679.8 \\
\hline PROPETAMPHOS & Insecticide & 18.9 & 0 & 0.29 & 0 & \\
\hline SPINOSAD FACTOR A PLUS & Insecticide & 18.7 & 0 & 1.9 & 0 & \\
\hline TETRAMETHRIN & Insecticide & 18.4 & 0 & 20.3 & 0 & 14.2 \\
\hline BACILLUS SUBTILUS & Insecticide & 17.7 & 0 & & & \\
\hline OXINE BENZOATE & Fungicide & 17.0 & 0 & 52.5 & 0 & 59.1 \\
\hline MYCLOBUTANIL & Fungicide & 16.7 & 0 & 162.6 & 0 & 16.8 \\
\hline TEBUFENOZIDE & Insecticide & 15.4 & 0 & 8.6 & 0 & \\
\hline D-CIS. TRANS ALLETHRIN & Insecticide & 15.1 & 0 & 5.7 & 0 & 1.7 \\
\hline D-PHENOTHRIN & Insecticide & 14.8 & 0 & 6.8 & 0 & \\
\hline
\end{tabular}




\begin{tabular}{|c|c|c|c|c|c|c|}
\hline $\begin{array}{l}\text { ACTIVE INGREDIENT } \\
\text { NAME }\end{array}$ & Type of use & $\begin{array}{l}2008 \text { total } \\
\text { (kg ai) }\end{array}$ & $\begin{array}{c}2008 \\
\%\end{array}$ & $\begin{array}{l}2003 \text { total } \\
\text { (kg ai) }\end{array}$ & $\begin{array}{c}2003 \\
\%\end{array}$ & $\begin{array}{l}1998 \text { total } \\
\text { (kg ai) }\end{array}$ \\
\hline FENHEXAMID & Fungicide & 14.3 & 0 & 2.5 & 0 & \\
\hline BIFENAZATE & Insecticide & 12.6 & 0 & & & \\
\hline $\begin{array}{l}\text { PUTRESCENT WHOLE EGG } \\
\text { SOLIDS }\end{array}$ & Vertebrate & 11.3 & 0 & & & \\
\hline SPIROTETRAMAT & Insecticide & 10.3 & 0 & & & \\
\hline MESOTRIONE & Fungicide & 9.2 & 0 & & & \\
\hline FENBUTATIN OXIDE & Insecticide & 8.6 & 0 & 22.1 & 0 & 12.4 \\
\hline BROMADIOLONE & Rodenticide & 5.9 & 0 & 1.2 & 0 & 1.2 \\
\hline DICLOFOP-METHYL & Herbicide & 5.7 & 0 & 715.2 & 0.01 & 3239.9 \\
\hline PHOSMET & Insecticide & 5.6 & 0 & 140.7 & 0 & 370 \\
\hline SULFOSULFURON & Herbicide & 5.2 & 0 & 596.3 & 0.01 & \\
\hline FENAMIDONE & Fungicide & 5.0 & 0 & & & \\
\hline WARFARIN & Rodenticide & 3.8 & 0 & 2 & 0 & 1.8 \\
\hline $\begin{array}{l}\text { GLIOCLADIUM } \\
\text { CATENULATUM } \\
\end{array}$ & Fungicide & 3.6 & 0 & & & \\
\hline DODEMORPH-ACETATE & Fungicide & 3.6 & 0 & 42.8 & 0 & 55.2 \\
\hline ACEQUINOCYL & Insecticide & 3.5 & 0 & & & \\
\hline PACLOBUTRAZOL & $\begin{array}{l}\text { Growth } \\
\text { Regulator }\end{array}$ & 3.0 & 0 & 0.23 & 0 & \\
\hline ABAMECTIN & Insecticide & 2.9 & 0 & 6.7 & 0 & 3.6 \\
\hline CYROMAZINE & Insecticide & 2.7 & 0 & 9.8 & 0 & \\
\hline KINOPRENE & Insecticide & 2.5 & 0 & 9.9 & 0 & 33.6 \\
\hline OXAMYL & Insecticide & 2.4 & 0 & 2.4 & 0 & 9.6 \\
\hline BRODIFACOUM & Rodenticide & 2.3 & 0 & 0.08 & 0 & 0.1 \\
\hline AMMONIA & Rodenticide & 2.3 & 0 & 0.43 & 0 & 1.1 \\
\hline DIFLUBENZURON & Insecticide & 2.3 & 0 & 2.6 & 0 & \\
\hline DIMETHOMORPH & Fungicide & 1.8 & 0 & 9.9 & 0 & 72.9 \\
\hline SPIROMESIFEN & Insecticide & 1.7 & 0 & & & \\
\hline 1-OCTEN-3-OL & Insecticide & 1.6 & 0 & & & \\
\hline ISOXABEN & Herbicide & 1.4 & 0 & & & \\
\hline P-MENTHANE-3, 8-DIOL & Insecticide & 1.3 & 0 & 22.7 & 0 & \\
\hline PIPERINE & Rodenticide & 1.0 & 0 & 0.62 & 0 & 0.4 \\
\hline PYRIPROXYFEN & Insecticide & 0.9 & 0 & & & \\
\hline CYPRODINIL & Fungicide & 0.9 & 0 & & & \\
\hline DIPHACINONE & Rodenticide & 0.9 & 0 & 0.37 & 0 & 0.4 \\
\hline HYDRAMETHYLNON & Insecticide & 0.9 & 0 & 20.4 & 0 & 9.2 \\
\hline FENTHION & Insecticide & 0.8 & 0 & 418.8 & 0 & 293.6 \\
\hline QUIZALOFOP-ETHYL & Herbicide & 0.8 & 0 & 44.7 & 0 & 23101.0 \\
\hline BISPYRIBAC & Herbicide & 0.5 & 0 & & & \\
\hline DENATONIUM BENZOATE & Vertebrate & 0.5 & 0 & & & \\
\hline 4-AMINOPYRIDINE & Rodenticide & 0.4 & 0 & 0.21 & 0 & 1.5 \\
\hline $\begin{array}{l}\text { ARTIFICIAL ESSENTIAL OIL } \\
\text { BLEND }\end{array}$ & Insecticide & 0.4 & 0 & & & \\
\hline
\end{tabular}




\begin{tabular}{|c|c|c|c|c|c|c|}
\hline $\begin{array}{l}\text { ACTIVE INGREDIENT } \\
\text { NAME }\end{array}$ & Type of use & $\begin{array}{l}2008 \text { total } \\
\text { (kg ai) }\end{array}$ & $\begin{array}{c}2008 \\
\%\end{array}$ & $\begin{array}{l}2003 \text { total } \\
\text { (kg ai) }\end{array}$ & $\begin{array}{c}2003 \\
\%\end{array}$ & $\begin{array}{l}1998 \text { total } \\
\text { (kg ai) }\end{array}$ \\
\hline SULFAQUINOXALINE & Rodenticide & 0.4 & 0 & 0.41 & 0 & 1.4 \\
\hline DIFETHIALONE & Rodenticide & 0.2 & 0 & 0.06 & 0 & \\
\hline SPINETORAM & Insecticide & 0.2 & 0 & & & \\
\hline BROMETHALIN & Rodenticide & 0.2 & 0 & & & \\
\hline BENDIOCARB & Insecticide & 0.2 & 0 & 36 & 0 & 59.3 \\
\hline CAPSAICIN & Vertebrate & 0.2 & 0 & 0.1 & 0 & 0.1 \\
\hline ANCYMIDOL & $\begin{array}{l}\text { Growth } \\
\text { Regulator }\end{array}$ & 0.03 & 0 & 0.03 & 0 & 0.1 \\
\hline 4-CPA & $\begin{array}{l}\text { Growth } \\
\text { Regulator }\end{array}$ & 0.03 & 0 & & & \\
\hline D-CIS ALLETHRIN & Insecticide & 0.03 & 0 & & & \\
\hline UNICONAZOLE-P & $\begin{array}{l}\text { Growth } \\
\text { Regulator }\end{array}$ & 0.02 & 0 & & & \\
\hline STREPTOMYCES LYDICUS & Fungicide & 0.02 & 0 & & & \\
\hline STREPTOMYCES GRISEOVIRIDIS & Fungicide & 0.008 & 0 & 0.04 & 0 & \\
\hline $\begin{array}{l}\text { GERMAN COCKROACH } \\
\text { EXTRACT }\end{array}$ & Insecticide & 0.006 & 0 & & & \\
\hline GIBBERELLIC ACID & $\begin{array}{l}\text { Growth } \\
\text { Regulator }\end{array}$ & 0.004 & 0 & 0.06 & 0 & 0.6 \\
\hline CHOLECALCIFEROL & Rodenticide & 0.003 & 0 & 0.012 & 0 & 0.1 \\
\hline AMMONIUM SULPHATE & Herbicide & & & 51595.1 & 0.56 & 71104.4 \\
\hline LINDANE & Insecticide & & & 4779.5 & 0.05 & 56743.7 \\
\hline BENOMYL & Fungicide & & & 3275.0 & 0.04 & 14616.3 \\
\hline TRICHLORFON & Insecticide & & & 2331.3 & 0.03 & 34334.3 \\
\hline HYDROGEN PEROXIDE & Insecticide & & & 996.8 & 0.01 & \\
\hline $\begin{array}{l}\text { MUSTARD SEED POWDER } \\
\text { (BRASSICA HIRTA) }\end{array}$ & Rodenticide & & & 471.3 & 0.01 & \\
\hline CYCLOATE & Herbicide & & & 460.8 & 0 & 2289.6 \\
\hline METAM & $\begin{array}{l}\text { Soil } \\
\text { fumigant }\end{array}$ & & & 415.1 & 0 & 410.7 \\
\hline CHLORONEB & Fungicide & & & 233.9 & 0 & 559.3 \\
\hline PROPYZAMIDE & Herbicide & & & 179.4 & 0 & 272 \\
\hline TALL OIL FATTY ACIDS & Adjuvant & & & 176 & 0 & 1470.4 \\
\hline PIRIMICARB & Insecticide & & & 162.2 & 0 & 154.1 \\
\hline $\begin{array}{l}\text { TALLOW FATTY ACID AMINE } \\
\text { ETHOXYLATE }\end{array}$ & Adjuvant & & & 138.1 & 0 & 3272.2 \\
\hline TRIADIMENOL & Fungicide & & & 120.1 & 0 & 178 \\
\hline $\begin{array}{l}\text { SODIUM METABORATE } \\
\text { TETRAHYDRATE }\end{array}$ & Herbicide & & & 117.5 & 0 & 1616.3 \\
\hline BENSULIDE & Herbicide & & & 95.9 & 0 & 212.6 \\
\hline PARAFORMALDEHYDE & Disinfectant & & & 68.3 & 0 & \\
\hline CYMOXANIL & Fungicide & & & 65.9 & 0 & \\
\hline $\begin{array}{l}\text { OCTYLPHENOXYPOLYETHOXY } \\
\text { ETHANOL PHOSPHATE ESTER }\end{array}$ & Adjuvant & & & 60.5 & 0 & \\
\hline
\end{tabular}




\begin{tabular}{|c|c|c|c|c|c|c|}
\hline $\begin{array}{l}\text { ACTIVE INGREDIENT } \\
\text { NAME }\end{array}$ & Type of use & $\begin{array}{l}2008 \text { total } \\
\text { (kg ai) }\end{array}$ & $\begin{array}{c}2008 \\
\%\end{array}$ & $\begin{array}{l}2003 \text { total } \\
\text { (kg ai) }\end{array}$ & $\begin{array}{c}2003 \\
\%\end{array}$ & $\begin{array}{l}1998 \text { total } \\
\text { (kg ai) }\end{array}$ \\
\hline CREOSOTE & $\begin{array}{l}\text { Anti- } \\
\text { microbial }\end{array}$ & & & 58.1 & 0 & 805.2 \\
\hline SODIUM CHLORATE & Herbicide & & & 53 & 0 & 729.1 \\
\hline CYANAZINE & Herbicide & & & 45 & 0 & 3891.6 \\
\hline ENDOTHALL & Herbicide & & & 44.3 & 0 & 511 \\
\hline $\begin{array}{l}\text { N-ALKYL } \\
\text { POLYETHOXYETHANOL }\end{array}$ & Adjuvant & & & 32.5 & 0 & 52.5 \\
\hline METHOXYCHLOR & Insecticide & & & 24.7 & 0 & 109.9 \\
\hline $\begin{array}{l}\text { 1-BROMO-3-CHLORO-5,5- } \\
\text { DIMETHYLHYDANTOIN }\end{array}$ & $\begin{array}{l}\text { Anti- } \\
\text { microbial }\end{array}$ & & & 22.4 & 0 & 20.5 \\
\hline TRIFORINE & Fungicide & & & 22 & 0 & 20.6 \\
\hline POLYMERIZED BUTENES & Vertebrate & & & 21.7 & 0 & 92.9 \\
\hline N-ALKYL DIETHANOLAMINE & Adjuvant & & & 20.8 & 0 & 33.6 \\
\hline 1,2-ETHANEDIOL & Adjuvant & & & 17.4 & 0 & 87 \\
\hline PYRIDATE & Herbicide & & & 12.6 & 0 & 486 \\
\hline METHIOCARB & Insecticide & & & 12.1 & 0 & \\
\hline METOLACHLOR & Herbicide & & & 11.2 & 0 & 4297.9 \\
\hline COUMAPHOS & Insecticide & & & 7.3 & 0 & 45.6 \\
\hline $\begin{array}{l}10,10^{\prime}- \\
\text { OXYBIS(PHENOXARSINE) }\end{array}$ & Preservative & & & 5.3 & 0 & \\
\hline ETHION & Insecticide & & & 4.6 & 0 & 26.9 \\
\hline METHYL ANTHRANILATE & Vertebrate & & & 4.1 & 0 & \\
\hline FENVALERATE & Fungicide & & & 3.8 & 0 & 4.1 \\
\hline ALLETHRIN & Insecticide & & & 2.8 & 0 & 2 \\
\hline FENHEXAMID & Fungicide & & & 2.5 & 0 & \\
\hline STREPTOMYCIN & Fungicide & & & 1 & 0 & 2.1 \\
\hline FLAMPROP-M-METHYL & Herbicide & & & 0.08 & 0 & 1091.5 \\
\hline DITHIOPYR & Herbicide & & & 0.05 & 0 & 2.1 \\
\hline 6-BENZYLAMINOPURINE & $\begin{array}{l}\text { Growth } \\
\text { Regulator }\end{array}$ & & & 0.04 & 0 & \\
\hline FENOXAPROP-ETHYL & Herbicide & & & 0.012 & 0 & 117.9 \\
\hline ERGOCALCIFEROL & Rodenticide & & & 0.002 & 0 & 0.02 \\
\hline TOTAL & & 12476095.8 & 100 & 9264487.7 & 100 & 9300497.8 \\
\hline
\end{tabular}

Note: Bacillus thuringiensis active ingredient calculations in 1998 assumed that formulation consisted of $100 \%$ active ingredient, as guarantees on a percentage basis were not available. Guarantees on a percentage basis were obtained for these products in 2003. Recalculating the 1998 figures resulted in total active ingredient sold for Bt kurstaki and Bt israelensis of 617.994 and $1.654 \mathrm{~kg}$ ai, respectively. 


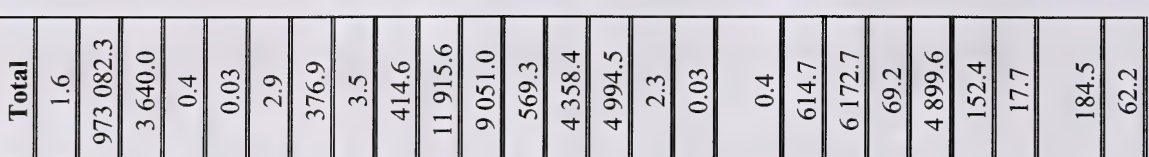

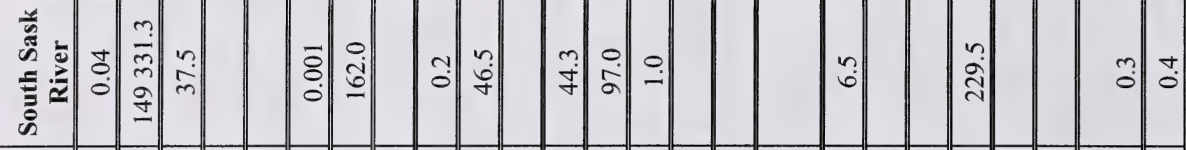

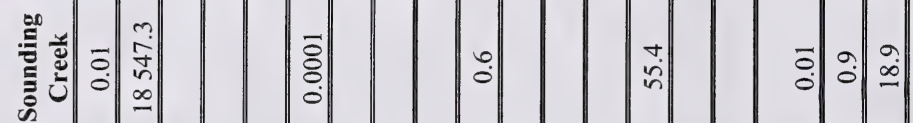

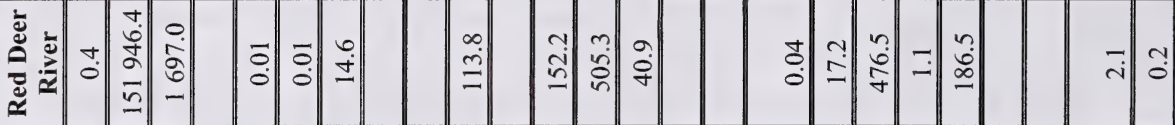

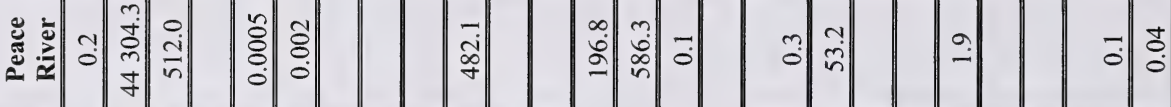

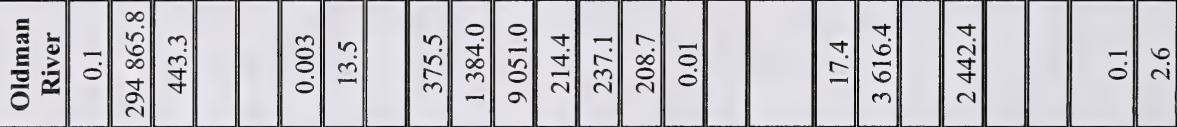

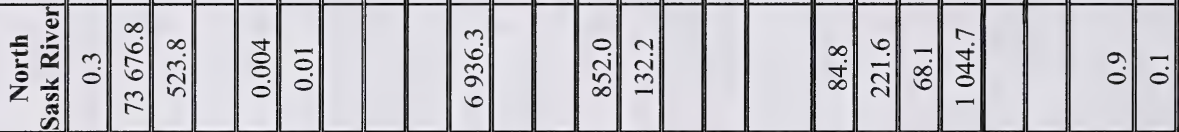

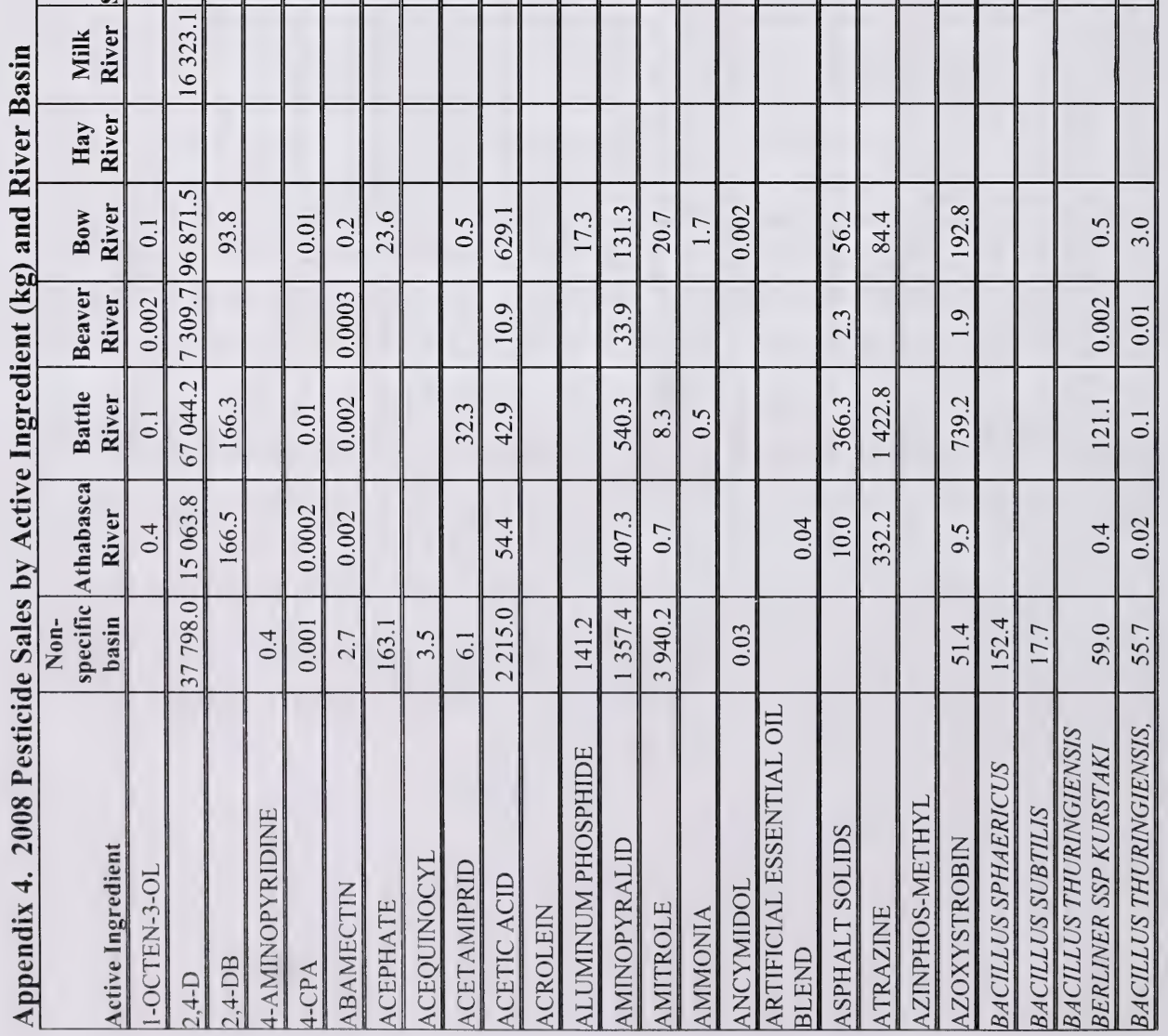




\begin{tabular}{|c|c|c|c|c|c|c|c|c|c|c|c|c|c|c|c|c|c|c|c|c|c|c|c|c|c|c|}
\hline 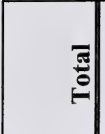 & & $\stackrel{\sim}{0}$ & 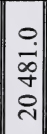 & $\begin{array}{l}0 \\
\stackrel{0}{\simeq}\end{array}$ & $\tilde{0}$ & \begin{tabular}{l|}
$\infty$ \\
$\dot{n}$ \\
2
\end{tabular} & ते & 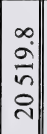 & ri & \begin{tabular}{l||}
9 \\
0 \\
0 \\
$\vdots$ \\
$\sim$
\end{tabular} & iे & רִ. & $\begin{array}{l}-1 \\
\vdots \\
\vdots \\
0 \\
m\end{array}$ & 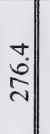 & $\begin{array}{l}\frac{6}{4} \\
\frac{1}{7} \\
\end{array}$ & ํ. & 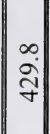 & $\begin{array}{l}m \\
2 \\
\infty \\
a \\
0\end{array}$ & $\begin{array}{l}= \\
2 \\
\simeq \\
-2\end{array}$ & $\begin{array}{l}0 \\
0 \\
0 \\
0\end{array}$ & 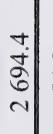 & $\stackrel{m}{n}$ & 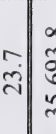 & 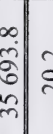 & $\mid \begin{array}{l}\tilde{N} \\
\infty \\
\tilde{z} \\
\alpha\end{array}$ & : \\
\hline 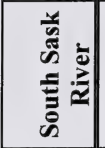 & & & $\begin{array}{l}\vec{n} \\
\stackrel{\infty}{n} \\
+\end{array}$ & & & $\grave{o}$ & $\stackrel{?}{0}$ & $\begin{array}{c}0 \\
\vec{T} \\
\dot{d} \\
m\end{array}$ & $\overrightarrow{0}$ & $\mid$ & o. & $\begin{array}{l}\text { t. } \\
\vdots \\
0\end{array}$ & $\begin{array}{l}n \\
\\
\sigma \\
\delta \\
0\end{array}$ & $\stackrel{.}{\infty}$ & ๙ે. & $\begin{array}{l}\overline{0} \\
0\end{array}$ & is & $\begin{array}{c}n \\
\infty \\
\infty\end{array}$ & $\begin{array}{l}r \\
\dot{0} \\
\dot{v} \\
-\end{array}$ & $\begin{array}{c}\dot{t} \\
\dot{b} \\
\grave{c}\end{array}$ & in & & \begin{tabular}{l|l} 
\\
0 \\
0
\end{tabular} & 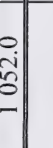 & ֶे & \\
\hline | & & & 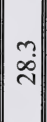 & & & & ऽ̋. & & $\begin{array}{l}\tilde{0} \\
0 \\
0\end{array}$ & $\begin{array}{l}\sim \\
\infty \\
\infty\end{array}$ & $\overrightarrow{0}$ & & $\begin{array}{l}0 \\
\bar{n} \\
=\end{array}$ & & $\begin{array}{l}\circ \\
\stackrel{0}{0}\end{array}$ & & & ते & $\begin{array}{c}0 \\
\text { in } \\
\end{array}$ & & $\hat{-}$ & & & & 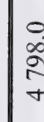 & \\
\hline 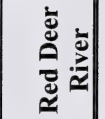 & & & $\begin{array}{l}\mathrm{v} \\
\dot{ \pm} \\
\mathrm{v}\end{array}$ & & & $\stackrel{m}{\sim}$ & $\frac{m}{m}$ & \begin{tabular}{l|l}
0 \\
$\vdots$ \\
$\cdots$
\end{tabular} & ثे. & 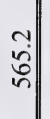 & oे & ชి & 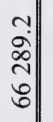 & તิ & $\begin{array}{l}\infty \\
\infty \\
0 \\
\\
\end{array}$ & $\begin{array}{l}\tau \\
0 \\
0\end{array}$ & 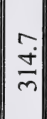 & के & 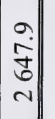 & r & त्. & & ¿.|. & & 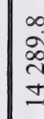 & \\
\hline لَّ & & & 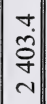 & & & $\stackrel{\infty}{-}$ & $\tilde{n}$ & 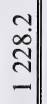 & ชุ & 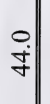 & ?? & $\begin{array}{l}\overline{0} \\
0\end{array}$ & ㄹ. & $\underline{n}$ & $\begin{array}{c}\stackrel{t}{i} \\
\stackrel{J}{6}\end{array}$ & - & $\dot{0}$ & ज. & - & $\stackrel{n}{=}$ & ণ্் & & & & & 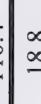 \\
\hline 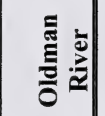 & & & 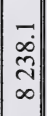 & & & 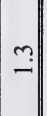 & $\begin{array}{l}n \\
\infty \\
-\end{array}$ & $\begin{array}{l}\text { d } \\
\text { cे } \\
\text { in }\end{array}$ & 3 & 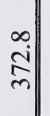 & $\stackrel{\circ}{\circ}$ & $\overrightarrow{0}$ & \begin{tabular}{l||}
0 \\
\\
$\hat{\alpha}$ \\
$\hat{\sigma}$
\end{tabular} & 2 & $\begin{array}{l}\infty \\
\stackrel{i}{\mathrm{i}}\end{array}$ & $\overline{0}$ & $\stackrel{m}{n}$ & 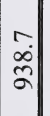 & $\begin{array}{c}r \\
o \\
o \\
o \\
m\end{array}$ & $\begin{array}{l}0 \\
\text { ì }\end{array}$ & 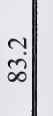 & & & 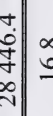 & 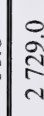 & \\
\hline 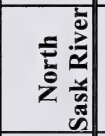 & & & $\begin{array}{l}m \\
\vdots \\
0 \\
0 \\
0\end{array}$ & & & तi & \begin{tabular}{l||}
$\overrightarrow{0}$ \\
$\infty$
\end{tabular} & \begin{tabular}{l||}
0 \\
0 \\
0 \\
$=$ \\
$=$
\end{tabular} & $\begin{array}{l}0 \\
0\end{array}$ & $\begin{array}{c}n \\
⿱ ⺌ \\
\infty\end{array}$ & $\stackrel{m}{-}$ & $\begin{array}{l}\text { J } \\
0\end{array}$ & 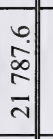 & ثิ) & $\frac{0}{0}$ & $\begin{array}{l}n \\
\tilde{o} \\
0\end{array}$ & $\stackrel{i}{-}$ & $\begin{array}{l}0 \\
\dot{j} \\
\stackrel{2}{2}\end{array}$ & $\begin{array}{l}0 \\
\text { in } \\
-\end{array}$ & & تٕ: & & & & $\begin{array}{l}0 \\
\infty \\
0 \\
0\end{array}$ & 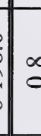 \\
\hline 总总 & & & & & & & $\tilde{O}$ & & & ? & & & $\begin{array}{l}\overrightarrow{0} \\
\tilde{y} \\
\tilde{\sigma} \\
0\end{array}$ & & & & & & $\begin{array}{l}0 \\
\text { î } \\
\text { m. }\end{array}$ & & & & & & & \\
\hline 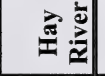 & & & & & & & $0^{\circ}$ & & & & & & & & & & & & & & & & & & & \\
\hline 空 & & & $\begin{array}{l}\infty \\
+ \\
\mathbb{b}\end{array}$ & & & ô & $\frac{m}{\infty}$ & \begin{tabular}{c}
0 \\
\multirow{2}{0}{} \\
-1
\end{tabular} & $\stackrel{+}{0}$ & $\begin{array}{l}+ \\
\check{n} \\
\end{array}$ & $\exists$ & $\overline{0}$ & \begin{tabular}{l|l|}
$n$ \\
0 \\
0 \\
$m$ \\
$m$
\end{tabular} & 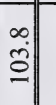 & $\begin{array}{l}0 \\
0 \\
0 \\
0\end{array}$ & $\overrightarrow{0}$ & $\begin{array}{l}n \\
\infty \\
\sim \\
\sim\end{array}$ & $\begin{array}{l}0 \\
\dot{0} \\
\stackrel{-}{-}\end{array}$ & $\begin{array}{l}n \\
\infty \\
\infty \\
-\end{array}$ & $\stackrel{\infty}{\sim}$ & 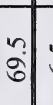 & "ֶ. & & \begin{tabular}{l|l}
$n$ & \\
$\infty$ & \\
0 & \\
$N$ & \\
$N$ &
\end{tabular} & 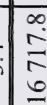 & \\
\hline 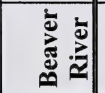 & & & & & & $?$ & $\stackrel{+}{\sim}$ & 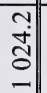 & $\begin{array}{l}0 \\
\delta \\
0\end{array}$ & in & $\overline{0}$ & & 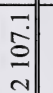 & & \begin{tabular}{l}
$\infty$ \\
\hdashline \\
0
\end{tabular} & $\begin{array}{l}0 \\
\delta \\
0\end{array}$ & $\stackrel{0}{0}$ & $\begin{array}{l}\infty \\
2 \\
2\end{array}$ & \begin{tabular}{l|}
$\infty$ \\
\\
\end{tabular} & & 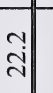 & & & $\begin{array}{l}0 \\
: \\
0\end{array}$ & $\stackrel{\vec{\infty}}{\sim}$ & \\
\hline 竎 & & & $\begin{array}{l}0 \\
\dot{\infty} \\
\infty\end{array}$ & & & $\begin{array}{l}\infty \\
\dot{r}\end{array}$ & \begin{tabular}{l||}
- \\
$\infty$ \\
$m$
\end{tabular} & $\begin{array}{c}\dot{y} \\
\dot{0} \\
\dot{\alpha} \\
m\end{array}$ & ๙̃ & î & $\stackrel{\circ}{\circ}$ & $\overrightarrow{0}$ & 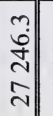 & ڤ̊. & $\begin{array}{l}\stackrel{+}{\dot{d}} \\
\stackrel{\mathrm{d}}{ }\end{array}$ & $\stackrel{-}{0}$ & $\stackrel{?}{\rightarrow}$ & ò & : & $\stackrel{\infty}{m}$ & הે & & & $\begin{array}{c}+ \\
+ \\
0 \\
\vdots \\
-1\end{array}$ & $\begin{array}{l}3 \\
\vdots \\
\infty \\
0 \\
0\end{array}$ & 2 \\
\hline 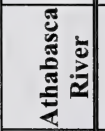 & & & $\begin{array}{l}0 \\
\stackrel{0}{0}\end{array}$ & & & $\stackrel{+}{-}$ & $\overrightarrow{\mathrm{i}}$ & $\frac{n}{2}$ & 0 & $\begin{array}{l}\overline{0} \\
\infty \\
\infty\end{array}$ & ?. & ర․ & 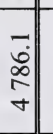 & & $\begin{array}{l}m \\
\dot{0} \\
\dot{q}\end{array}$ & $\stackrel{-}{0}$ & $\stackrel{+}{-}$ & $\left|\begin{array}{l}0 \\
0 \\
0 \\
n\end{array}\right|$ & $\begin{array}{l}0 \\
\\
\underline{\underline{n}}\end{array}$ & & ֶָ) & & & ¿̊. & & in \\
\hline 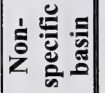 & & ชี & & $\begin{array}{l}0 \\
\stackrel{\Omega}{\simeq}\end{array}$ & $\because$ & $\begin{array}{l}n \\
\vdots \\
\vdots\end{array}$ & $\begin{array}{l}\infty \\
\stackrel{\infty}{m}\end{array}$ & & $\begin{array}{l}\infty \\
\tilde{\Xi} \\
0\end{array}$ & & $\stackrel{\circ}{\circ}$ & ఫे & & & $\underset{\stackrel{d}{d}}{\vec{f}}$ & ڤ̊ & $\begin{array}{l}\infty \\
\dot{\gamma} \\
\forall\end{array}$ & 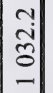 & 交 & & & & & in & $\dot{m}$ & $: \begin{array}{l}\infty \\
\propto \\
\varrho\end{array}$ \\
\hline 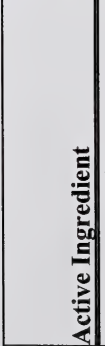 & 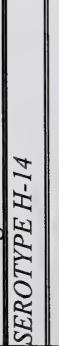 & 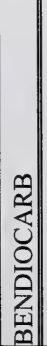 & 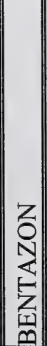 & 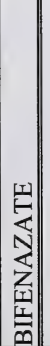 & 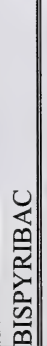 & 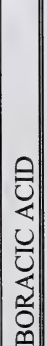 & \begin{tabular}{|l|}
$x$ \\
$x$ \\
0 \\
0 \\
0
\end{tabular} & 是 & 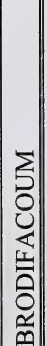 & \begin{tabular}{|c||} 
\\
0 \\
0 \\
0 \\
0 \\
0 \\
$\infty$
\end{tabular} & 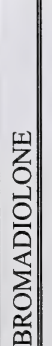 & 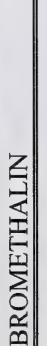 & 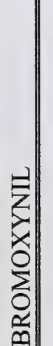 & 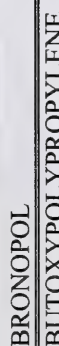 & 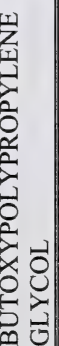 & $\begin{array}{l}z \\
0 \\
\vdots \\
n \\
\kappa\end{array}$ & \begin{tabular}{|l|}
$z$ \\
$z$ \\
$\vdots$ \\
$\vdots$ \\
$\vdots$ \\
\end{tabular} \mid & | & 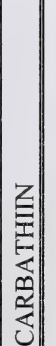 & 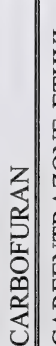 & 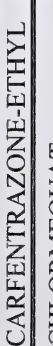 & 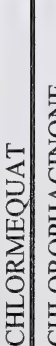 & 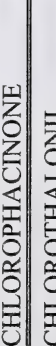 & 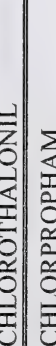 & 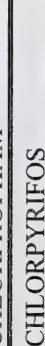 & 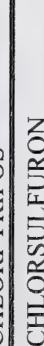 \\
\hline
\end{tabular}




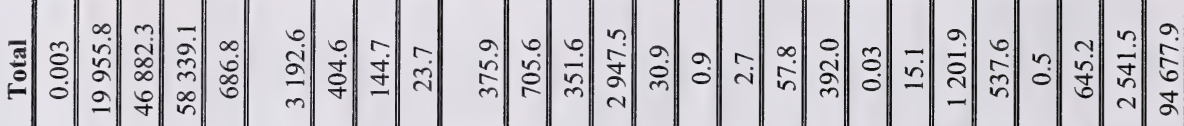

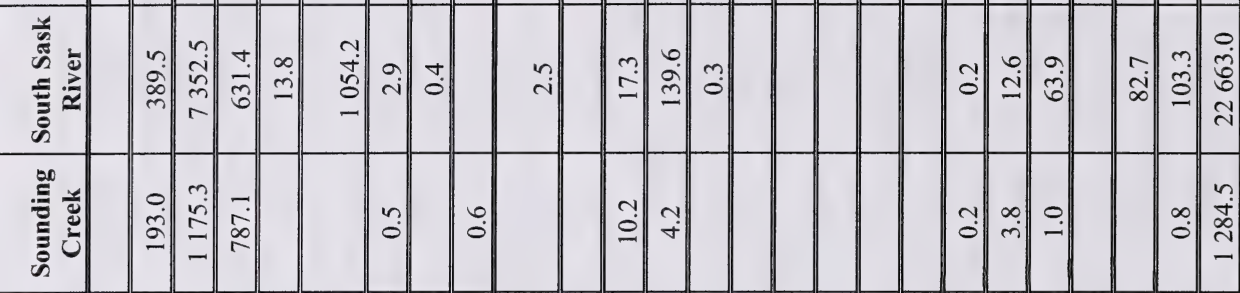

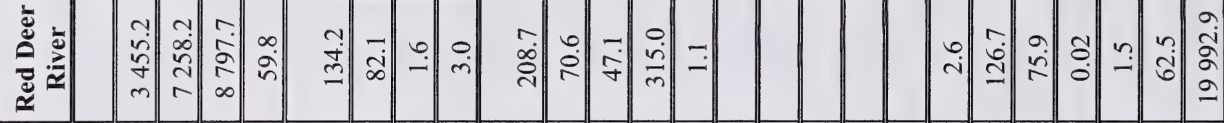

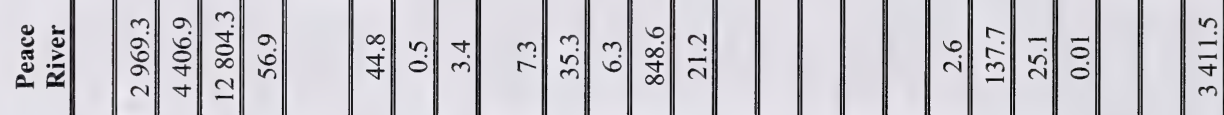

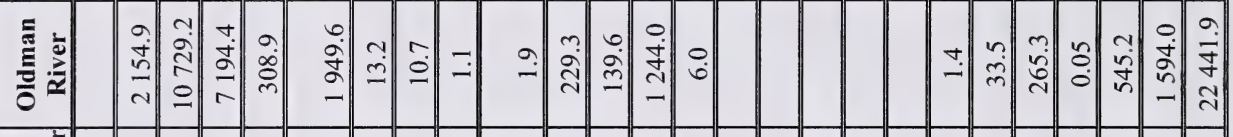

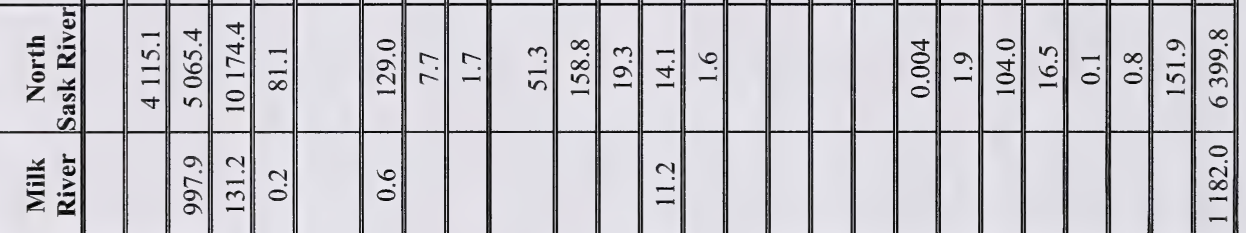

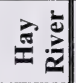

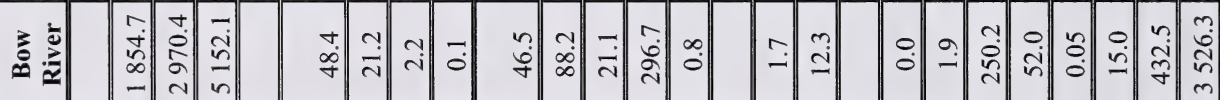

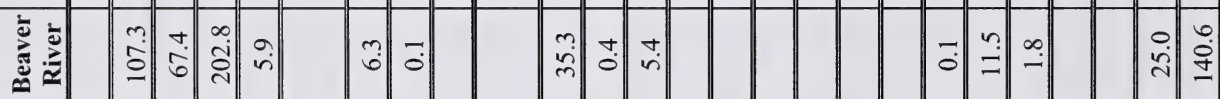

童竞

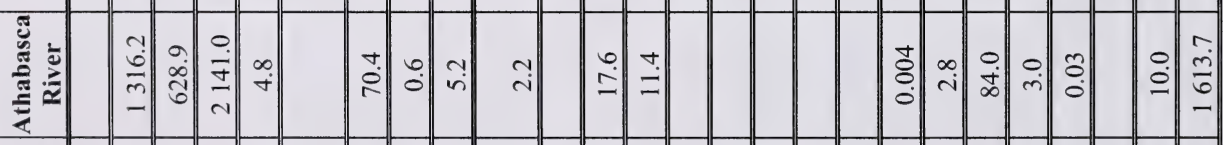

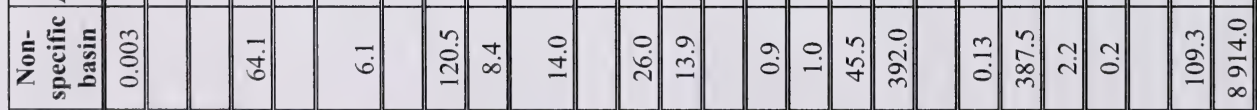

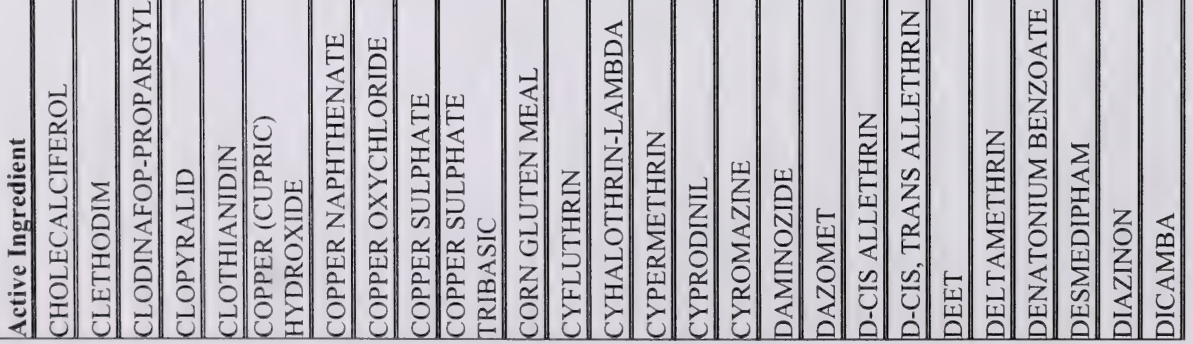




\begin{tabular}{|c|c|c|c|c|c|c|c|c|c|c|c|c|c|c|c|c|c|c|c|c|c|c|c|c|c|}
\hline है & $\begin{array}{c}n \\
i \\
i n\end{array}$ & 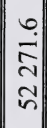 & ح̂. & vi & 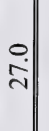 & \begin{tabular}{|l||}
$n$ \\
0 \\
0
\end{tabular} & 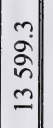 & 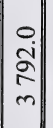 & 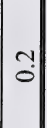 & 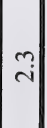 & 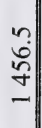 & $\stackrel{\infty}{-\infty}$ & $\stackrel{g}{ \pm}$ & oे & $\left|\begin{array}{c|}0 \\
\tilde{\alpha} \\
\infty \\
\text { లు }\end{array}\right|$ & $\mid \begin{array}{l}+ \\
+ \\
6 \\
n \\
m\end{array}$ & م.| & $\begin{array}{l}\infty \\
\pm \\
\pm\end{array}$ & $\begin{array}{l}0 \\
\text { ते } \\
m\end{array}$ & הุ & 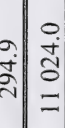 & $\mid \begin{array}{l}- \\
\tilde{n} \\
\infty \\
\tilde{\infty} \\
\tilde{\infty}\end{array}$ & 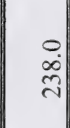 & $\mid \begin{array}{l}0 \\
0 \\
0 \\
0 \\
\sim \\
\sim\end{array}$ & $\frac{7}{\infty}$ \\
\hline 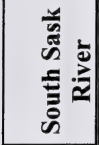 & $\vec{n}$ & 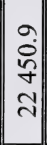 & ‥ & & & & $\begin{array}{l}n \\
\tilde{n} \\
\sim \\
-1\end{array}$ & \begin{tabular}{|c||} 
\\
ஸे \\
|
\end{tabular} & $\begin{array}{l}\tilde{8} \\
8 \\
0\end{array}$ & & $\begin{array}{l}\infty \\
0 \\
0 \\
0\end{array}$ & & $\stackrel{b}{6}$ & $\stackrel{-}{0}$ & \begin{tabular}{|c|}
-1 \\
$\hat{n}$ \\
$\infty$ \\
$m$
\end{tabular} & $\begin{array}{l}0 \\
0 \\
0 \\
0 \\
-\end{array}$ & & $?$ & m. & $\tilde{0}$ & ஃें & $\mid \begin{array}{l}\tilde{y} \\
\infty \\
z \\
= \\
=\end{array}$ & $\stackrel{+}{\circ}$ & $\mid \begin{array}{l}0 \\
i \\
-1\end{array}$ & 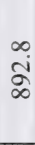 \\
\hline 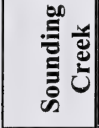 & $\stackrel{0}{\mathrm{r}}$ & $\mid$\begin{tabular}{c|c}
0 \\
$\dot{+}$ \\
$\tilde{n}$ \\
$m$
\end{tabular} & ฮี & & & & $\begin{array}{l}\overrightarrow{0} \\
\infty \\
m \\
-1\end{array}$ & & ¿े & & & & $\ddot{0}$ & $\begin{array}{l}-1 \\
0 \\
0\end{array}$ & 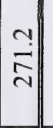 & & & $\begin{array}{l}-0 \\
0 \\
0\end{array}$ & & $\begin{array}{l}\tilde{\delta} \\
\hat{0}\end{array}$ & & $\frac{m}{m}$ & ন্. & & \\
\hline 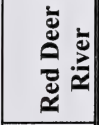 & \begin{tabular}{c||}
0 \\
$\dot{j}$ \\
$\infty$
\end{tabular} & $\mid$\begin{tabular}{l|}
0 \\
0 \\
0 \\
2 \\
$\sim$ \\
$\sim$
\end{tabular} & $-\frac{1}{6}$ & $\hat{i}$ & $\stackrel{\circ}{\stackrel{0}{-}}$ & & 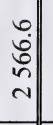 & \begin{tabular}{l||}
0 \\
$\infty$ \\
$\alpha$ \\
0
\end{tabular} & $\begin{array}{l}\tilde{\delta} \\
\tilde{8} \\
0\end{array}$ & & 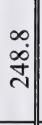 & $\stackrel{\infty}{-}$ & อे & 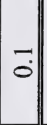 & \begin{tabular}{l|l||}
0 \\
के \\
in
\end{tabular} & $\begin{array}{c}0 \\
0 \\
\infty \\
i \\
\text { n. }\end{array}$ & & $\stackrel{0}{-}$ & $\begin{array}{l}\dot{v} \\
\dot{v}\end{array}$ & 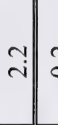 & 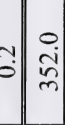 & $\mid \begin{array}{l}+ \\
\dot{8} \\
8 \\
\infty \\
\infty\end{array}$ & $\stackrel{\text { I }}{ \pm}$ & $\mid$\begin{tabular}{l|}
0 \\
0 \\
$i$ \\
$n$
\end{tabular} & \\
\hline 芯 & 守 & స̃. & 으. & & & & กี & 吕 & ธ్ర & & $\stackrel{+}{ \pm}$ & & $\begin{array}{l}\sim \\
\tilde{N}\end{array}$ & గọ & 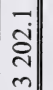 & $\begin{array}{l}0 \\
\dot{0} \\
\dot{y}\end{array}$ & & ठ். & $\begin{array}{c}\sim \\
\tilde{f}\end{array}$ & \begin{tabular}{l||l|l}
$\infty$ \\
0
\end{tabular} & & शे & $\stackrel{\widetilde{q}}{\tilde{q}}$ & & \\
\hline 咅 & ?̊? & \begin{tabular}{|c||}
0 \\
$\dot{j}$ \\
$\mathfrak{1}$ \\
-1
\end{tabular} & $\bar{\infty}$ & & $\because$ & & 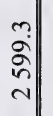 & $\mid \begin{array}{c}0 \\
0 \\
\\
-\end{array}$ & - & & 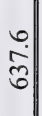 & & $\begin{array}{l}\infty \\
\stackrel{0}{0}\end{array}$ & ¿.| & \begin{tabular}{l||}
0 \\
0 \\
0 \\
0 \\
0 \\
0
\end{tabular} & $\begin{array}{l}m \\
8 \\
\text { ¿े }\end{array}$ & & $\stackrel{0}{-}$ & \begin{tabular}{l||l}
0 & 0. \\
- &.
\end{tabular} & $=$ & \begin{tabular}{l|l}
0 \\
$\dot{\sigma}$ \\
$\dot{\sigma}$
\end{tabular} & 客 & $\stackrel{\Im}{\triangle}$ & 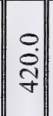 & $\begin{array}{l}\text { b } \\
\text { तु } \\
\text { in }\end{array}$ \\
\hline 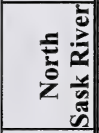 & $\begin{array}{c}\infty \\
m \\
m\end{array}$ & $\mid$\begin{tabular}{c|c}
+ \\
$\dot{m}$ \\
$\infty$
\end{tabular} & 号 & & & & 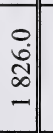 & 울 & ?ֶ. & & $\begin{array}{l}\infty \\
i \\
i\end{array}$ & & $\stackrel{\sim}{m}$ & ชุ| & \begin{tabular}{l|l|}
$m$ \\
0 \\
0 \\
0 \\
$m$
\end{tabular} & $\begin{array}{l}0 \\
\dot{0} \\
\infty \\
\infty \\
a\end{array}$ & & $\stackrel{\nabla}{r}$ & कें & ?ּ̧ & 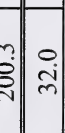 & $\begin{array}{l}0 \\
0 \\
0 \\
0 \\
n \\
-1\end{array}$ & $\stackrel{?}{=}$ & & \\
\hline 美京 & & ?. & & & & & $\stackrel{+}{\dot{m}}$ & & & & & & & & $\begin{array}{l}0 \\
8 \\
8\end{array}$ & & & & & 뭉 & & $\begin{array}{c}0 \\
\dot{j} \\
n\end{array}$ & $\stackrel{0}{-}$ & & \\
\hline 胥 & & & & & & & & & & & & & & & & & & & & & & & & & \\
\hline 包 & जें & $\begin{array}{l}\infty \\
0 \\
0 \\
0 \\
-1\end{array}$ & ñ & & & & 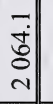 & $\begin{array}{l}0 \\
\text { à } \\
-\end{array}$ & :0 & 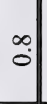 & $\begin{array}{l}\tilde{v} \\
\text { ฟิ }\end{array}$ & & $\hat{\text { ¿े. }}$ & 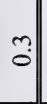 & $\stackrel{\vec{\Delta}}{\mathrm{i}}$ & & $\stackrel{0}{-}$ & ติ) & $\begin{array}{c}\stackrel{1}{ } \\
\tilde{J}\end{array}$ & $\stackrel{0}{\infty}$ & 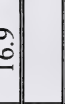 & $\begin{array}{c}\infty \\
\dot{1} \\
0 \\
0 \\
-\end{array}$ & 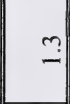 & 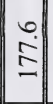 & \\
\hline 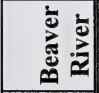 & ָึ. & & 9 & & & & $\begin{array}{l}0 \\
\infty \\
\infty\end{array}$ & & $\begin{array}{l}\tilde{8} \\
8 \\
0\end{array}$ & & & & $\stackrel{0}{\dot{m}}$ & $\begin{array}{l}+ \\
8 \\
0\end{array}$ & 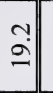 & & & $\overrightarrow{0}$ & & $\tilde{o}$ & & & & & \\
\hline 总 & $\stackrel{\infty}{2}$ & $\begin{array}{l}n \\
\\
\sim \\
\sim\end{array}$ & $\stackrel{n}{=}$ & & & & $\begin{array}{l}+ \\
\dot{b} \\
0 \\
-\end{array}$ & $\mid \begin{array}{c}0 \\
0 \\
i \\
i \\
\end{array}$ & $\begin{array}{l}-0 \\
0 \\
0\end{array}$ & & $\begin{array}{l}\infty \\
\dot{+}\end{array}$ & & $\stackrel{+}{\infty}$ & $\widetilde{\jmath}$ & 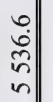 & $\stackrel{0}{\stackrel{+}{+}}$ & & ?. & $\stackrel{+}{\circ}$ & $\vec{m}$ & $\begin{array}{l}\stackrel{+}{\sim} \\
\stackrel{+}{\sim}\end{array}$ & 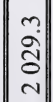 & $\begin{array}{l}\stackrel{\bullet}{\bullet} \\
\stackrel{-}{*}\end{array}$ & & \\
\hline 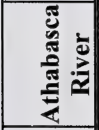 & $\stackrel{\searrow}{ \pm}$ & ì & के. & & & & 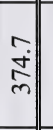 & 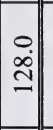 & $\begin{array}{l}\text { ○ิ } \\
\delta \\
0 \\
0\end{array}$ & & $\stackrel{0}{\circ}$ & & 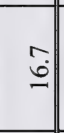 & $\begin{array}{l}\text { ô } \\
\text { ô }\end{array}$ & $\begin{array}{l}n \\
n \\
n \\
6\end{array}$ & $\begin{array}{l}0 \\
0 \\
\dot{\infty} \\
\infty\end{array}$ & & $\ddot{0}_{0}^{\circ}$ & & \begin{tabular}{l||l}
$\infty$ & \\
0 &
\end{tabular} & ș. & 㑏 & $?$ & & \\
\hline 方参 & $\begin{array}{c}0 \\
\dot{+} \\
\dot{\infty}\end{array}$ & $\begin{array}{c}0 \\
0 \\
0 \\
1 \\
i \\
n \\
\end{array}$ & $\begin{array}{l}0 \\
0 \\
\dot{g} \\
\end{array}$ & & $\begin{array}{l}? \\
0\end{array}$ & $\begin{array}{l}n \\
\stackrel{0}{0}\end{array}$ & - & & $\overrightarrow{0}$ & $\because$ & กิ & & & | & $=$ & $\begin{array}{l}0 \\
\\
0 \\
2 \\
i\end{array}$ & 이 & & $\stackrel{\sim}{\sim}$ & \begin{tabular}{l||c} 
ה \\
\end{tabular} & & & & त్ర & \\
\hline 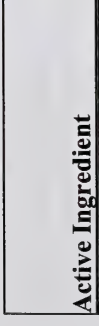 & 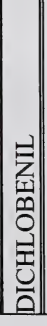 & 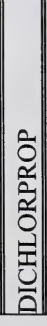 & 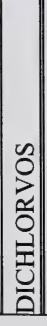 & 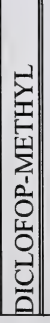 & (2) & 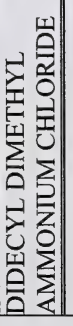 & 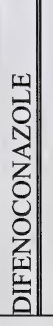 & 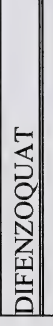 & 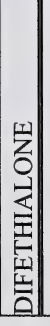 & 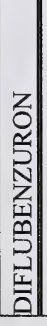 & 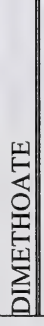 & 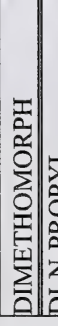 & 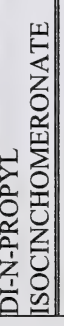 & 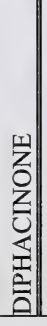 & 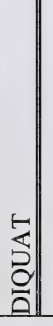 & $\begin{array}{l}z \\
0 \\
\vdots \\
\vdots \\
0\end{array}$ & 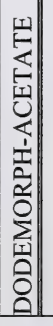 & 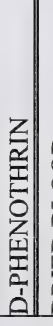 & 空 & 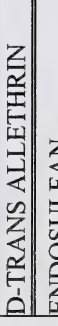 & 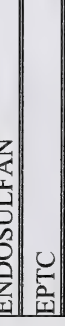 & 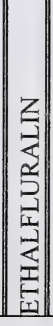 & 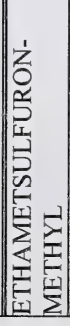 & 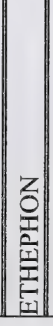 & 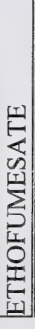 \\
\hline
\end{tabular}




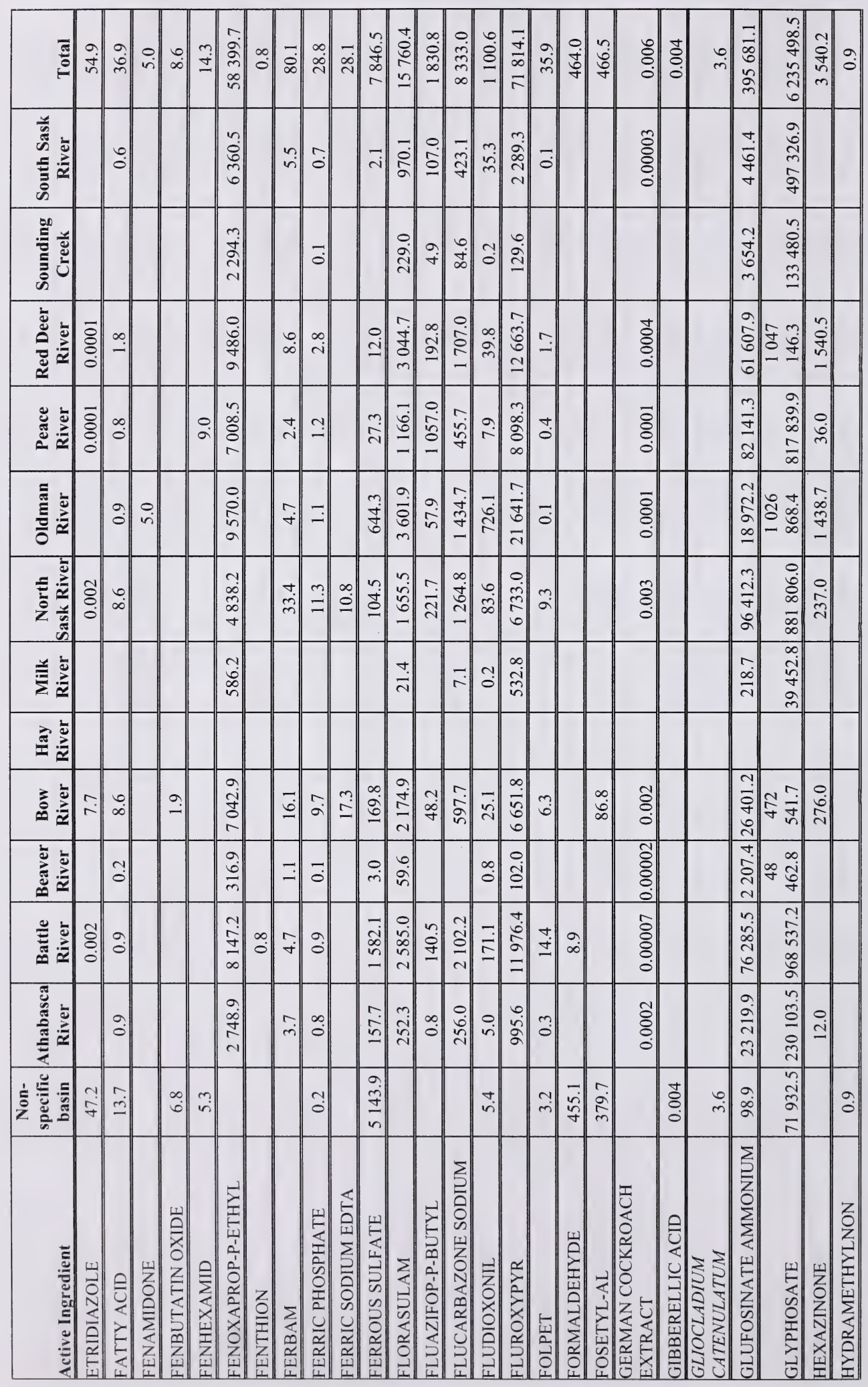




\begin{tabular}{|c|c|c|c|c|c|c|c|c|c|c|c|c|c|c|c|c|c|c|c|c|c|c|c|c|c|c|c|c|}
\hline$\stackrel{\overrightarrow{0}}{0}$ & $\begin{array}{l}? \\
8 \\
8 \\
\vdots \\
\vdots\end{array}$ & $\begin{array}{l}a \\
\frac{\pi}{2} \\
-\end{array}$ & $\begin{array}{l}5 \\
2 \\
0 \\
0\end{array}$ & \begin{tabular}{l||}
- \\
$\infty$ \\
$\sim$ \\
$\infty$ \\
$m$
\end{tabular} & テे & $\begin{array}{l}\frac{7}{5} \\
\frac{m}{n}\end{array}$ & $\stackrel{\square}{-}$ & n & \begin{tabular}{l|}
0 \\
$\dot{7}$ \\
$\vdots$
\end{tabular} & $\frac{n}{n}$ & $\begin{array}{l}\tilde{\sigma} \\
\text { f } \\
\text { m }\end{array}$ & $\begin{array}{l}\infty \\
\infty \\
\infty\end{array}$ & 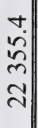 & $\frac{n}{n}$ & $\begin{array}{l}\infty \\
i \\
\Omega \\
\infty \\
\infty \\
0 \\
-\end{array}$ & 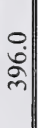 & $\begin{array}{c}0 \\
-1 \\
N \\
m\end{array}$ & $\begin{array}{l}a \\
\frac{a}{m} \\
m \\
q\end{array}$ & a! & $\begin{array}{l}= \\
\dot{\square} \\
=\end{array}$ & $\begin{array}{l}- \\
n \\
m \\
+\end{array}$ & n & \begin{tabular}{l||}
$\nabla$ \\
0 \\
\\
\end{tabular} & $\begin{array}{l}\infty \\
\dot{t}\end{array}$ & $\vec{I}$ & $\begin{array}{l}n \\
0 \\
0 \\
0\end{array}$ & $\frac{\vec{\sim}}{\sim}$ & $\begin{array}{l}\infty \\
\infty \\
\infty \\
\infty \\
\infty\end{array}$ \\
\hline 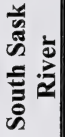 & $\begin{array}{l}\text { N } \\
\text { ㄴ } \\
-\end{array}$ & $\begin{array}{l}n \\
g \\
\delta\end{array}$ & $\frac{n}{2}$ & & ? & $\begin{array}{l}9 \\
\dot{b} \\
\infty\end{array}$ & & & $\begin{array}{c}N \\
\text { m. }\end{array}$ & $\begin{array}{l}0 \\
\text { n }\end{array}$ & $\frac{n}{n}$ & & $\begin{array}{l}\sigma \\
\approx \\
\sim\end{array}$ & & $\begin{array}{l}\infty \\
\\
n \\
\end{array}$ & & $\begin{array}{l}- \\
\infty \\
\infty\end{array}$ & $\begin{array}{l}n \\
\vdots \\
m \\
m\end{array}$ & & $\begin{array}{l}a \\
a \\
\text { y. }\end{array}$ & 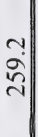 & $\stackrel{0}{-}$ & & $\begin{array}{l}\text { N } \\
\infty \\
\text { N }\end{array}$ & & & $\begin{array}{l}\infty \\
0\end{array}$ & $\stackrel{\Xi}{\check{J}}$ \\
\hline 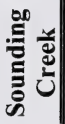 & $\begin{array}{l}\text { ல } \\
\text { ภิ } \\
\text { ปิ }\end{array}$ & $\begin{array}{l}\nabla \\
\infty \\
=\end{array}$ & $\begin{array}{l}+ \\
\infty \\
\dot{\sigma}\end{array}$ & & ำ & तi & & & & 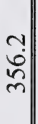 & $\begin{array}{l}\sim \\
\stackrel{\infty}{0}\end{array}$ & & - & & $\begin{array}{l}N \\
0 \\
0 \\
\text { ป̂. }\end{array}$ & & ก & $\begin{array}{l}n \\
\Omega \\
\Omega \\
\end{array}$ & & $\hat{0}$ & ¿ & $\begin{array}{l} \pm \\
0 \\
0\end{array}$ & & & & & $\begin{array}{l}N \\
0\end{array}$ & ? \\
\hline 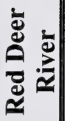 & $\begin{array}{l}\hat{n} \\
\tilde{\sigma} \\
=\end{array}$ & $\begin{array}{l}N \\
\infty \\
\sigma\end{array}$ & $\begin{array}{l}n \\
b \\
\infty \\
\infty\end{array}$ & $\begin{array}{l}+ \\
N\end{array}$ & $\begin{array}{l}+ \\
\text { ரे }\end{array}$ & $\begin{array}{l}\infty \\
\dot{n} \\
\infty \\
\sim \\
\simeq\end{array}$ & & & $\stackrel{-}{-}$ & \begin{tabular}{l|l}
0 \\
9 \\
$m$ \\
$m$
\end{tabular} & 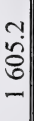 & & 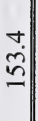 & 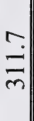 & $\begin{array}{l}-1 \\
2 \\
m \\
\dot{0} \\
-\end{array}$ & & \begin{tabular}{l||}
+ \\
\multirow{2}{*}{} \\
\end{tabular} & $\begin{array}{l}\stackrel{r}{r} \\
\text { m } \\
\text { m }\end{array}$ & & \begin{tabular}{l}
$\searrow$ \\
\multirow{2}{\sim}{}
\end{tabular} & 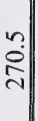 & $n$ & $\begin{array}{c}0 \\
\infty \\
+\end{array}$ & $\hat{\sigma}$ & & & $\begin{array}{l}\infty \\
\sim i\end{array}$ & 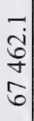 \\
\hline 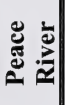 & $\begin{array}{l}\text { No } \\
\stackrel{0}{\sigma} \\
\underline{0}\end{array}$ & $\begin{array}{l}9 \\
\dot{0} \\
0\end{array}$ & $\begin{array}{l}\sim \\
\cdots \\
m \\
m\end{array}$ & $\begin{array}{l}m \\
n \\
\infty\end{array}$ & ڤ̊ & $\begin{array}{l}0 \\
\overline{6} \\
\text { ㄱ. } \\
= \\
=\end{array}$ & & & $m$ & $\begin{array}{c}0 \\
\text { Ni } \\
\end{array}$ & ๓̇ & & $\begin{array}{c}\sim \\
\stackrel{\sim}{\sim}\end{array}$ & $\stackrel{n}{0}$ & $\begin{array}{l}\infty \\
\tilde{n} \\
\infty \\
\infty \\
n\end{array}$ & $\begin{array}{l}\infty \\
\infty \\
\dot{+}\end{array}$ & $\begin{array}{l}0 \\
0\end{array}$ & $\begin{array}{l}5 \\
\dot{5} \\
\text { N }\end{array}$ & & $\frac{N}{v}$ & $\begin{array}{l}+ \\
8 \\
8\end{array}$ & $\stackrel{v}{m}$ & & $\stackrel{0}{-1}$ & $\begin{array}{l}n \\
0\end{array}$ & & $\stackrel{+}{-}$ & 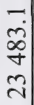 \\
\hline 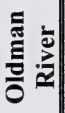 & $\begin{array}{l}0 \\
\infty \\
0 \\
\infty \\
0 \\
0\end{array}$ & $\begin{array}{l}0 \\
0 \\
0 \\
\infty \\
-1\end{array}$ & $\begin{array}{l}+ \\
\text { ஸे } \\
\infty \\
\text { ป } \\
-\end{array}$ & $\begin{array}{l}0 \\
\text { ते }\end{array}$ & $\begin{array}{l}n \\
\text { ป̧ } \\
\text { ते }\end{array}$ & 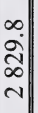 & & & & $\begin{array}{l}+ \\
i \\
\infty \\
-\end{array}$ & $\begin{array}{l}n \\
\sim \\
\infty \\
m \\
\dot{m}\end{array}$ & $\begin{array}{l}\infty \\
6 \\
\infty \\
\infty\end{array}$ & 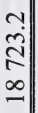 & m. & $\begin{array}{l}n \\
n \\
m \\
0 \\
=\end{array}$ & $\begin{array}{l}\infty \\
\dot{I}\end{array}$ & ? & $\begin{array}{l}0 \\
\infty \\
\infty \\
\infty \\
\infty\end{array}$ & & $\begin{array}{l}\infty \\
\vdots \\
\vdots\end{array}$ & $\begin{array}{l}\infty \\
-\infty \\
\infty \\
N\end{array}$ & $\begin{array}{l}\infty \\
i\end{array}$ & $\begin{array}{l}0 \\
0 \\
0\end{array}$ & $\begin{array}{l}0 \\
\dot{0}\end{array}$ & & & 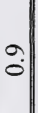 & 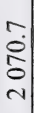 \\
\hline$=\frac{\bar{a}}{2}$ & $\begin{array}{l}\infty \\
8 \\
8 \\
9 \\
1\end{array}$ & $\begin{array}{l}a \\
\infty \\
\infty\end{array}$ & $\begin{array}{l}0 \\
\dot{j} \\
m\end{array}$ & $\begin{array}{l}6 \\
\varnothing \\
\infty\end{array}$ & $\stackrel{m}{\sim}$ & 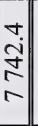 & & & ä & $\begin{array}{l}\text { v } \\
\dot{t} \\
m\end{array}$ & \begin{tabular}{c}
$\sim$ \\
\multirow{J}{*}{} \\
-
\end{tabular} & & $\begin{array}{l}r \\
\infty \\
0 \\
m\end{array}$ & 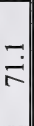 & $\begin{array}{l}- \\
\infty \\
\\
\infty \\
\infty\end{array}$ & $\begin{array}{l}n \\
\sim \\
\sim\end{array}$ & 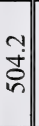 & $\begin{array}{l}\infty \\
\dot{m} \\
\dot{m} \\
0\end{array}$ & ๙̃. & $\begin{array}{l}n \\
0 \\
m\end{array}$ & $\begin{array}{l}a \\
\text { ñ. }\end{array}$ & $\begin{array}{l}m \\
\infty \\
\dot{\gamma}\end{array}$ & $\frac{1}{6}$ & 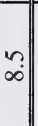 & & & $\begin{array}{l}\infty \\
i\end{array}$ & $\begin{array}{l}\frac{1}{\infty} \\
\frac{\infty}{0} \\
m\end{array}$ \\
\hline 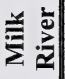 & $\begin{array}{l}\forall \\
\stackrel{+}{+}\end{array}$ & $\begin{array}{l}0 \\
-\end{array}$ & $\begin{array}{l}0 \\
- \\
-1\end{array}$ & & $\begin{array}{l}0 \\
0 \\
0\end{array}$ & & & & & & $\begin{array}{l}0 \\
\dot{t} \\
\qquad\end{array}$ & & & تُ & $\frac{\tilde{r}}{\mathrm{r}}$ & & $\begin{array}{l}m \\
\text { ri }\end{array}$ & $\begin{array}{l}\infty \\
\sim \\
n \\
\end{array}$ & & $\begin{array}{l}0 \\
0\end{array}$ & $\begin{array}{l}\text { ते } \\
\text { in }\end{array}$ & & & & & & & \\
\hline
\end{tabular}

\section{密}

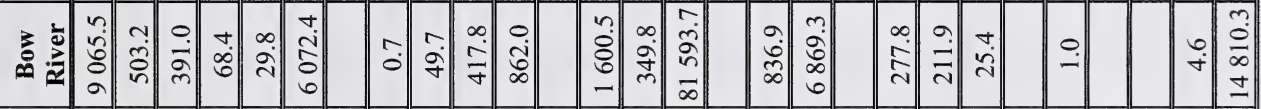

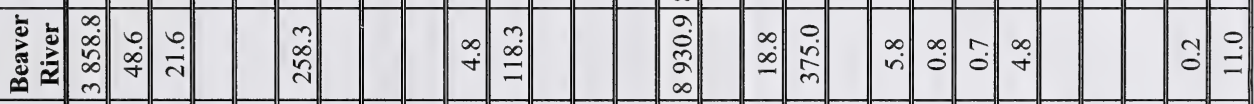

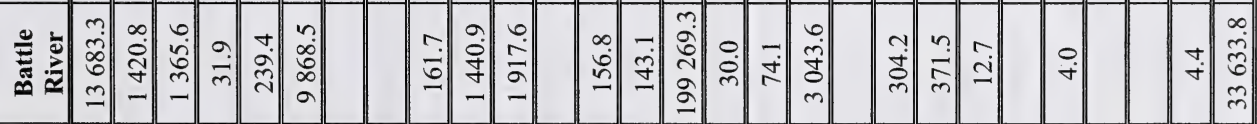

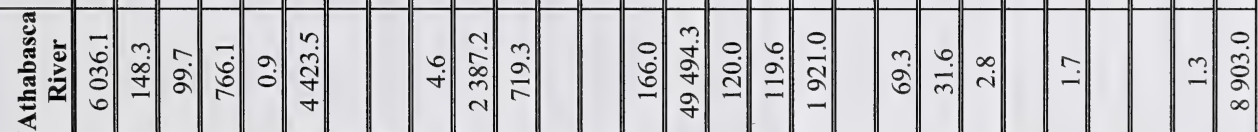

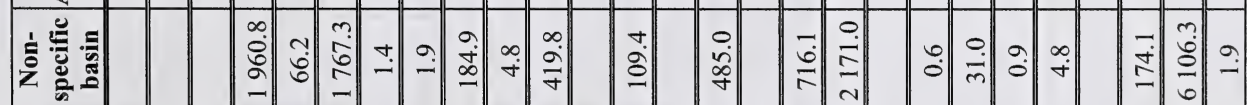

Non 


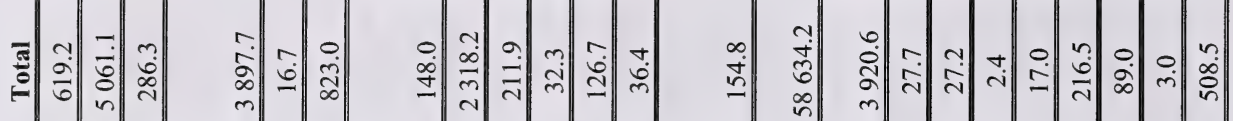

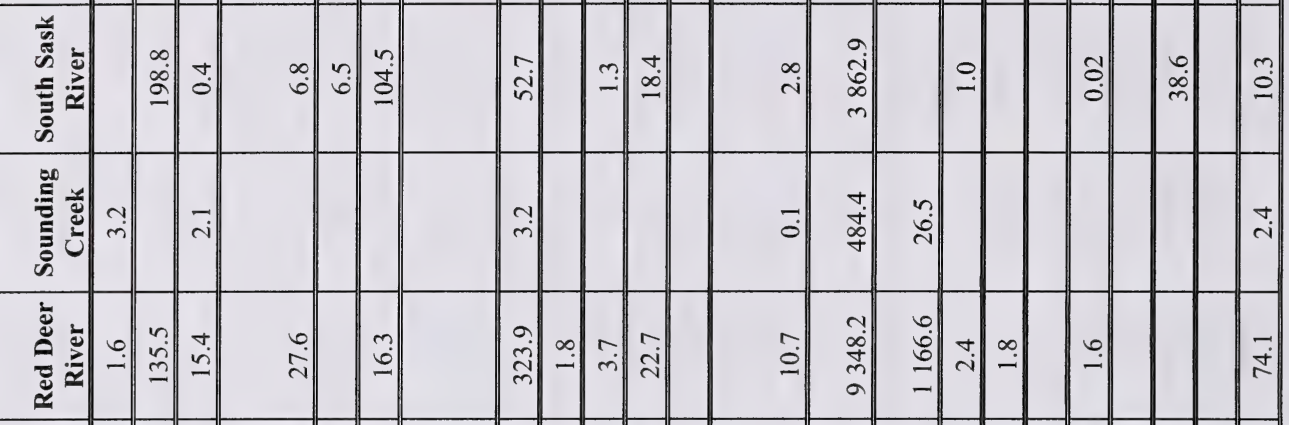

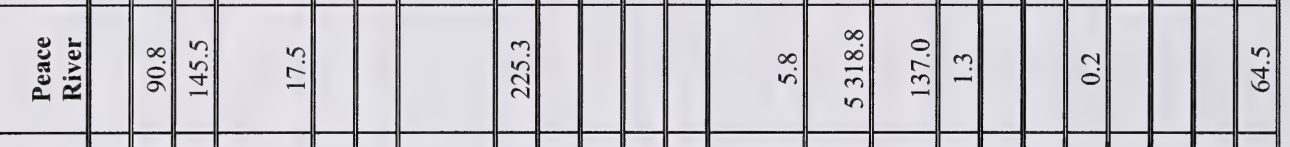

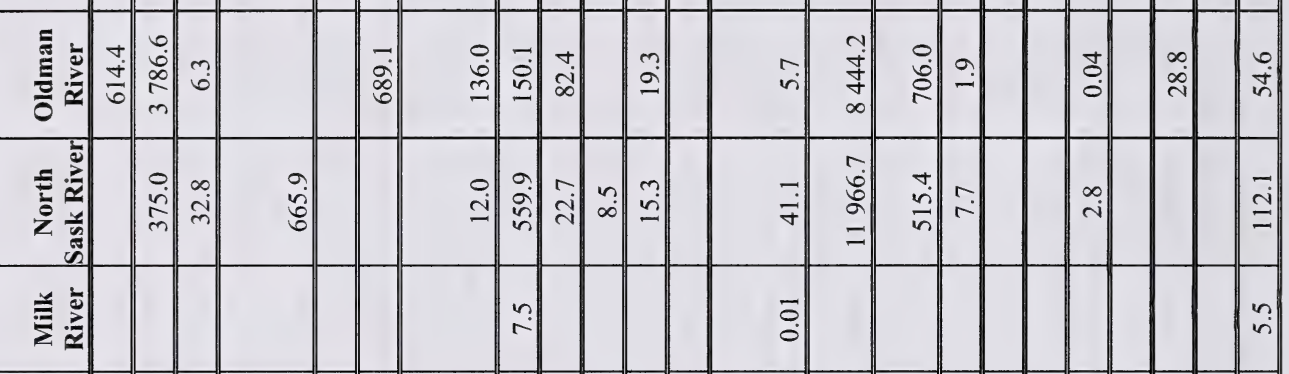

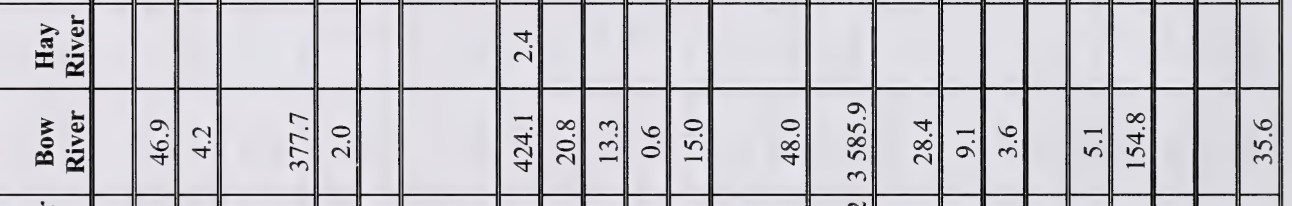

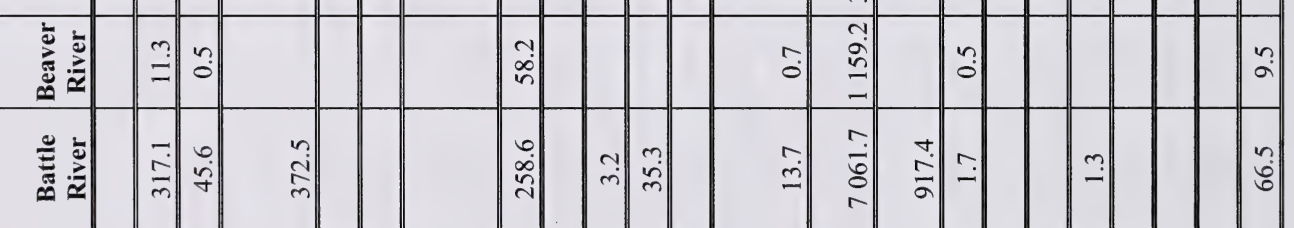

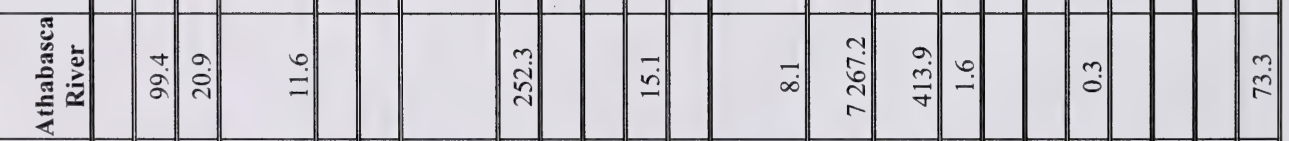

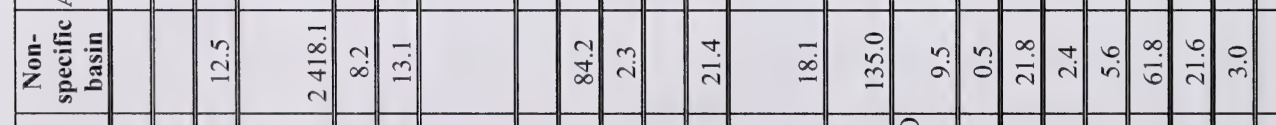

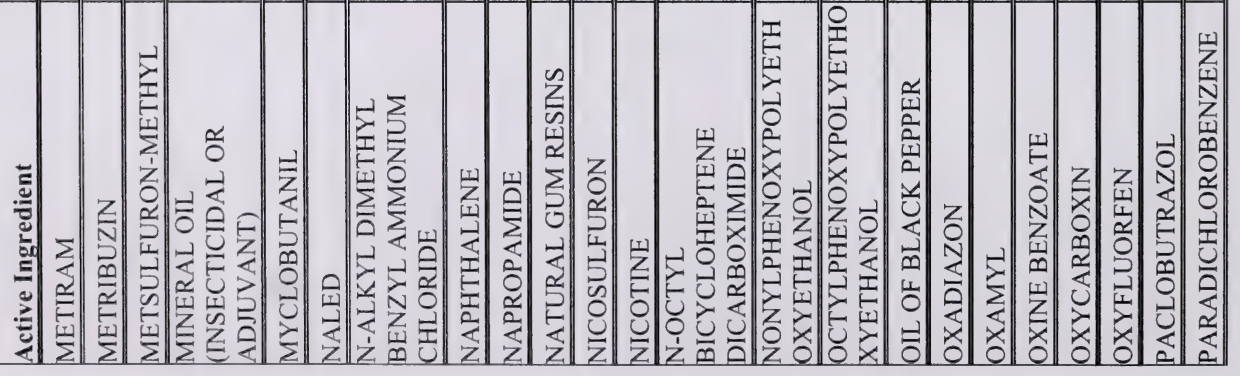




\begin{tabular}{|c|c|c|c|c|c|c|c|c|c|c|c|c|c|c|c|c|c|c|c|c|c|c|c|}
\hline 홈 & $\begin{array}{l}\hat{\infty} \\
\infty \\
\infty \\
\infty \\
\infty\end{array}$ & 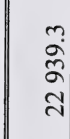 & $\begin{array}{l}0 \\
\stackrel{\Delta}{\mathbf{I}} \\
-\end{array}$ & (1) & $\mid \begin{array}{l}\hat{a} \\
\tilde{o} \\
-1 \\
-1\end{array}$ & $\mid \begin{array}{l}r \\
\infty \\
0 \\
0 \\
n \\
0 \\
0\end{array}$ & 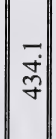 & $\mid \begin{array}{l}n \\
n \\
n \\
0 \\
o \\
y\end{array}$ & ते & •) & $\begin{array}{ll}-1 \\
\\
\end{array}$ & \begin{tabular}{l|l}
$\sim$ & \\
& \\
& \multicolumn{1}{c}{} \\
&
\end{tabular} & $-\mid$ & $\begin{array}{l}3 \\
\vdots \\
8 \\
-1\end{array}$ & 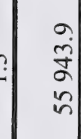 & $\stackrel{m}{i}$ & $\stackrel{m}{\hat{\alpha}}$ & $\left|\begin{array}{c}n \\
\vdots \\
\vdots \\
\infty\end{array}\right|$ & 嵩 & \begin{tabular}{l|}
0 \\
$i$ \\
$m$
\end{tabular} & की & $\mid \begin{array}{c}n \\
n \\
\infty \\
0 \\
0 \\
n \\
n\end{array}$ & $\frac{m}{\bar{q}}$ \\
\hline 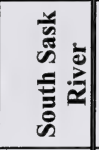 & $\begin{array}{l}\stackrel{0}{\dot{b}} \\
m \\
m\end{array}$ & 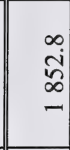 & $\stackrel{0}{\circ}$ & $\bar{c}$ & $\mid$\begin{tabular}{l|l}
$\infty$ \\
$\stackrel{\sim}{\sim}$
\end{tabular} & $\left|\begin{array}{c}r \\
\mathfrak{c} \\
0 \\
a\end{array}\right|$ & n. & : & $=$ & $\hat{o}$ & $\stackrel{\sim}{2}$ & $\stackrel{\infty}{\sim}$ & 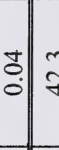 & 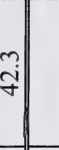 & लై & & $\stackrel{\sim}{\sim}$ & $\begin{array}{l}n \\
n \\
n \\
\infty\end{array}$ & & & & 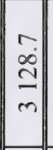 & \\
\hline | & $\begin{array}{l}m \\
0 \\
m \\
n\end{array}$ & $\stackrel{\stackrel{+}{\mathrm{d}}}{=}$ & & & $\vec{i}$ & 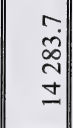 & & & & $\stackrel{\sim}{\sim}$ & \begin{tabular}{l|l}
0 \\
$:$
\end{tabular} & 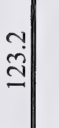 & & $\begin{array}{l}\text { ? } \\
\varrho\end{array}$ & $\overrightarrow{\frac{m}{\sigma}}$ & & & & & & & $\frac{9}{6}$ & : \\
\hline 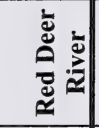 & $\begin{array}{l}\overline{\bar{a}} \\
\bar{a} \\
\bar{m}\end{array}$ & 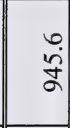 & $\begin{array}{l}0 \\
\dot{0} \\
\dot{n}\end{array}$ & $\mid$\begin{tabular}{c|}
0 \\
$\dot{q}$ \\
$\dot{\gamma}$
\end{tabular} & àd & 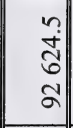 & & ?̊. & तi & & \begin{tabular}{l|l}
+ & \\
\multirow{d}{*}{} & $\vdots$ \\
m)
\end{tabular} & \begin{tabular}{l|l}
$m$ & \\
$\infty$ & \\
0 & \\
0 & $=$ \\
$=$ &
\end{tabular} & 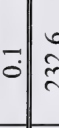 & $\begin{array}{c}0 \\
\text { ते } \\
\end{array}$ & $\begin{array}{l}0 \\
n \\
n \\
0 \\
0\end{array}$ & & 竎 & & & $\begin{array}{l}0 \\
\text { in } \\
\text { m. }\end{array}$ & & $\begin{array}{l}+ \\
\dot{b} \\
\tilde{n} \\
\simeq\end{array}$ & 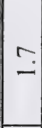 \\
\hline 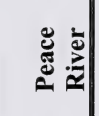 & 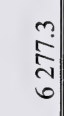 & $\begin{array}{l}r \\
\tilde{n} \\
m\end{array}$ & in & & \begin{tabular}{l|l}
$\infty$ \\
$\dot{q}$ \\
$\dot{q}$
\end{tabular} & $\begin{array}{l}\Upsilon 1 \\
\dot{J} \\
\infty \\
0 \\
0\end{array}$ & & & \begin{tabular}{l|l}
0 \\
0
\end{tabular} & & 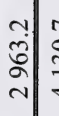 & \begin{tabular}{l|l}
$\hat{0}$ \\
$\tilde{\partial}$ \\
$\vec{\gamma}$
\end{tabular} & \begin{tabular}{ll|l}
0 \\
0
\end{tabular} & $=$ & $\begin{array}{l}0 \\
\dot{\vdots} \\
\vdots \\
a\end{array}$ & & ฉి & & & & & 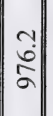 & $\stackrel{.}{-}$ \\
\hline 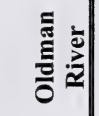 & 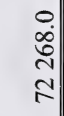 & $\begin{array}{l}+ \\
\dot{0} \\
\infty \\
i \\
n\end{array}$ & $\mid \begin{array}{l}0 \\
0 \\
0 \\
n \\
-1 \\
-1\end{array}$ & $\mid \begin{array}{c}n \\
n \\
\infty \\
\infty \\
0\end{array}$ & $\mid$\begin{tabular}{l||}
0 \\
$\dot{d}$ \\
\end{tabular} & $\begin{array}{l}0 \\
0 \\
\vdots \\
0 \\
\dot{J}\end{array}$ & $\mid$\begin{tabular}{|l||}
$\sim$ \\
\\
\end{tabular} & \begin{tabular}{|c||}
0 \\
$\tilde{s}$ \\
$\sim$ \\
$o$ \\
$\dot{y}$
\end{tabular} & $?$ & & \begin{tabular}{l|l}
$\infty$ & \\
0 & \\
&
\end{tabular} & 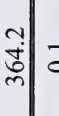 & $\overrightarrow{0}$ & $m$ & $\begin{array}{l}\infty \\
\vdots \\
\hat{n} \\
i \\
n\end{array}$ & & $\stackrel{0}{\stackrel{m}{m}}$ & & & & & 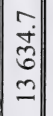 & $\because$ \\
\hline 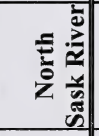 & $\begin{array}{l}\tilde{j} \\
\tilde{s} \\
\underline{n}\end{array}$ & $\begin{array}{l}0 \\
\text { तె } \\
\text { ते }\end{array}$ & $\begin{array}{c}0 \\
\infty \\
\infty \\
m\end{array}$ & & ר̦. & 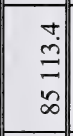 & $\infty$ & & $\partial \vec{\infty}$ & & 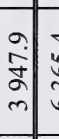 & 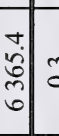 & $\stackrel{?}{0}$ & $\begin{array}{c} \\
\text { iे } \\
m^{2}\end{array}$ & $\begin{array}{l}n \\
\infty \\
n \\
\simeq \\
\simeq\end{array}$ & & 它 & & & & & $\begin{array}{c}0 \\
\infty \\
\infty \\
\infty \\
m\end{array}$ & i \\
\hline 美焉 & $\begin{array}{l}0 \\
0 \\
0 \\
0 \\
-\end{array}$ & & & & \begin{tabular}{ll|l}
0 \\
0 \\
0
\end{tabular} & 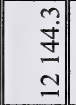 & & & & & $\stackrel{0}{\circ}$ & & I & 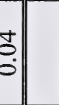 & & & & & & & & mे & ¿ \\
\hline 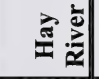 & & & & & & & & & & & & & & & & & & & & & & & \\
\hline 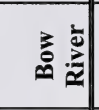 & 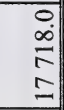 & $\begin{array}{l}\infty \\
\stackrel{\infty}{0} \\
\stackrel{0}{0}\end{array}$ & $\mid \begin{array}{l}0 \\
\infty\end{array}$ & & $\begin{array}{l}n \\
\\
\end{array}$ & $\begin{array}{l}-1 \\
0 \\
0 \\
0 \\
0\end{array}$ & $\begin{array}{l}\text { : } \\
\stackrel{\text { L }}{ }\end{array}$ & & $\stackrel{?}{+}$ & & 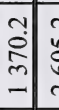 & 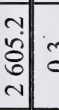 & $\stackrel{m}{0} \stackrel{m}{\approx}$ & $\begin{array}{c}m \\
\text { mi } \\
m\end{array}$ & $\begin{array}{l}-\bar{i} \\
\hat{\delta} \\
\text { n. }\end{array}$ & $\overrightarrow{\mathrm{n}}$ & $\stackrel{+}{\stackrel{+}{N}}$ & & 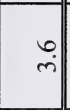 & & & 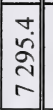 & $\stackrel{m}{r}$ \\
\hline 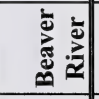 & $\begin{array}{l}0 \\
0 \\
0 \\
- \\
\end{array}$ & & & & $\stackrel{9}{\longrightarrow}$ & $\begin{array}{l}0 \\
\tilde{n} \\
\dot{y} \\
-1\end{array}$ & & & $\tilde{o}$ & & \begin{tabular}{l|l}
0 \\
\\
\end{tabular} & $\stackrel{a}{a}$ & 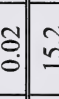 & vis & $\frac{n}{\sim}$ & & î & & & & & \begin{tabular}{|l|} 
\\
$\infty$ \\
$\infty$ \\
$\infty$
\end{tabular} & ชี \\
\hline 总 & $\begin{array}{l}n \\
\tilde{n} \\
\tilde{N} \\
\tilde{N}\end{array}$ & $\begin{array}{l}\infty \\
\mathbb{N} \\
\end{array}$ & $\begin{array}{l}0 \\
8 \\
8\end{array}$ & & $\begin{array}{l}0 \\
9 \\
9\end{array}$ & \begin{tabular}{l||}
$\tilde{n}$ \\
$\tilde{2}$ \\
$\tilde{o}$ \\
0
\end{tabular} & & & $\stackrel{m}{-}$ & & 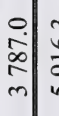 & $\begin{array}{l}\text { ? } \\
\text { ?. } \\
\text { in }\end{array}$ & $\overline{0}$ & $\begin{array}{l}0 \\
\infty \\
\infty\end{array}$ & $\begin{array}{l}+ \\
\text { ì } \\
\text { } \\
0\end{array}$ & & $\stackrel{n}{=}$ & & & & & $\begin{array}{c}- \\
\tilde{y} \\
n \\
n\end{array}$ & $\cong$ \\
\hline 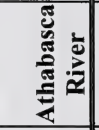 & $\begin{array}{l}\infty \\
\stackrel{\infty}{n} \\
\tilde{n} \\
m\end{array}$ & $\begin{array}{l}\infty \\
\stackrel{\infty}{0} \\
\stackrel{0}{0}\end{array}$ & & & $\hat{\infty}$ & 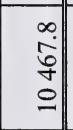 & & & $\stackrel{\circ}{-}$ & & 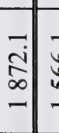 & 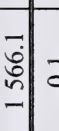 & $\overrightarrow{0}$ & $\stackrel{0}{\circ}$ & 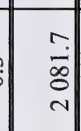 & & $\begin{array}{l}0 \\
\stackrel{\mathbf{i}}{\sim}\end{array}$ & & & & & \begin{tabular}{|l||} 
\\
\\
\end{tabular} & $\stackrel{+}{-}$ \\
\hline 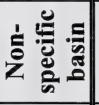 & & & $\stackrel{\circ}{\mathrm{i}}$ & & \begin{tabular}{l||}
$\overrightarrow{0}$ \\
$\stackrel{0}{y}$
\end{tabular} & & & & & & 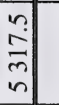 & & \begin{tabular}{l|l}
2 & 0 \\
0 & $\infty$ \\
0 & $\infty$
\end{tabular} & \begin{tabular}{|l|}
0 \\
$\infty$ \\
i
\end{tabular} & & $\begin{array}{l}\stackrel{N}{\infty} \\
\infty\end{array}$ & & & 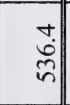 & & $\begin{array}{l}\stackrel{0}{\infty} \\
-\end{array}$ & 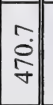 & $\begin{array}{l}\infty \\
\ddot{\sim} \\
\ddot{\sim}\end{array}$ \\
\hline & 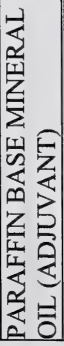 & 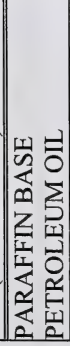 & 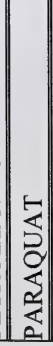 & 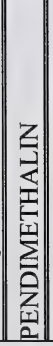 & $\mid$ & 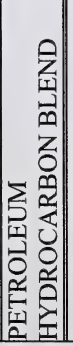 & | & 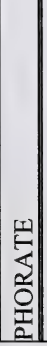 & 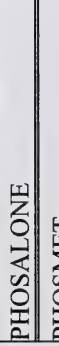 & 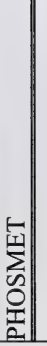 & 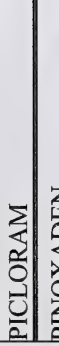 & 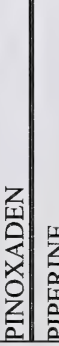 & 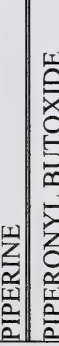 & 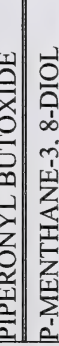 & 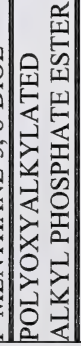 & 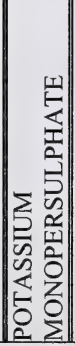 & 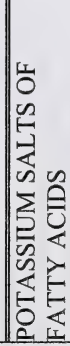 & $\mid$ & 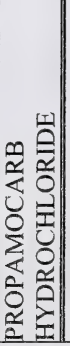 & 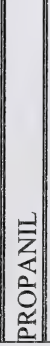 & $\left|\begin{array}{l|}0 \\
0 \\
0 \\
2 \\
0 \\
1 \\
0 \\
0 \\
2 \\
2\end{array}\right|$ & $\mid$\begin{tabular}{l|}
0 \\
0 \\
0 \\
0 \\
$\vdots$ \\
0 \\
0 \\
0 \\
0 \\
2 \\
2
\end{tabular} & 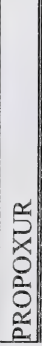 \\
\hline
\end{tabular}




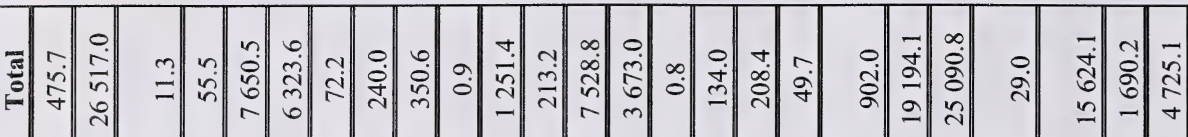

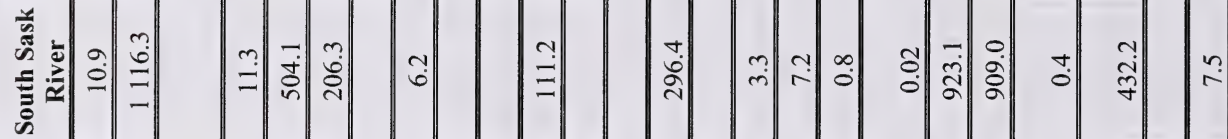

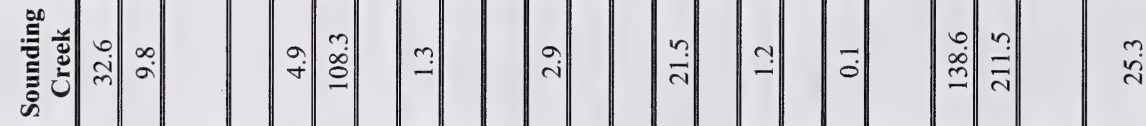

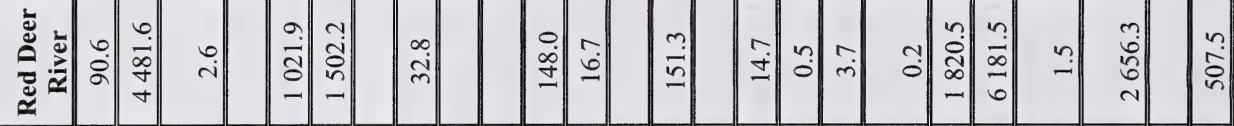

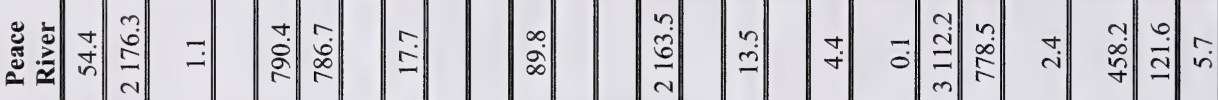

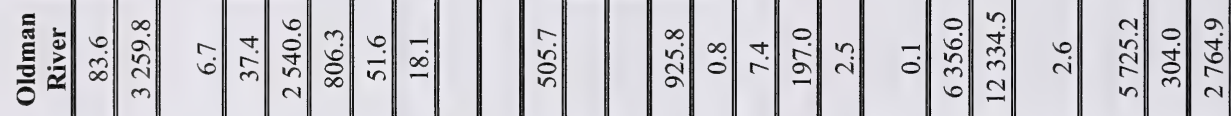

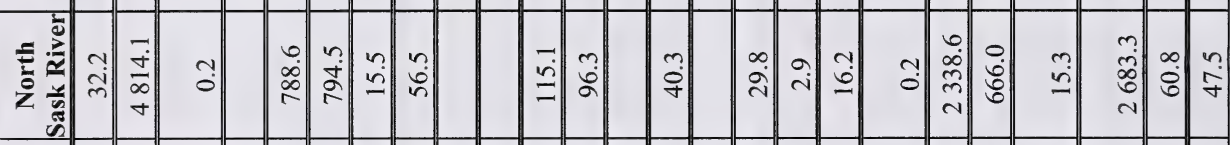

| $\quad$ (n)

(

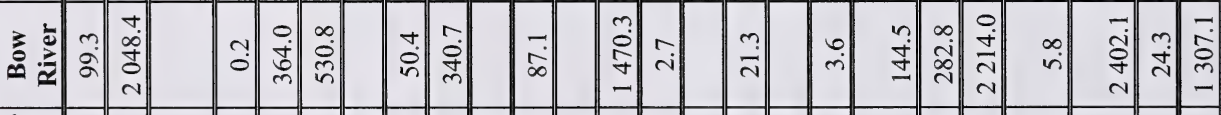

ब1

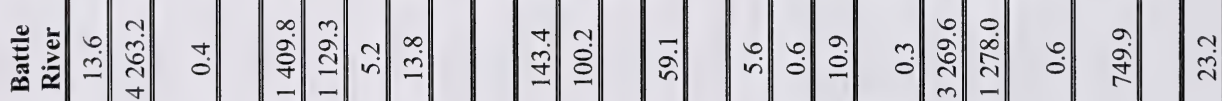

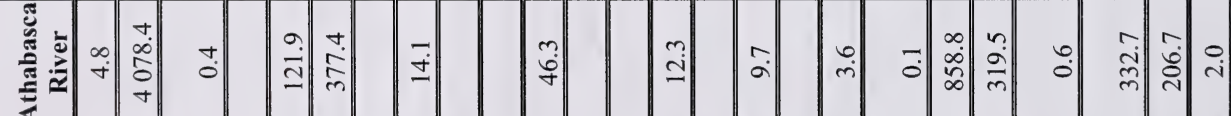

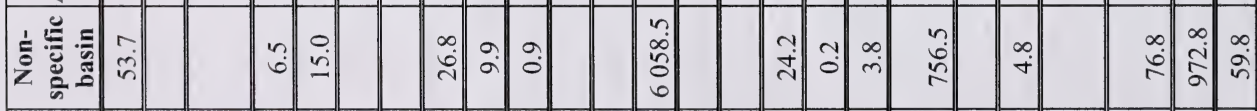

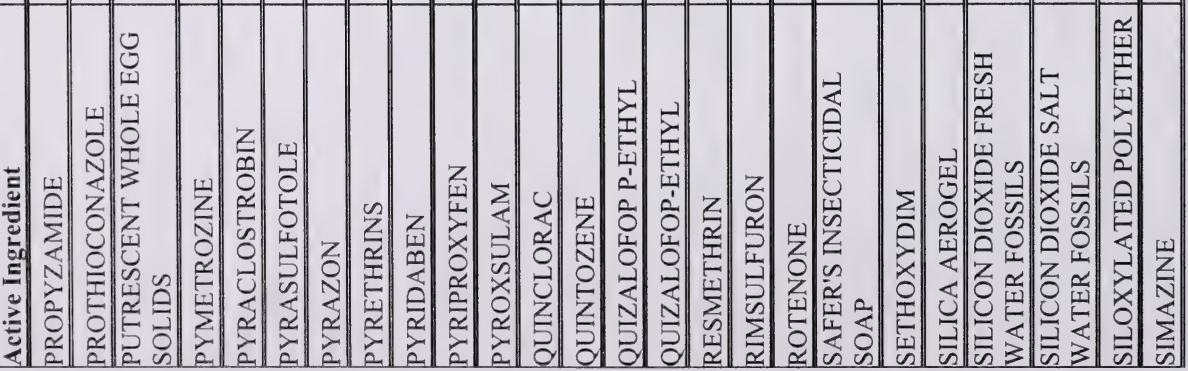




\begin{tabular}{|c|c|c|c|c|c|c|c|c|c|c|c|c|c|c|c|c|c|c|c|c|c|c|c|c|}
\hline$\stackrel{5}{\frac{\pi}{6}}$ & \begin{tabular}{|c||}
0 \\
$\dot{0}$ \\
$\infty$ \\
$\infty$
\end{tabular} & $\begin{array}{l}\infty \\
\stackrel{\infty}{m} \\
\sim\end{array}$ & $\begin{array}{c}+ \\
\infty \\
\infty \\
-\end{array}$ & 올 & $\tilde{o}$ & $\begin{array}{l}1 \\
-\infty\end{array}$ & $\exists$ & $\stackrel{?}{0}$ & $\begin{array}{l}\overline{0} \\
0\end{array}$ & ố & $\begin{array}{l}n \\
2 \\
2\end{array}$ & $\stackrel{+}{\circ}$ & in:|| & 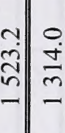 & $\stackrel{\substack{0 \\
\stackrel{+}{+}}}{\stackrel{\infty}{+}}$ & 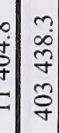 & ñ & $\mid$\begin{tabular}{c|}
0 \\
$a$ \\
$\dot{q}$ \\
$n$ \\
-1
\end{tabular} & 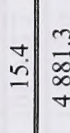 & 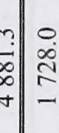 & \begin{tabular}{l|l}
0 \\
0 \\
0 \\
\end{tabular} & $\stackrel{+}{\infty}$ & $\frac{n}{2}$ & $\begin{array}{l}n \\
\frac{n}{n} \\
i n\end{array}$ \\
\hline 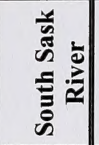 & वें & ते & & & & & & & & & $\begin{array}{l}0 \\
0 \\
0\end{array}$ & \begin{tabular}{l||}
0 \\
0
\end{tabular} & & \begin{tabular}{l|l}
$\vec{\gamma}$ \\
$\dot{\gamma}$
\end{tabular} & $\begin{array}{l}\stackrel{0}{\ddot{j}} \\
\ddot{2}\end{array}$ & 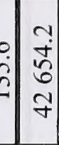 & & $\begin{array}{l}0 \\
m \\
0 \\
-1\end{array}$ & & 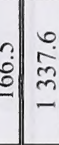 & :ُ & $?$ & & $\frac{9}{9}$ \\
\hline | & & $0^{\circ}$ & & & & & & & & & & & & $\begin{array}{l}0 \\
0 \\
0\end{array}$ & $\stackrel{+}{=}$ & 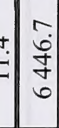 & & $\hat{o}$ & & & & ô. & & तु \\
\hline 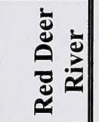 & & $\begin{array}{l}n \\
i \\
\end{array}$ & $\begin{array}{l}0 \\
0 \\
0\end{array}$ & & & & & & & & $\begin{array}{l}0 \\
\dot{b} \\
\dot{b}\end{array}$ & $\overrightarrow{0}$ & & 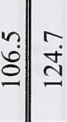 & $\stackrel{+}{I}$ & $\begin{array}{ll}v & n \\
\vdots & n \\
n & n \\
n & n \\
n & n\end{array}$ & & $\begin{array}{l}0 \\
\infty \\
0 \\
0 \\
\sim\end{array}$ & $\bar{r}$ & $\begin{array}{l}\dot{f} \\
\dot{0}\end{array}$ & $\stackrel{\circ}{\stackrel{0}{*}}$ & $\stackrel{\infty}{-}$ & & $\begin{array}{l}0 \\
\dot{y} \\
\dot{f}\end{array}$ \\
\hline 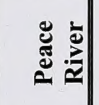 & & $\hat{\tilde{n}}$ & $\stackrel{?}{=}$ & & & & & & & & & o. & & 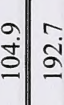 & $\ddot{\infty}$ & 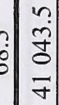 & $\mid \begin{array}{l}+ \\
\infty \\
m\end{array}$ & $\begin{array}{l}n \\
6 \\
6 \\
0\end{array}$ & స్ & 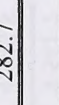 & & $\hat{0}$ & & $\underset{\substack{\infty \\
\infty}}{\stackrel{2}{2}}$ \\
\hline 矛 & $\begin{array}{c}a \\
\dot{b} \\
\triangleright\end{array}$ & oे & $\stackrel{-}{-}$ & & & & & $\stackrel{9}{\sim}$ & & & $\stackrel{?}{6}$ & ô. & & $\frac{0}{m}$ & $\stackrel{+}{\check{\pi}}$ & $=\left[\begin{array}{c}q \\
\tilde{m} \\
\tilde{q} \\
\Xi\end{array}\right.$ & : & $\begin{array}{l}9 \\
\text { ¿े } \\
0 \\
m\end{array}$ & & 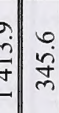 & 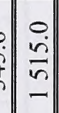 & $=$ & $\frac{r}{0}$ & $\begin{array}{l}\sim \\
\dot{0} \\
2 \\
\sigma\end{array}$ \\
\hline 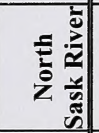 & & 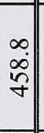 & $\begin{array}{l}0 \\
\text { n். }\end{array}$ & & & & & & & & $\stackrel{-}{-}$ & $\overline{0}$ & & 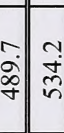 & 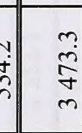 & 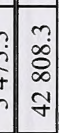 & ?ִ.|| & $\underset{\sim}{\stackrel{N}{\sim}}$ & 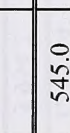 & صُ. & & $\stackrel{\sim}{\sim}$ & $\stackrel{\infty}{-}$ & $\begin{array}{l}\infty \\
\mathbb{j} \\
0 \\
0\end{array}$ \\
\hline 美豆 & & & & & & & & & & & & & & & & $\begin{array}{l}0 \\
0 \\
0 \\
+ \\
0\end{array}$ & & \begin{tabular}{l|l}
$\infty$ \\
$\dot{O}$ \\
$=$
\end{tabular} & $\stackrel{m}{\simeq}$ & $\stackrel{?}{-2}$ & & & & הู \\
\hline 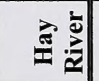 & & & & & & & & & & & & & & & & & & & & & & & & \\
\hline 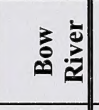 & & 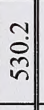 & $\begin{array}{l}0 \\
\dot{\infty} \\
\infty\end{array}$ & & & 우. & & & & & $\begin{array}{l}0 \\
\dot{\jmath}\end{array}$ & ְ.| & & $=\stackrel{n}{=}$ & $\begin{array}{l}\text { ․ } \\
0 \\
0 \\
m\end{array}$ & 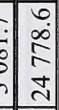 & $\therefore$ & à & $\frac{g}{\dot{J}}$ & : & $\stackrel{\circ}{\circ}$ & $\stackrel{+}{\infty}$ & & $\begin{array}{l}0 \\
\grave{\hat{~}}\end{array}$ \\
\hline 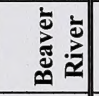 & & $\vec{\infty}$ & $\cong$ & & & & & & & & & & & $\stackrel{\sim}{\sim}$ & $\stackrel{ \pm}{=}$ & 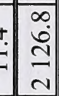 & & ㅇ. & $\stackrel{+}{ \pm}$ & $\stackrel{+}{\dot{u}}$ & & $\stackrel{1}{0}$ & & $\begin{array}{l}0 \\
\grave{\Xi}\end{array}$ \\
\hline 总京 & & $\begin{array}{l}\sim \\
\Xi \\
=\end{array}$ & $\begin{array}{l}\infty \\
i\end{array}$ & & & & & & & & \begin{tabular}{l|l|}
$\infty$ & \\
$\infty$ & \\
$\infty$ & \\
$n$ &
\end{tabular} & $\begin{array}{l}2 \\
\tilde{0} \\
0\end{array}$ & & 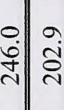 & : & 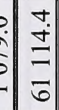 & & $\begin{array}{l}\overrightarrow{1} \\
\infty \\
\infty \\
0 \\
\sim\end{array}$ & $\begin{array}{l}\text { O } \\
\text { ב }\end{array}$ & : & & \begin{tabular}{l||}
0 \\
0 \\
0
\end{tabular} & & ڤ̆. \\
\hline 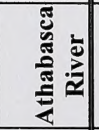 & & ?̧: & $\begin{array}{l}\vec{\infty} \\
\stackrel{\infty}{0}\end{array}$ & & & & & & & & & $\begin{array}{l}\tilde{0} \\
0 \\
0\end{array}$ & & 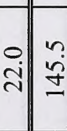 & लై & $\hat{i}$ & $\begin{array}{l}n \\
\vdots \\
3 \\
0\end{array}$ & 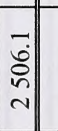 & $\begin{array}{l}0 \\
\infty \\
\infty \\
+\end{array}$ & o. & & $\hat{o}$ & & 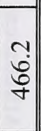 \\
\hline 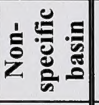 & & $\stackrel{0}{\mathrm{i}}$ & $\stackrel{\circ}{\circ}$ & ㅇ. & $\stackrel{\text { ֻ̃ }}{0}$ & $\stackrel{\infty}{=}$ & 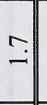 & $\stackrel{+}{\mathrm{i}}$ & $\begin{array}{l}0 \\
0 \\
0\end{array}$ & $\begin{array}{c}1 \\
0 \\
0\end{array}$ & $\stackrel{+}{\circ}$ & ¿্. & & 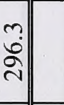 & ֻें & 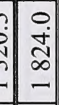 & 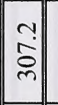 & & 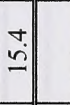 & $\stackrel{\sim}{=}$ & & $\stackrel{?}{0}$ & & $\begin{array}{l}0 \\
\text { ते }\end{array}$ \\
\hline 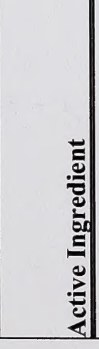 & 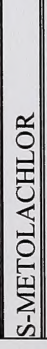 & 空 & 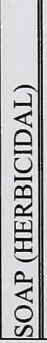 & 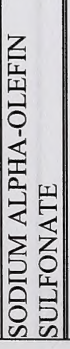 & 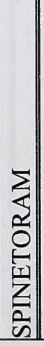 & 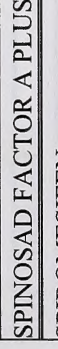 & 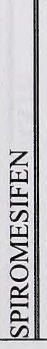 & 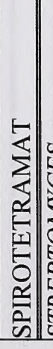 & 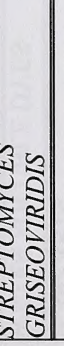 & 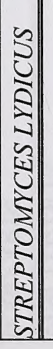 & . & 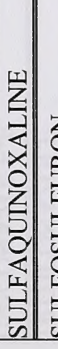 & 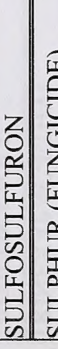 & 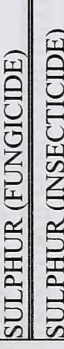 & 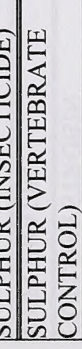 & 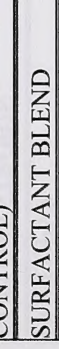 & 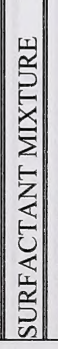 & 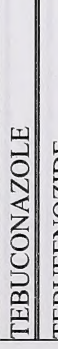 & 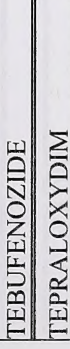 & 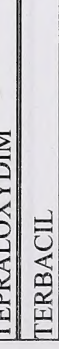 & 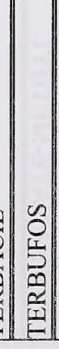 & 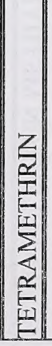 & 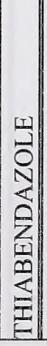 & 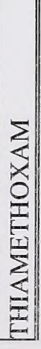 \\
\hline
\end{tabular}




\begin{tabular}{|c|c|c|c|c|c|c|c|c|c|c|c|c|c|c|c|c|c|c|c|c|c|c|}
\hline อี & 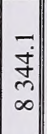 & $\mid \begin{array}{c}a \\
\dot{d} \\
0 \\
-1\end{array}$ & $\left|\begin{array}{l|}\infty \\
0 \\
\infty \\
0 \\
0 \\
r\end{array}\right|$ & $\begin{array}{l}a \\
\text { dे } \\
a \\
\text { f. }\end{array}$ & 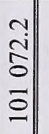 & $\begin{array}{l}n \\
z \\
z\end{array}$ & 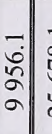 & 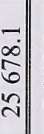 & \begin{tabular}{l|l}
0 & \\
$i$ & \\
$\delta$ & \\
& \\
&
\end{tabular} & 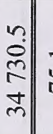 & ä & i. & $\begin{array}{l}\mathfrak{y} \\
\mathfrak{s} \\
m \\
m\end{array}$ & 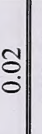 & \begin{tabular}{l||l|}
0 \\
$\vdots$ \\
$\sigma$ \\
$\sigma$
\end{tabular} & & $\vec{m}$ & $\begin{array}{l}m \\
\hat{s} \\
0\end{array}$ & ñ & ?ֶ. & $\stackrel{n}{n}$ & 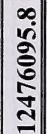 \\
\hline 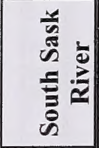 & 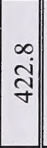 & $\mid$\begin{tabular}{c||}
9 \\
0 \\
0 \\
$m$
\end{tabular} & $\begin{array}{l}? \\
\\
\end{array}$ & $\begin{array}{l}0 \\
\hat{n} \\
\alpha \\
\alpha\end{array}$ & 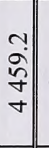 & & 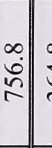 & 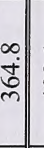 & के & 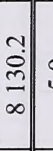 & के & & 일 & & 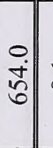 & & & $\begin{array}{l}? \\
? \\
?\end{array}$ & त̂ & & \begin{tabular}{l||} 
\\
$\infty$ \\
$\dot{r}$
\end{tabular} & گ̃ \\
\hline 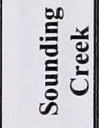 & ते| & $\dot{r}$ & के & 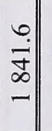 & $\begin{array}{l}\text { în } \\
\text { ñ } \\
-1\end{array}$ & & 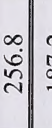 & 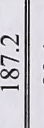 & $\overline{2}$ & 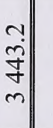 & & & 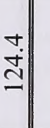 & & & & & בُ & & & $\stackrel{-}{-}$ & $\begin{array}{l}\infty \\
\varrho \\
\alpha \\
\alpha \\
\tilde{\sigma}\end{array}$ \\
\hline 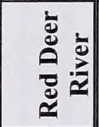 & 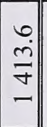 & - & 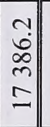 & 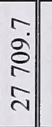 & 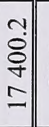 & $\stackrel{\infty}{\infty}$ & 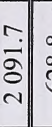 & 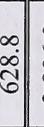 & \begin{tabular}{l||l}
0 \\
$\dot{b}$ \\
$\vdots$ \\
\end{tabular} & 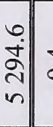 & $\dot{\leftrightarrow}$ & & 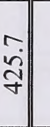 & & 它 & $\overrightarrow{0}$ & & 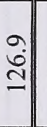 & $\frac{a}{m}$ & $\stackrel{t}{0}$ & $\begin{array}{l}\infty \\
+ \\
\sim\end{array}$ & $\begin{array}{l}0 \\
0 \\
y \\
y \\
y\end{array}$ \\
\hline 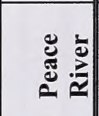 & 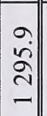 & $\stackrel{?}{=}$ & $\begin{array}{l}n \\
\bar{D} \\
i \\
n\end{array}$ & \begin{tabular}{l|l||}
$\infty$ \\
0 \\
0 \\
$\sigma$ \\
$\sigma$
\end{tabular} & \begin{tabular}{l||}
0 \\
0 \\
0 \\
0 \\
0
\end{tabular} & & $\begin{array}{l}n \\
\\
=\end{array}$ & \begin{tabular}{l|l}
\multirow{2}{*}{} \\
$m$ \\
$m$ \\
-
\end{tabular} & \begin{tabular}{l|l}
0 \\
$\dot{0}$ \\
-
\end{tabular} & - & & & \begin{tabular}{l||}
0 \\
$\dot{a}$
\end{tabular} & & 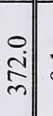 & $\overrightarrow{0}$ & & $\frac{\mathrm{m}}{\mathrm{m}}$ & iे & $\stackrel{\sim}{\sim}$ & $\because$ & 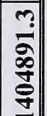 \\
\hline 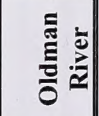 & $\begin{array}{l}\stackrel{+}{\mathrm{d}} \\
\mathrm{q}\end{array}$ & के & $\begin{array}{l}\stackrel{\sim}{n} \\
\stackrel{m}{n} \\
\end{array}$ & \begin{tabular}{l|}
$n$ \\
$i$ \\
$\delta$ \\
2 \\
$n$
\end{tabular} & 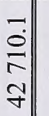 & & 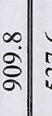 & 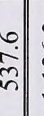 & 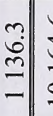 & 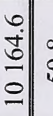 & $\begin{array}{l}\infty \\
\text { n̊. }\end{array}$ & & 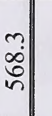 & & $\begin{array}{l}\stackrel{ \pm}{a} \\
\stackrel{2}{=}\end{array}$ & $\overrightarrow{0}$ & & 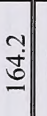 & $\stackrel{\circ}{-}$ & $\stackrel{0}{-}$ & $\stackrel{?}{2}$ & $\frac{5}{5}$ \\
\hline 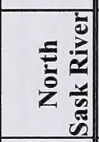 & 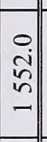 & ה̃ & 它 & \begin{tabular}{l|}
+ \\
$\dot{ \pm}$ \\
$\vdots$ \\
$\beth$
\end{tabular} & 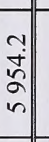 & & 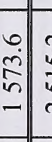 & 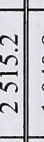 & 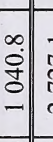 & 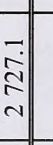 & & & $\vec{d}$ & & $\begin{array}{l}0 \\
\stackrel{0}{0} \\
\end{array}$ & 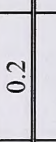 & & $\frac{0}{\dot{a}}$ & $\begin{array}{l}n \\
\tilde{n} \\
\tilde{n}\end{array}$ & $\begin{array}{l}0 \\
\stackrel{0}{2}\end{array}$ & $\hat{0}$ & है \\
\hline 兰㐫 & & & $\begin{array}{l}\hat{\delta} \\
\tilde{\delta} \\
n\end{array}$ & \begin{tabular}{l|l|}
$\infty$ & \\
$\infty$ \\
$\infty$ \\
$\infty$
\end{tabular} & $\begin{array}{l}n \\
0 \\
0 \\
n\end{array}$ & & $\begin{array}{l}\infty \\
\stackrel{+}{+}\end{array}$ & & ֶָ. & c.t. & & & & & & $\overline{0}$ & & & & & & 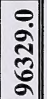 \\
\hline$\stackrel{d}{\pi}$ & & & & & & & & & & & & & & & & & & & & & & \\
\hline 它 & लें & $\frac{\nabla}{\dot{n}}$ & $\begin{array}{l}0 \\
0 \\
\tilde{n} \\
a \\
a\end{array}$ & 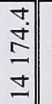 & $\begin{array}{l}- \\
\hat{n} \\
\infty \\
\infty\end{array}$ & & \begin{tabular}{l|l}
0 \\
$\dot{0}$ \\
&
\end{tabular} & \begin{tabular}{l|l||}
0 \\
\\
\end{tabular} & $\begin{array}{l}+ \\
\dot{0} \\
\dot{n}\end{array}$ & 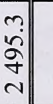 & & $\stackrel{i}{i}$ & $\begin{array}{l}\infty \\
\stackrel{+}{+}\end{array}$ & & 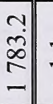 & $\Rightarrow$ & $\overrightarrow{\mathrm{m}}$ & $\begin{array}{l}\dot{t} \\
\dot{8}\end{array}$ & $\hat{\mathrm{I}}$ & $\stackrel{0}{-}$ & - & $\frac{1}{8}$ \\
\hline 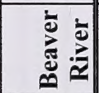 & $\begin{array}{c}+ \\
\text { aे }\end{array}$ & $\stackrel{\nabla}{0}$ & $\begin{array}{l}\infty \\
\dot{j} \\
\end{array}$ & \begin{tabular}{l|l|}
$\infty$ \\
$\dot{+}$ \\
$\stackrel{0}{0}$ \\
-
\end{tabular} & & & 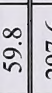 & $\begin{array}{l}0 \\
\text { iे }\end{array}$ & $\begin{array}{l}\infty \\
\text { తi }\end{array}$ & & & & $\begin{array}{l}0 \\
0 \\
i\end{array}$ & & & $\begin{array}{c}0 \\
0 \\
0\end{array}$ & & ָี & $\exists$ & & & \\
\hline 竧 & $\begin{array}{l}m \\
\dot{0} \\
\infty \\
-\end{array}$ & $\stackrel{\infty}{\circ}$ & \begin{tabular}{l|}
- \\
0 \\
$\infty$ \\
- \\
-
\end{tabular} & $\begin{array}{l}7 \\
\mathbf{i} \\
8 \\
0 \\
0\end{array}$ & \begin{tabular}{l|l}
$\vec{a}$ \\
$\vec{\sigma}$ \\
$\stackrel{\sigma}{=}$
\end{tabular} & $\therefore$ & 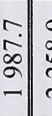 & \begin{tabular}{l||l}
$a$ & \\
$\infty$ & \\
& \\
$\mathrm{v}$ &
\end{tabular} & 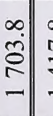 & \begin{tabular}{l}
$\infty$ \\
\multirow{\sigma}{*}{} \\
-
\end{tabular} & & & & & $\begin{array}{l}\infty \\
\text { ஸे } \\
\text { n. }\end{array}$ & ㅇ. & & in & $\stackrel{n}{2}$ & ભૈ. & $\because$ & ? \\
\hline 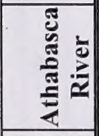 & $\begin{array}{l}\infty \\
\infty \\
\vdots \\
\end{array}$ & 0 & 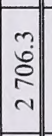 & $\begin{array}{l}\infty \\
i \\
\tilde{n} \\
\sim\end{array}$ & 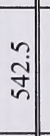 & & 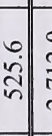 & 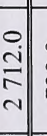 & $\begin{array}{l}0 \\
\stackrel{0}{0} \\
\end{array}$ & $\stackrel{\overbrace{}}{i}$ & & & $\begin{array}{l}n \\
\text { ñ }\end{array}$ & & ָָ & $\overrightarrow{0}$ & & 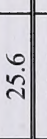 & $\begin{array}{l}0 \\
\text { ते }\end{array}$ & $\stackrel{t}{0}$ & $\begin{array}{l}n \\
n\end{array}$ & s \\
\hline 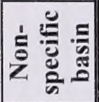 & & 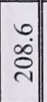 & 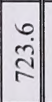 & & & & & กี & $\begin{array}{l}0 \\
\dot{c} \\
\dot{m}\end{array}$ & & & $\overrightarrow{0}$ & $\frac{1}{i}$ & & & & & $\begin{array}{l}0 \\
\text { in } \\
\text { in }\end{array}$ & & & & 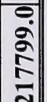 \\
\hline 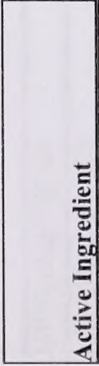 & 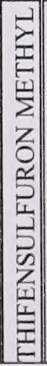 & 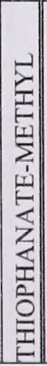 & $\frac{\Sigma}{\vdots}$ & 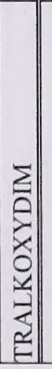 & 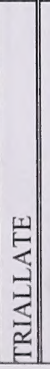 & 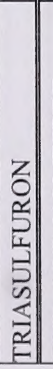 & 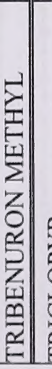 & 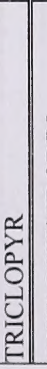 & 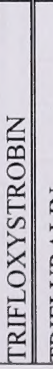 & 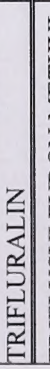 & 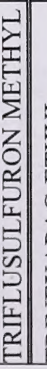 & 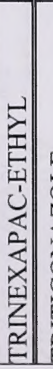 & 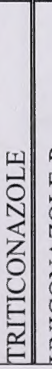 & 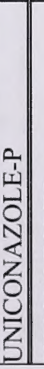 & 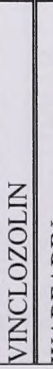 & 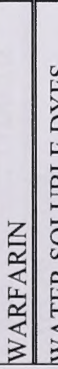 & 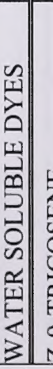 & 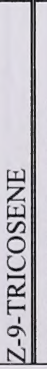 & 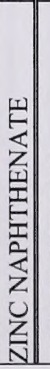 & 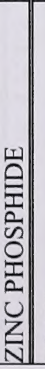 & $\frac{m}{\mathrm{~N}}$ & $\frac{5}{6}$ \\
\hline
\end{tabular}





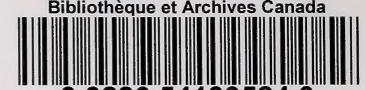

33286541395840 